University of Louisville

ThinkIR: The University of Louisville's Institutional Repository

Electronic Theses and Dissertations

1932

\title{
The influence of Spenser's Irish residence on the Faerie queene.
}

Ellen McDowell Davis

University of Louisville

Follow this and additional works at: https://ir.library.louisville.edu/etd

Part of the English Language and Literature Commons

\section{Recommended Citation}

Davis, Ellen McDowell, "The influence of Spenser's Irish residence on the Faerie queene." (1932).

Electronic Theses and Dissertations. Paper 1935.

https://doi.org/10.18297/etd/1935

This Master's Thesis is brought to you for free and open access by ThinkIR: The University of Louisville's Institutional Repository. It has been accepted for inclusion in Electronic Theses and Dissertations by an authorized administrator of ThinkIR: The University of Louisville's Institutional Repository. This title appears here courtesy of the author, who has retained all other copyrights. For more information, please contact thinkir@louisville.edu. 


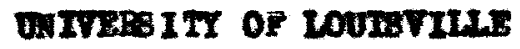

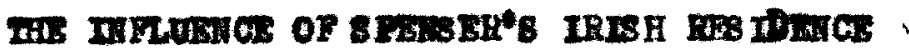

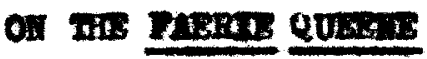

\author{
A DSecortation \\ 8wbitted to the Paowty

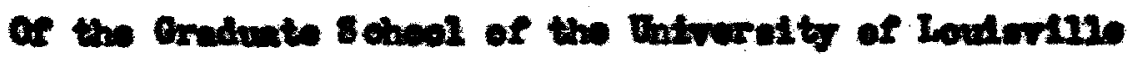 \\ In Pathal Pulfivmont of the \\ Benutromente for the Degree \\ or veter of ints
}

Dopitamt of Doghen

Bs

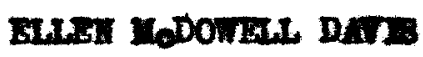

200 


\section{UHE UNWvessir LIBRARIES}

This PDF document is a scanned copy of a paper manuscript housed in the University of Louisville (UofL) Libraries. The quality of this reproduction is greatly dependent upon the condition of the original paper copy. Indistinct print and poor quality illustrations are a direct reflection of the quality of materials that are available for scanning. The UofL Libraries greatly appreciates any better copies that can be made available for replacement scans. 
Gupter I Intreduotion

Chapter II In InRivace of Iroland an the Politien Vien in the Berla Prant

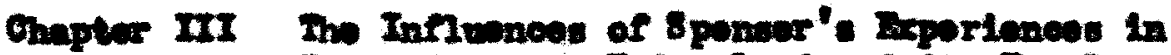
Iroland on his Patry land and Itu Pooplo

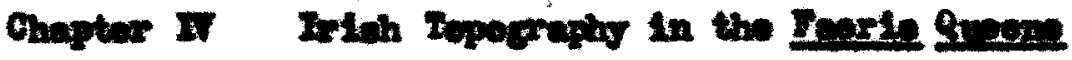

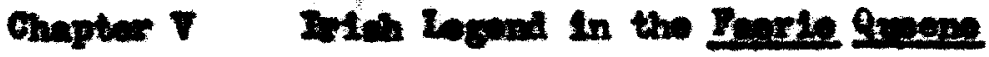

Chapter II Conolusten

Bb2letraty 
GHAPIER I

10m0003780: 
GAPTIR $\mathbf{z}$

\section{inmoDocmo:}

The doparture of Iponeer for Treland In 1600 as seoretary to Iord Arey of IIton, nowly appointed Lord Doputy of Irolend, wario a

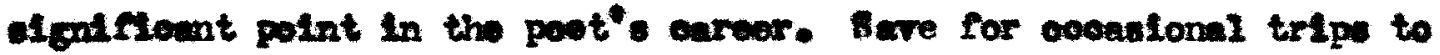

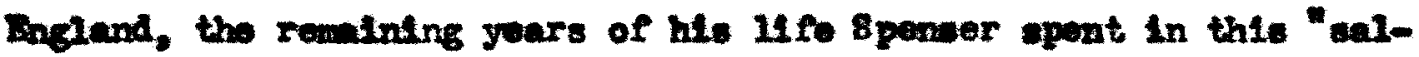

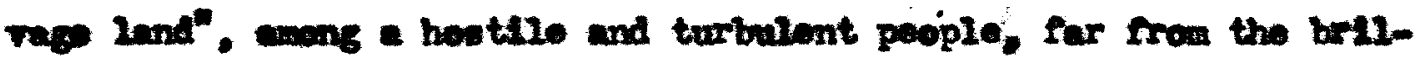

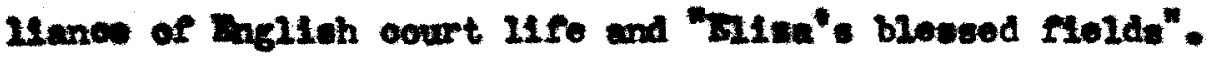

Ihe appointwont to eorviee in Ireland coew te hwo been a

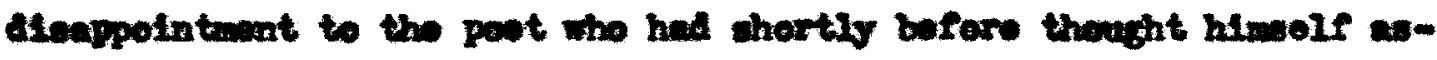
cured of an offieial carear in Bngland under the patrenage of lokoestor. In Botabor of the preading yoar he had copoeted to bo cont on a forelgn

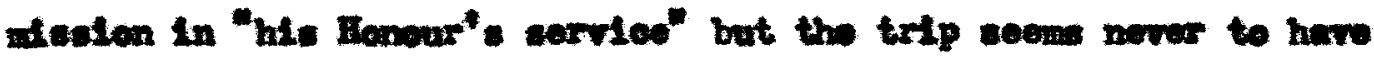

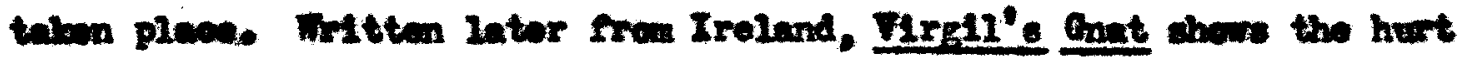

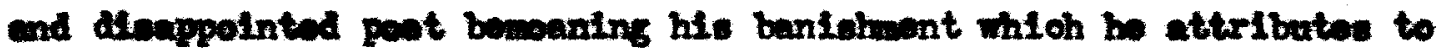

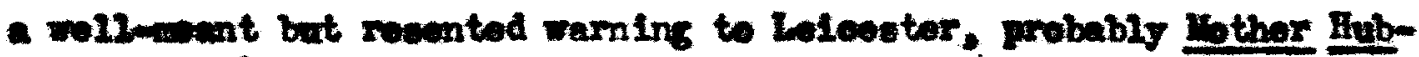
1 berd nis. in wites.

I eurriad en into mate milernoves,

Wasto Hilormose, awong Oywerian shades,

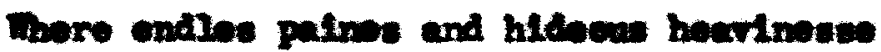

If round ebout w houpt in dariane glades."

(T. 0. $\operatorname{sesir2)}$

3

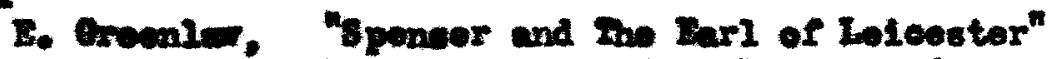

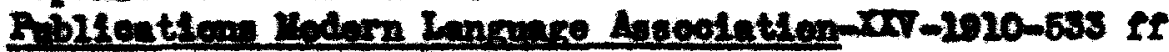




\section{2.}

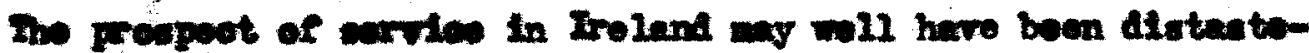
nil to the peot, for the country wes in flores rebellion agalnat hor

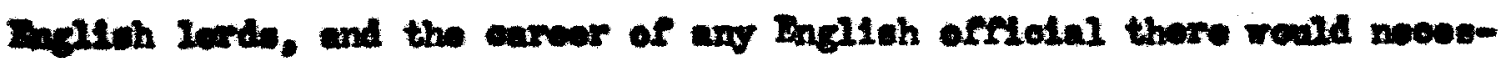

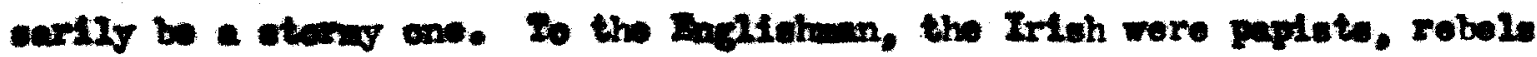

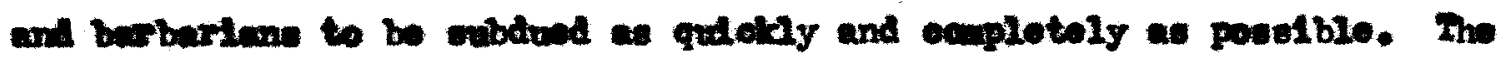
country me a wld land full of bege and forvots, the mors torreble ner

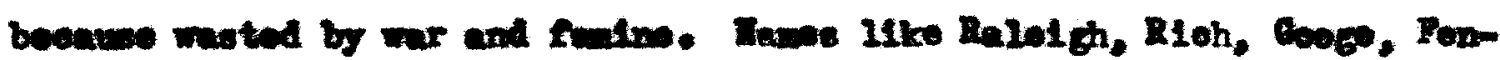

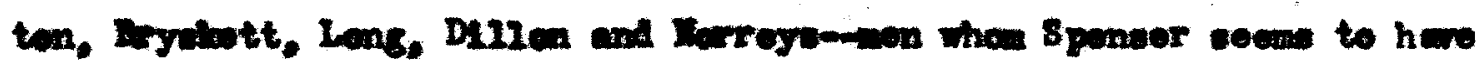

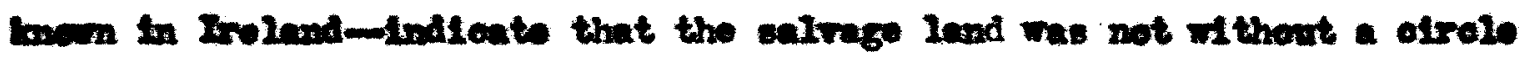

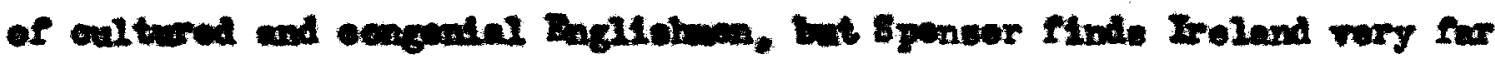

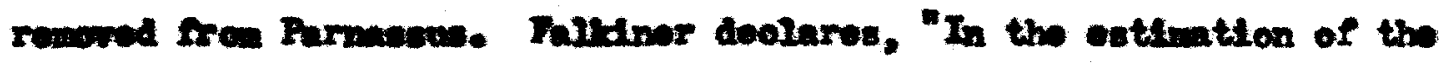

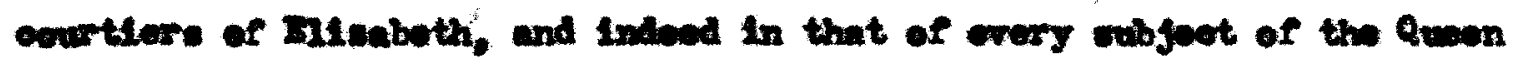

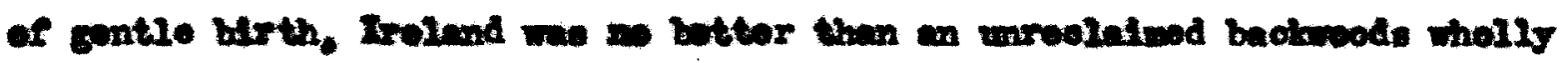

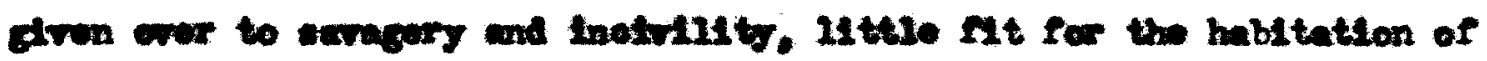
people of charwoter and refinoment, but to mioh in the laut rosort a

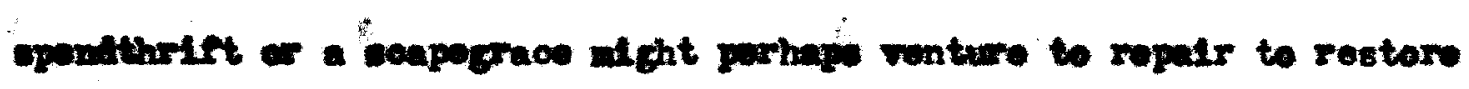

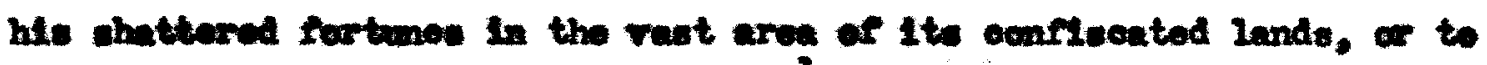
win roputation in 1te inoesesnt ware." It is encll wonder that 8 poneer felt himele a "right forlore" benlahod in "that mato".

It Is a elgalfioent hot that it was during the post'. Irieh

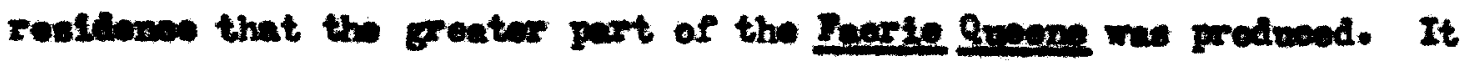
como cortaln that sponsor was oonetow that his wurrowalng had left

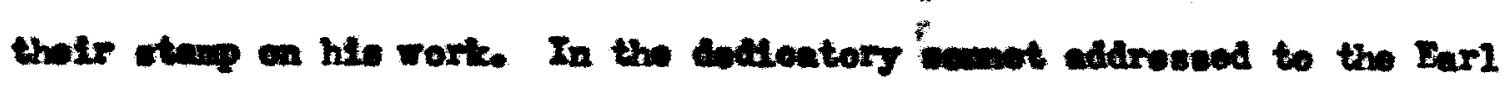
of Ormend ho mitos:

Dacelve mont noble lard a elmple tasto

1 4. C. Falliner, "Bponser in Irolend" 
of the wilde fruit, which enkrge land hath bred

whioh being through long ware laft elwont wasto

Wth butioh berbariowe is onerapreda:

And in so raire a lend as as bed,

lot on Purnagerse, nor ane Billow

Left for exeot have to be harbound

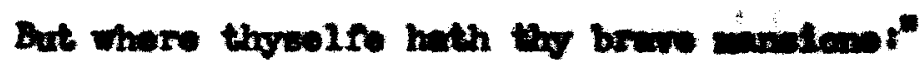

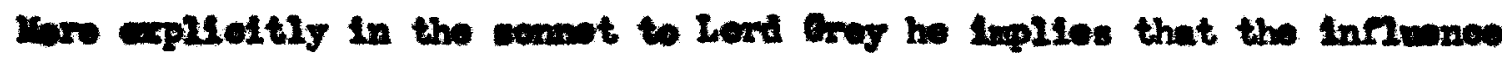
of the Inxd had boen harund when he refore to his poes as,

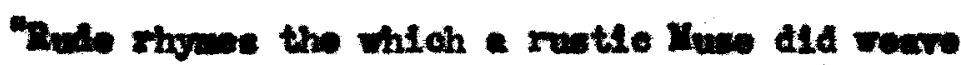

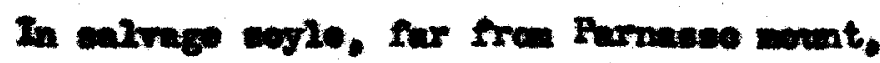

ind roughy wought in an mloerned Leaso"

sweh rorurwnese are alefteult to intorpot coevrately eince 1

they wo, a beenle suggests, wrely a renoetion of "the conventlonal proteotation of the peets for the nommose of thelr verses".

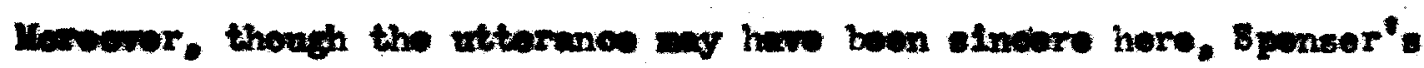

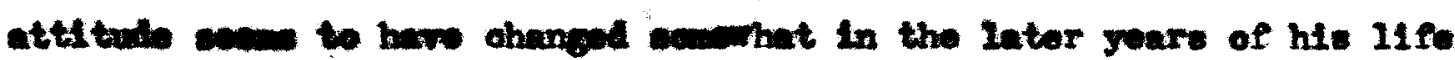

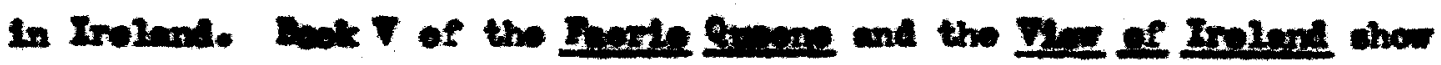
an action gond gentorest in the wifare of Ireland, and, with

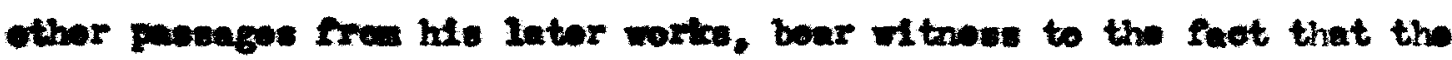
paot had foumd mooh to adudre and wonder at in the beauty of the lend wioh had beone his hem, and in the remanes and logend of Ite history.

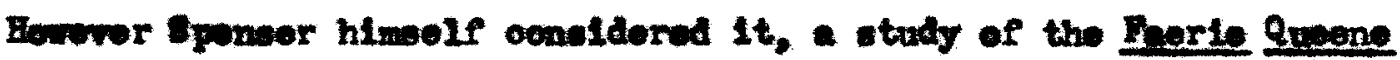
would Indiont that the Irish restdones was benofiolal rather then haraful to hle eontue. Dunden has said, "Io have a part in the ragged commencenth of Iroland appoared to sponser to be IIttle 1088 than 1 1. Gronler, "sponser and British Imporiallom" Iodarn Philolexy-x-1012-p 347 if 


\section{4.}

bentohwont. Irelend we to him a earrage colli got for one of hls toupor, selltalo ment have boen botter than the olowe thouldoring of the proses lulls, Fippling below hor aldors, whot have been more melcal than the valutinge of spoophantes the Irioh alr, tho IIghts and shaders. the bright vell of rain, the tender luminowonese of morning and oventing,

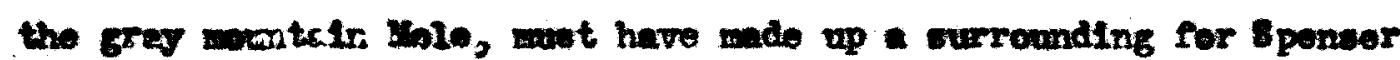
more open and rrosh than the ante chamber more importunats eudtore are be to matt."

Dr. 81goreon, an Irishuen, pats it more etrongly when ho saye, "Bpeneer oame to womand, oanght by the glamour of the Bal, gave we

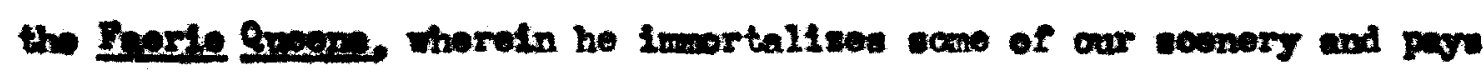
tribut to the enolent renow of our netton.ene..... It is notewrorthy that the exeat poen wich marked the revival of Bnglish letters after. Ohaveor was witten in Iroland. Crenting that 8 penser found modole in Arlosto and Fasso, pet if he had romeined in Londen, be might nover have rigen ebove the standerd of the Palnoompotsen....... Probably nothing saved sponeer but his Imorelon in Irish mature, whioh hls verse so falthrully rofnotis. Not oniy are the matoriel beatiles of ow oountry, moventaine, wood and rivers, wirrored there, but its epiritual worid

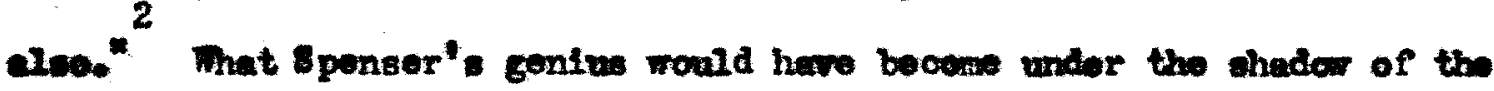
ceurt oun be anly a subjoet for conjocture. That ho did beconse in the onvironwent in whioh be was plaoed wo mo discover, at loast in part, from a etudy of the work he produced during the Irloh poriod. It is the

1

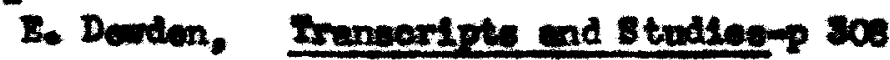

2 Q. 51gervon-4n-Irleh Ltorature- $\pi-4 x$ 
purpoes of this study to show that the staup of spones"s Irish wr-

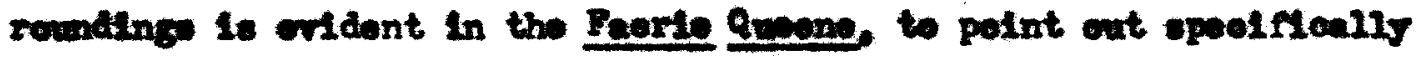
the Influmee of Iroland on the peot's ooneoption of his wubjoct and

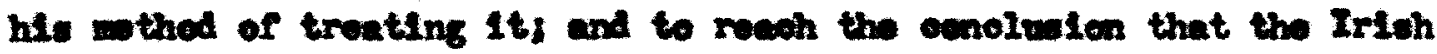
rooldanoe, wo fror from being dotrimontal to sponecr, wa rathor of definste vine in Intentifying and vitallsing the quality of his gonive. The poet's Imgination mas ought by the beauty, the torror and the rowance of the plaos where he found woch in hle ourroundinge that was akin in epirit and appoerance to the Falrymlend of his oplo, and tho

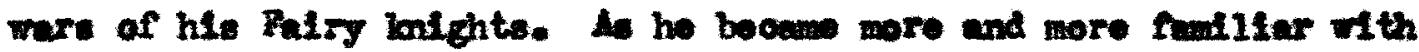
the coventry and its history, ho alluded to it ware freguently and more

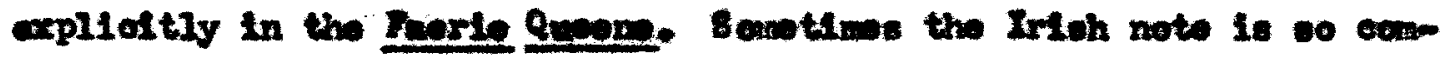
plotoly rwoed with othor olewents in 8 penser"s ow ininitable mumor, as to be almost Indlatinguishable, but, whell attempt to shor, man passages are unilatakbly Irish in insplration.

The echoes of the Irieh years seom to fall Into four groupe. Spenes's yours in goverment servioe naturally influonoed hls political Ideas and theorles of gorernment. If he had the sam Ideas before reaohing Irolend, his leter experlencos doveloped and Intensiffed them. In the Fearle Qneene wo have not only an allegorionl socount of a part of his offlotal servioe in Iroland, but a theory of government eot Porth.

The woond group is closely related. It ounoorns the refloo-

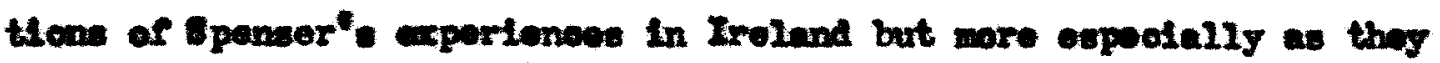
tond to color the platures of his inighte end their foes than in roIatien to a polition theory.

The third group deals of th speneer's use of Irtoh topography 


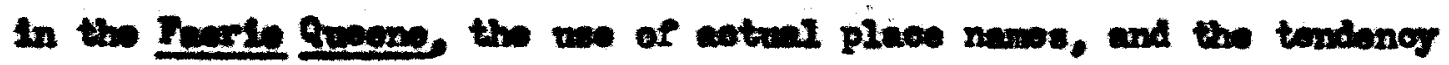

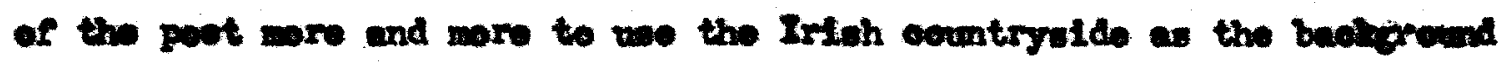
of his Tary-land.

The last group conetitutes the refleotsione of Irish literaturo, legend and foll lowe in the Peorte Qeoone. A soparate chapter AII be drroted to each of these alvisione. 
CHAPIER 2

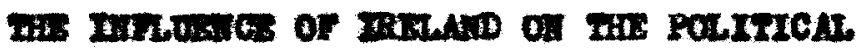

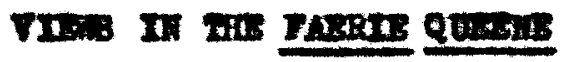




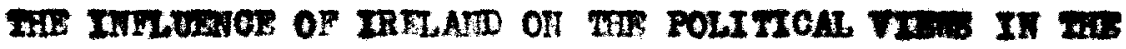

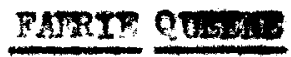

Book $V$ of the Pgerie Queene omteing tho most apparent alogory doaling ith sponser's personal exporienoes in Irolind. The date of Cempostion of Book $V$ is moertalin, but it is thought tiut it was begun perbapa about 1583 or 1684, Inspired by the doath of Lord orey in ovtober. $158 s^{1}$. In the porson of Ltegall, the poot ropresents Cres of the knight of sustiec and proseds into an elaborate cerenes of the Deputy and his gowermont. juetlyding before the world erey" ubending policy wich had mat woh bitter oriticlem in Dnglend. In ocmootion with this defones, spaneer wales platn his theory of the anty proper govermant for Ireiend.

The faot that spenger represents Groy as frtogall, the inight of dustioe. trained by lotraea hervelf whlo the livad among won, is in

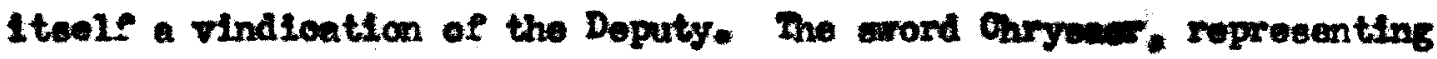

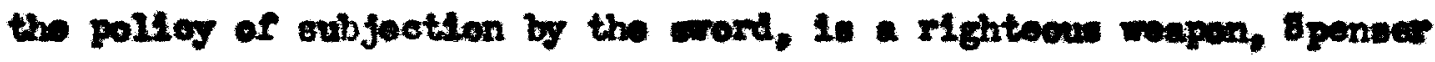
1mplises. Inoe Lstrese gave it to htw, and Jove himelf had wed it

$$
\text { In that great Nght }
$$

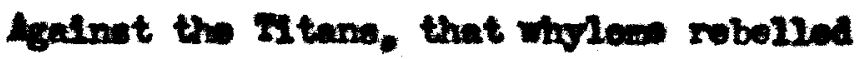
Calnst highat howrons"

Atraen left aleo hor cm groon Ralus, the Iren nen. ? 1. 6. Fandinar. Eponear in Irolana"

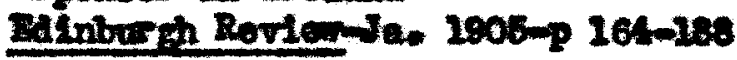




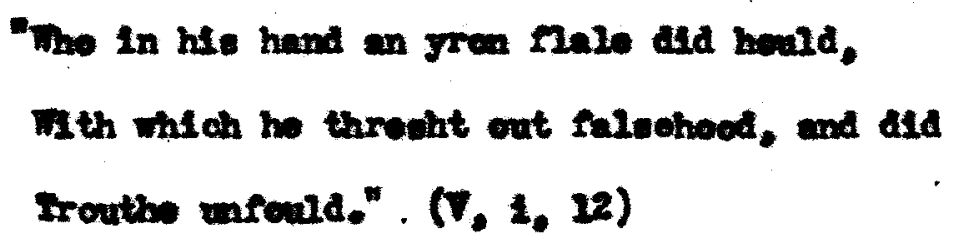

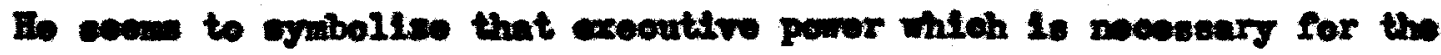
carrying out of the dearees of justios. and in the ease of Irolund this power whe milltary force.

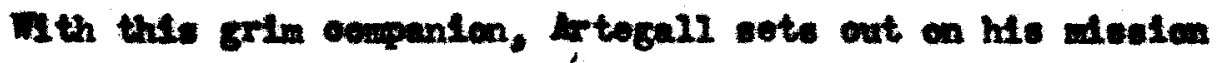

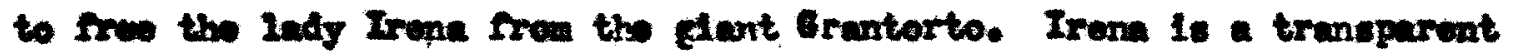

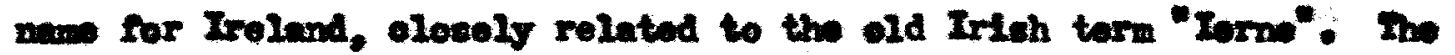
eleve carrospudenes to the Creok Irens, on of the Horne and geddeve of peace, Impllev that Iron is peoeful Irolend wom Artogull is to restore to hor I Ihtful heritage.

Atognil wote if th wny adventures before the final ocobat

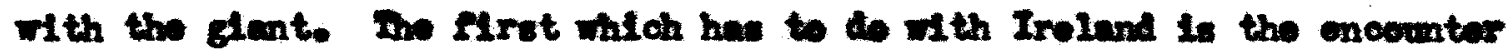

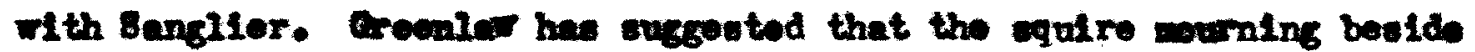

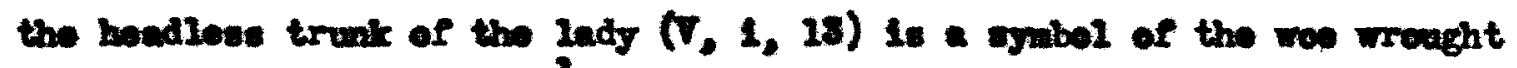

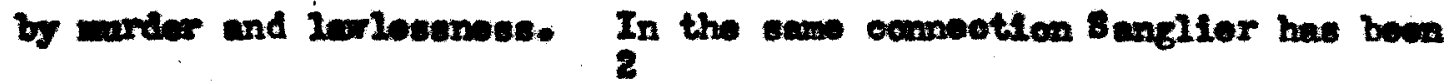

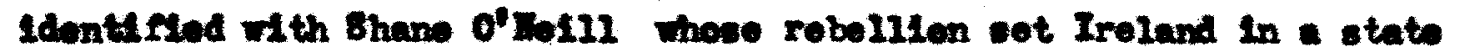
of tarwall and bleodohod whioh did not end with his lonth in 168\%. The olaughter had ecourred before Artegull's arrival, but the efroots had

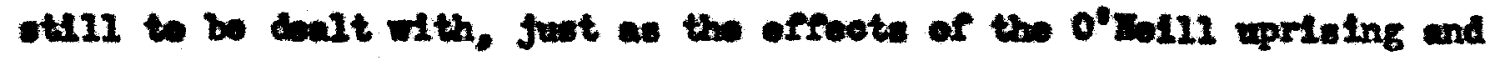

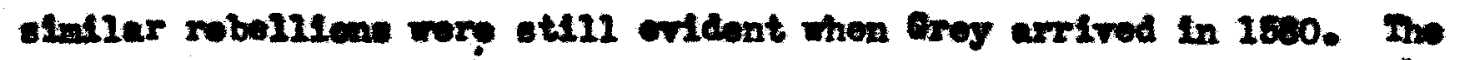

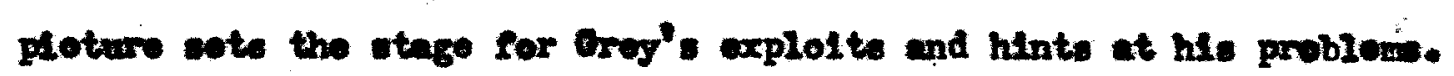
1

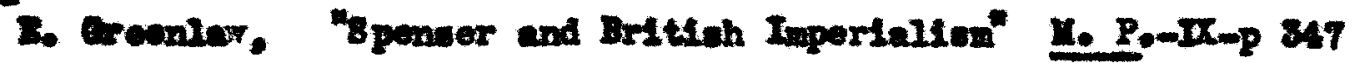

2

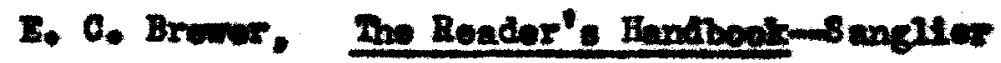




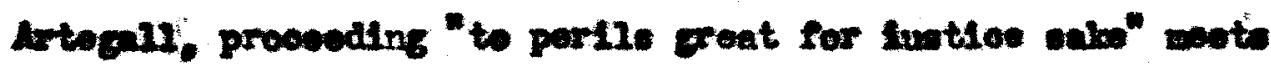

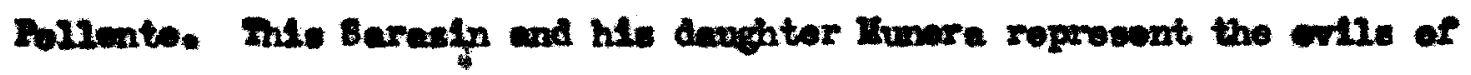
extartien and bribary in government with Brey had to doetroy before

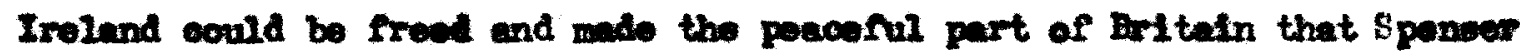
1

drownd. The etringent wothod are In harmany with the troatomt of Enantorto in oanto xil.

In cante ix. Artegall moets wth enother foe in tho form of Wlengin. Halle or Docelt. This enomy eoem to represent the wendering bande of Irtah rebels whom Orey had to trace to thatr baunte and subdw before Irelend could bo reotored to allegianoe to England. In the Ver

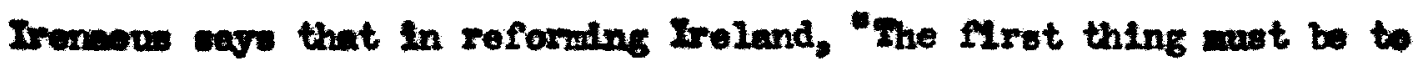
sond ower into that realm euch a stronge power of won, as that shall

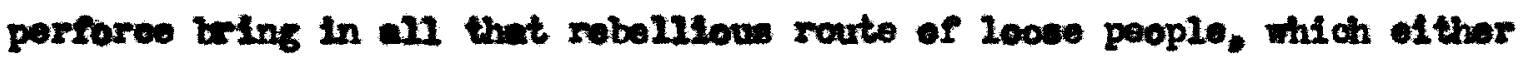

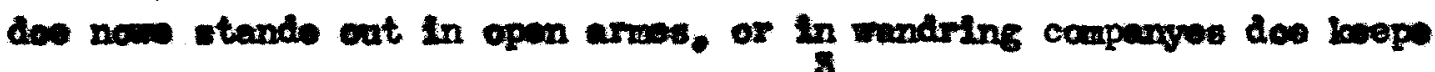
the roodes, epoyling the good oubject."

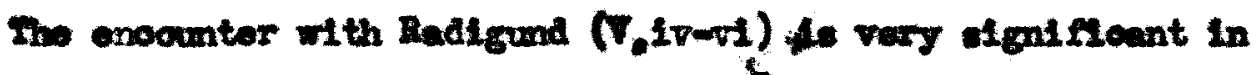

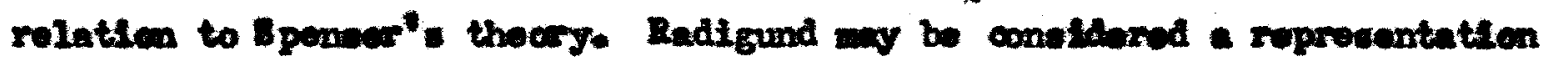

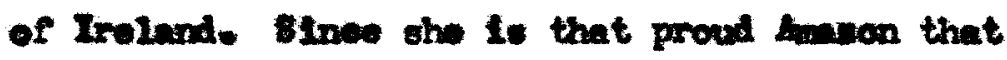

$$
\text { ala late dery }
$$

111 the brave Inighte that hold of Ialdenhead". the is not the poncoful Iron to be proteoted. but rather the Ireland 1 B. Exvariar, op. ofte, pes47-370 2

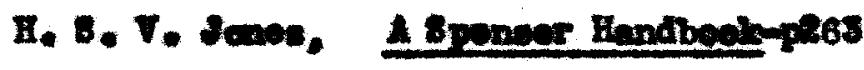

3

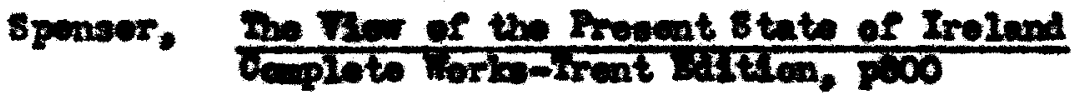


that is in arme agoinet Inglund. Hore was a foo that otood in the way of the reatoration of Irona, and Artegall's combet againet her begine wanrully enough. Madigand is oompuerod and lies at his moroy. He mlaces her holnet, and is suddenly arrested by her beecty.

- At sight thereof his orvel mindec hoart Bupleroed was with pittivil regard

That his sharpe sword he threw from him apart

Cursing hle hend that had that risage wara." $(7, \nabla, 13)$ The reoult is Irwodiate. Radigund rises, rodoubles her attats on the nor unarnod knight, and woon hes hIm in her powor. Arrayed in wown's weods he is wet to opinning-a sorry flgure indoed whess Britomart coses Ainally to reseve.

The bearing on the Irim question is importants Artegan". ruln is wrought by plty which speneor here conoelves of as a fatal new in the knight's oherecter, out of kooping with fratioe. It the othor extrome is over-everity. Porfect fustice steers a stralght coures between, and is therefore the golden mean. In dealing with rebellious people, where juatioe must be done and the fate of the dominien is at Etalo, a polloy whloh adul ts of pity is both woak and womantish and oen lead only to divaster. This is spenser's menting. In the ver of Ire-

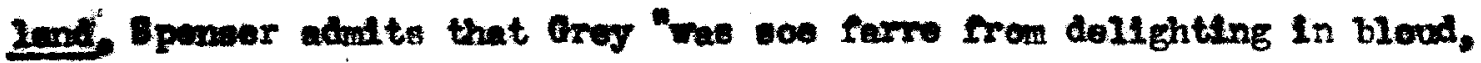
that oftentimes he surfered not just rengoance to fall where it was coserved and oven come of those whloh wore afterwardes his secusers had tasted to weh of his morcye, and were from the gallowe breught to

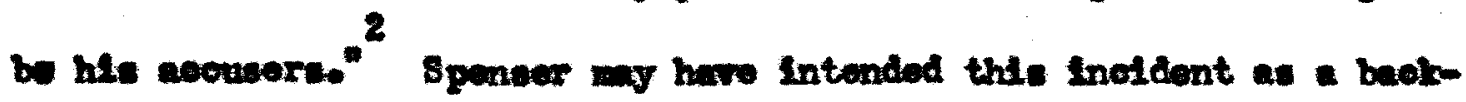

1 P. Benlog, Speaser in Irolund-p 142-142 
ground and a prolude to the Orentorto opteode, a jugtiflcation of

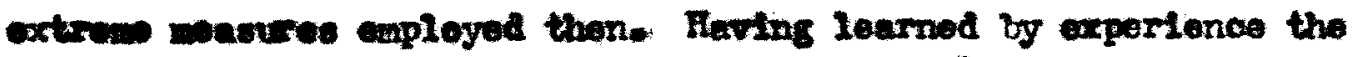
angers of allewing PIty to offoet mar pollotos, Brey was foroed to

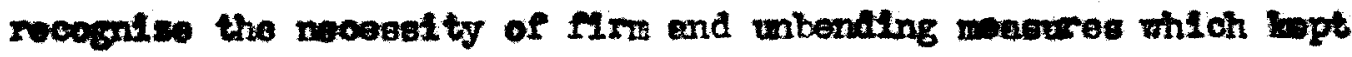
Justioe and the nocessity of Imperial donination elwnys in sight.

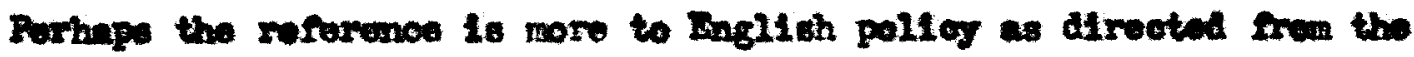
Inglish eourt then to the Doputy hinself. Mizabeth, veering avddom

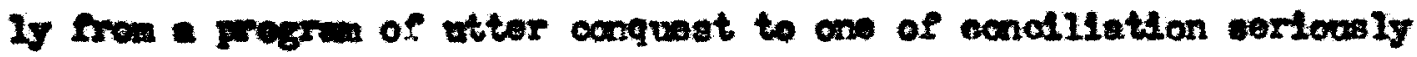
hindared tho Depaty in his work, ofton golng so far as to send pardone

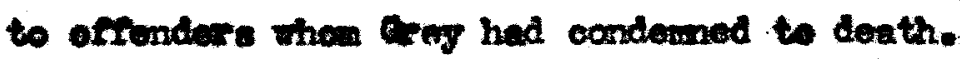

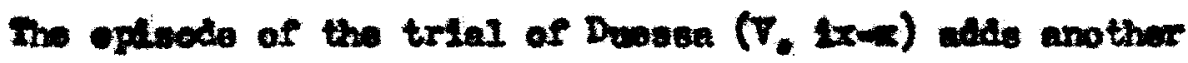
polnt. Wroills is torohed with plty for the acoused and weope at hor rate. Wheroupen spenser dieavureos upen the qrall ty of wercy.

"Por if that vortw be of wo grent might.

Whioh from fuet vordiot will for nothing stert,

But to preserve inviolated right,

Ort optlles the prinotpall, to save the pert;

So mach wore then 1s that of power and art,

Dhat soober to save the subject of har okd11.

Tet nover doth from doows of right dopart:

A. It is better proves to serve then opili, And better to roforrse, then to out off the ill."

Deretila ptitled Dwose and longed to save hor, but, realising that whe was werthy of death, and "when strong oonstralnt did hor theroto onfores" she allowed the sentence to be weeuted, for, not owen for pity oould the "Irem deone of right dopart". Wroy, then, is a noceseary attributo

1

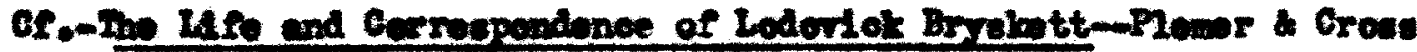
F. 18, 23, 35 for oontomporary eooevent. 


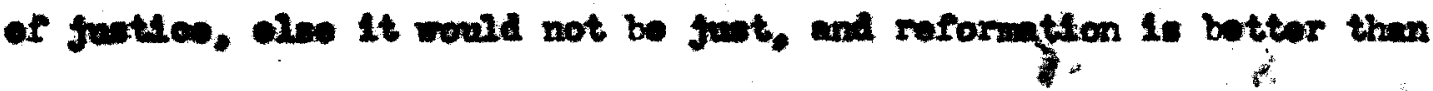
atorumation, but there are tirpe, enye sponeer, fhen reformation is

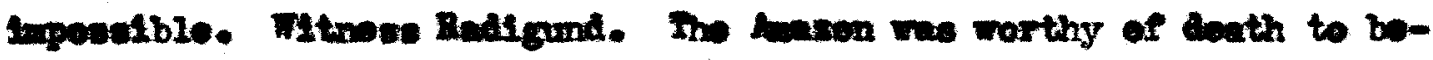
An Ith. When ppared she shows no gratitud but towe on the lentght

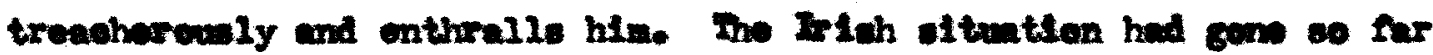
that subjection wo the only wothad pructical. end pity bad no part in that.

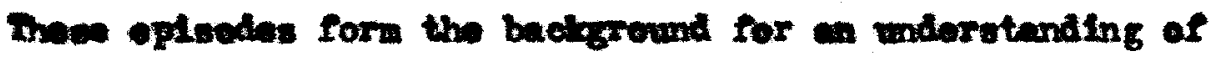

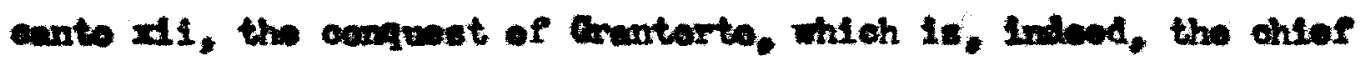
arganiont of the beck.

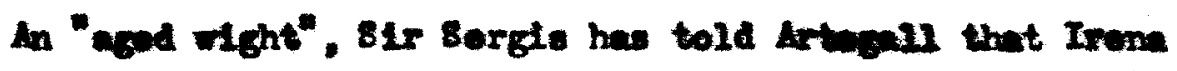
Nil be diled by the glent in ten day if a chapian doos not ir-

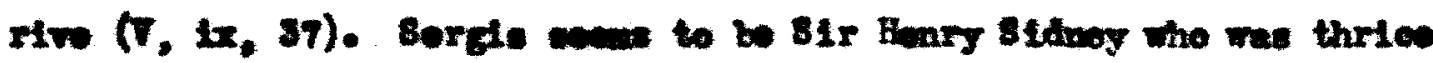

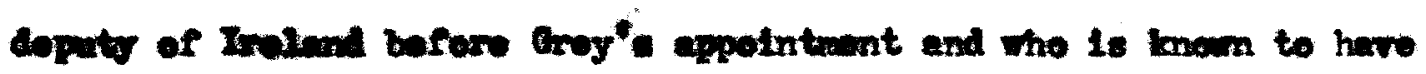

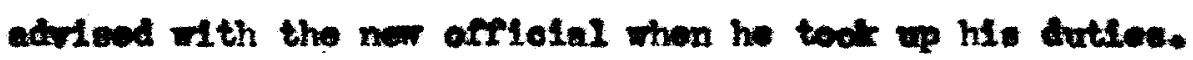

Artogall and the Iren page arrive at Grentorte' abode on the das ent for the weoution. In eingle combat the lnight of Justion

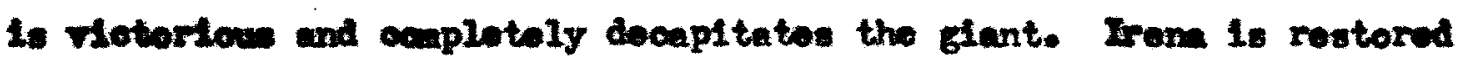
to ha thrane. All trattors are slain and iniw is holping Artegall wot tho lingdow in ordor when the knight is reoulled to Ferie court. On the wey. Imy, Dotraetion and the Blatant Bast woot Min and ahamAnly abue him.

Bore, in thinly wilea allegory, is the etery of Orey's ca-

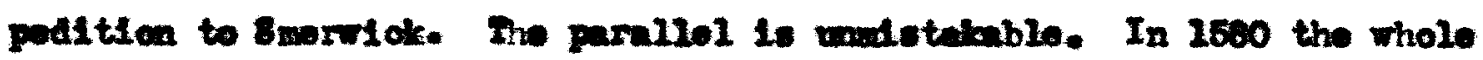
of Iroland wa in a tarmofl. In the wouth, the Larl of Dosond and his brether Jom wore jolwed by Tiocomt Baltinglas and Fiagh Haefugh O'Byme who had reoently defouted eros at Glomalure. Dr. Hoholas 8awodere. the papal legate, we encouraging thom with now of aid from 
the continent. Both the Pope and Plilip II of Spain were ratohins Ireland"s otrugele for freedon and were anxlous to holp her in order to gain a noarby foothold from fhich to attack Mngland. Grantorto has been called both the Pope and Pillip. lut as Jones declares. Or. Gang" Identification of Erantorto ith the Pope ohould be preferred to the traditional Identification with Filip $I_{b}$ becave It was the Pope rather than Philip that took an eotive part in Irish aptairs. It was he tho in 1577 gave Janes Fitzaurioe a comiselon to conquer the country, who in 1579 bestemed ecnsecrated banner upen the eanil expedition houded by Mtemauriee and hlo om legate Dr. Bamders! and It wes he mo in 1580 despatched the 800 Italians ard spentards" to 8 mermiek.

On Howenter 8. Oroy merched against the Fort del Ore whith mas Atuatod on a narros strip of lend in Barrici Bay. Hodged in between the Baglioh Fleot on tho one elde and the Baglish troops on the other, the rebels wore brought to surronder witin tho days. Epenserdoolares that he was "as noero then as any" won the leader of the Imvadere oano to sue for terms. Fhereupon the beyd Colonel did abeolutely yeold himselfe and the forte, win. all therin, and orxved only marcye. Which it being not thought good to sherre them, both for daunger of themselves, if, belng saved, they should afterrarten josm It the IrLh, whe mere woh exboldened by thoge forrayne suecours, and weo putt in hope of more ore long: there was noo othor way but to wals that horte ond of ther whioh was ado." The end. Canden 1

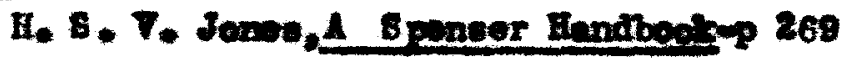


relates. wes "aganct the will of the Dopaty who wept thereat, that the leatere thould be saved and all the reat pat to the oword for an caxaple,

and thet the Irish should bo hanged, wloh was presently dooo." $81 x$ humdrod were slain that day, but in the annals of Ireland oven ach a defeat vas not the end of the trouble as the allegory Inplies.

It was this sleughter whioh caveod Inv and Dotraetion and - Iander to attack Groy. espeolelly on his return to Dhgland. The hag abuse is Iike that which froy met from all sidest

$$
\text { - That ho had with umanily gulle }
$$

And foule abrelon both his honew blont, And that bright arord, his grord of Justioe lent, Hed steynod with reproahfull orveltie. In griltloese blood of wany en lnmocent:

4. for Orentarto, him with trencherio And traymes hering eurpris"d, he fouly did to ate."

$$
\text { (v. } x+14.40)
$$

Arog'e action at Bworrick cortainly doos not noot with

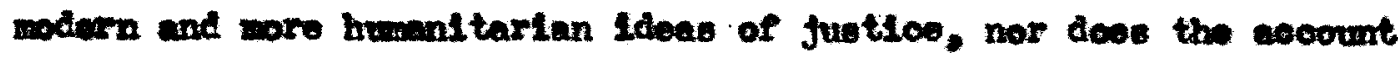

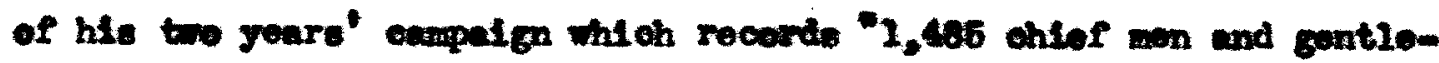
wan saln, not accounting those of weaner sort, nor yet excoutions by

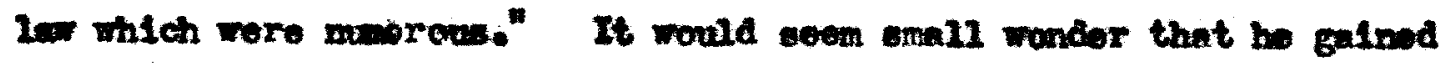

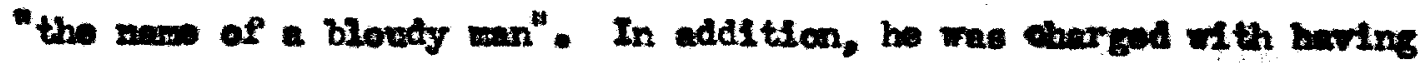

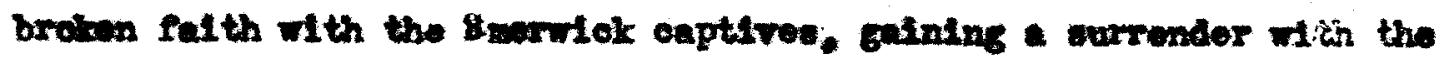
1 Willan Canden, Bertemie- rol. IV

2

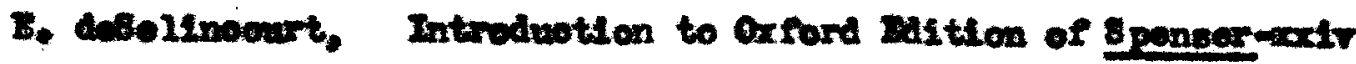


proadwe of 140, and thon kiling neerly all in the fort.

Eponser sofribe beth theee charges both oleverly and con-

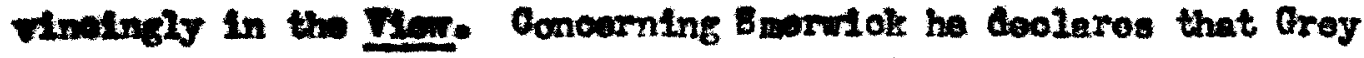

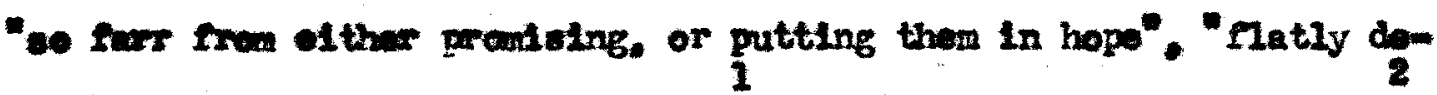
abled then axy hope from the eirst. Orey's statenent to the Qusen canevintns the afrulr asserts that ho gave then no promise and that they glelded "for 11 fo or ceath". Horeover. the roavons for the necagm It of the alaugter intch spenser sots dom, aro. If viened in the Ifght of the taoties of the lay, eound and orthodex enough. Inough onowaraged by the Fope and ocuntenenced by Filip, thry wore, as Epenser states. not Iertal enewtes-bat only adventurers. "The $\mathbf{8}$ panteh were logally pirates, who hed without valld comblasions ettrred up the natse Irlich to rolellion. Inglish advonturers in the sawe legel pom Ation on the Spanith maln, although froe from the adod impatation of Inelting to robellion, had been morcilessly elain. The only fault found by the Qwen was that the ouperior offloors had been sparod."

Eponeor's argunent, however. goos deeper than the justifloation of a timple expodition. A theory of government is underlying the wole defomes, for Grop' aduinistration is representativo of all the rot during these troabled yours. The problem was the eane. In the Vlex

$\mathbf{2}$ ves, p 006

2 D. W. Ouroh, Bponsermp $58-60$

3

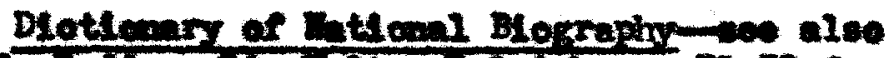

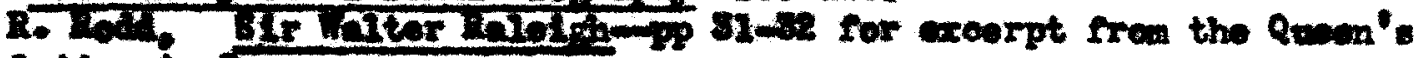
iotere to 


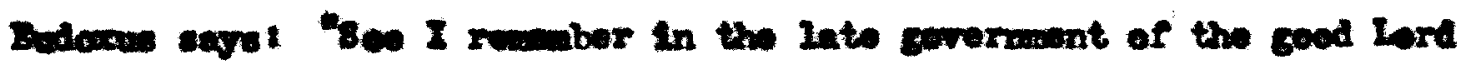

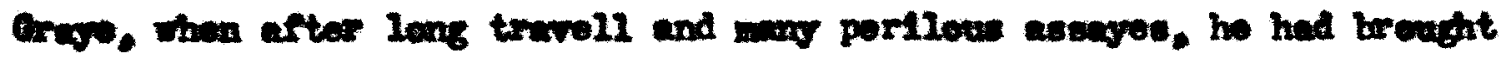
thinge alwowt to this pass that yo oponke of, and that won it mas wron wat roadye for reformation, and might have boon brought to what bor

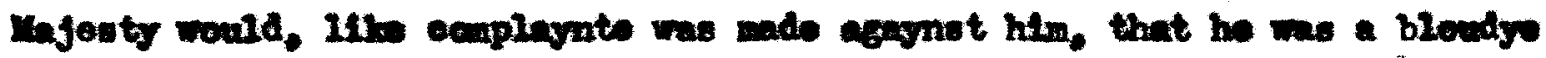
wan. and regerded not the lik of he mbjectes noe wore then degas, but

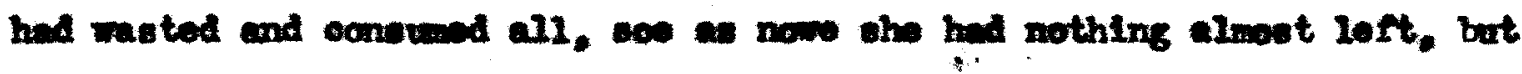

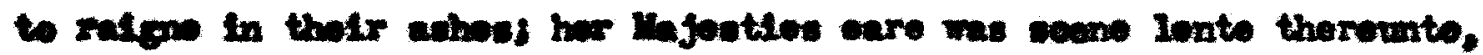

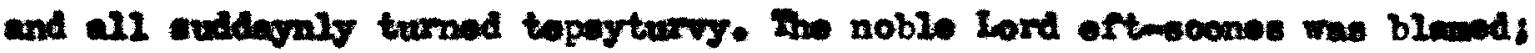
the motabed poople pittyod; and now oonselle plotted, in which it mas concluded that a general purion should be ent over to all that wowld wo-

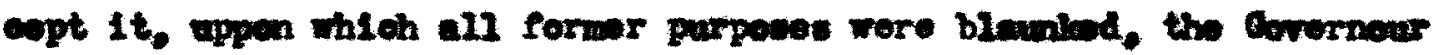
at a byy, and not oxily all that greate and lons oharge, which ah ba before bene at. quito loet and cancollot, but aleo that hop of goo whioh wa wen at the deore pett baok and eloane frustrated." Iho plea

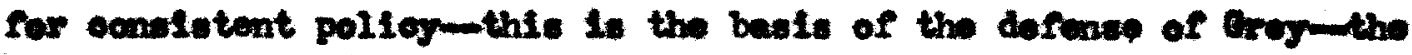

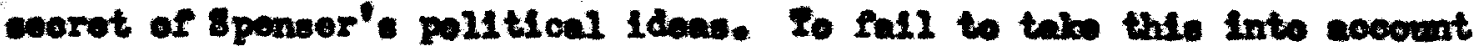
is to wise the rendwontal argwent in the poot's poilog. Inis is why

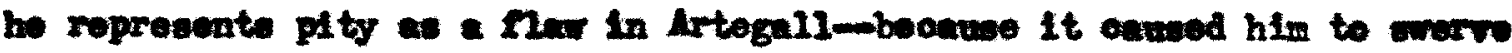
frem hil counse of justloo. This is why be approves ef Eroy's eleughter at sworrict. Sponsor was not, as many would oharge, a bracen-hoartod

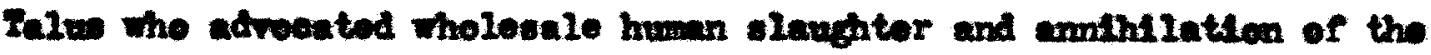

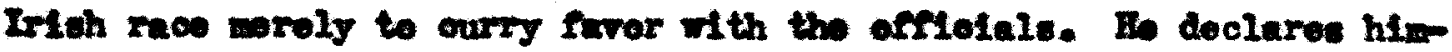

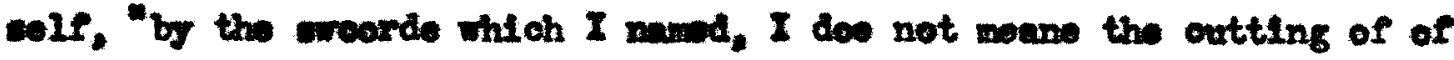
all that natien with the ewoorde which farre be it frow wo that I should 2 Ven. P 005 
wer think wos dopporately. or wish oo uncharitably, but by the oroorde

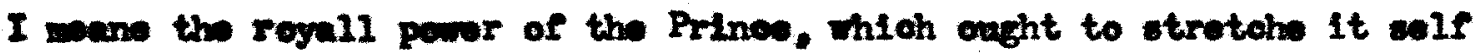
foorthe in the onlefoet strength to the rodreselng and outting of those orille, wioh I before blewa, and not of the pople fhioh are ovill. For orill people by good erdineunoes and gorernmont nay be made good;

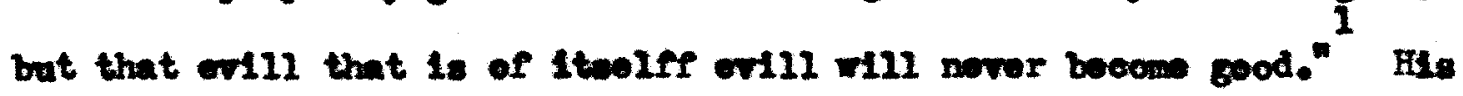
plen was to plea garrisons throughout the land to put dom the rebel-

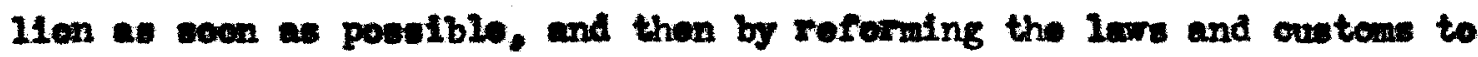
molo of Ireland a logal and profitable onbjeot for the Quon. If this

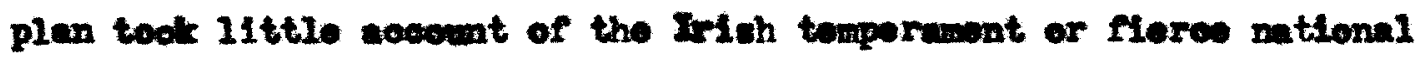
eplrit, It is not to be groatly mondered at, nor ohould wo condem the poet too harahly for 1t. In age of Elisabeth had no time to give to

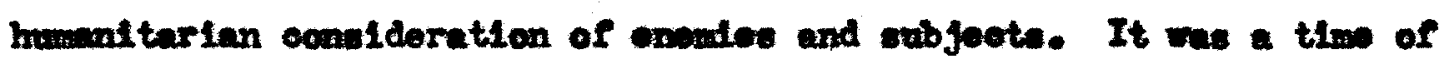

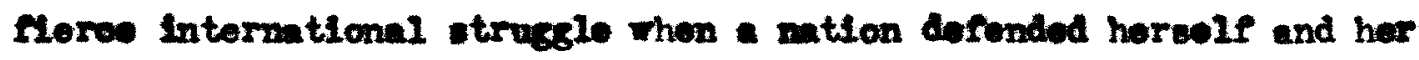
poseaselone at eny oost to inoure hor om ourdina. To be wure the Ith hated spmeer os "the biteredt and wost enthinidng of her onomes". but sposes wa the defender of Inglish euprowacy. It was en socoptod fuct in Bagland that the daminion of Ireland we noevesery for Bngland's enfety, if the was to provent Philip frow iming it for a bace for his om oporations egainet kleabeth. Dalny was dengerous and turwall mo rrealding the wole of Irelend. 8 ponser. towohod by the wretchod condition of the reloh, and realling the lwadinoy of the danger. ploade desporately for doflnito moaveres that would end the trovble and ettle the question Finally. Jaros is alrays orvel at best. but the eamiga which 8 poneer urged we oertalnly kinder in the long

1 V10., 800 
rw then the endloss oyole of coerelon, conoliliation, pardion and coerolen agaln whioh was woarling down both the IrIeh and the Shalleh. "It mest be forossene and ascured," ho writes, "that after once entring Into this oourse of reformation, there be afterwardes nee romoree of araing back for the olght of any ouch rustull objeotes wast thoro-

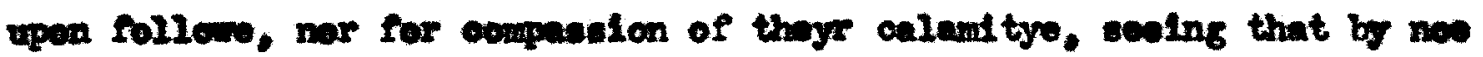
other moenses It Is posesble to swoure thom, and that these are not of

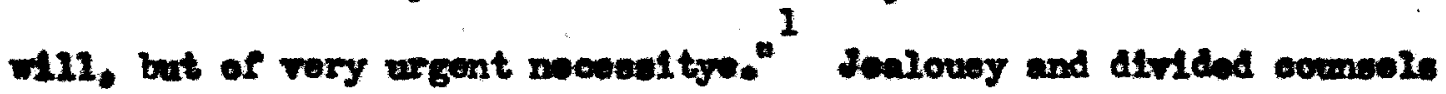
In Beglend, Burghoy" four of exponditure, tho frequont ohange of Boputionall these wore reoognized by those who knew the Irioh of tuation intimately a the root of the oontinned fallure in Ireland and atteat to Epenser's correot Alagmoete of the troublo. Lodorlok Brybett in a letter to Fal-

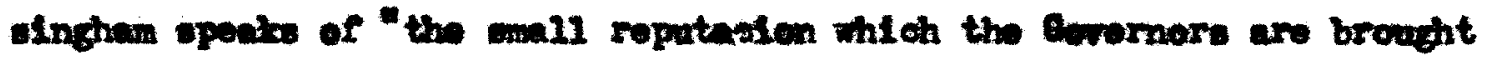
Into omons them (tho Irlah) for wast ef ocuntenanoe and oroditt from how, and the often expotation of ehange", declering that the Doputy could do nothing "onleses her Majentle and your honore there, doo better conbable him and alter the coures mioh now 1s held, ooumltting truet to him, that being oontimully here 1o better hable, and noreat eyomitnos, to discorn that is most expedient for the reformation of this miserable dicoriored countroy."

Eore wh have an explenation of spenser's intence fooling equinst change. Inle fuatiflos irtogali's words to the giant with the sooles:

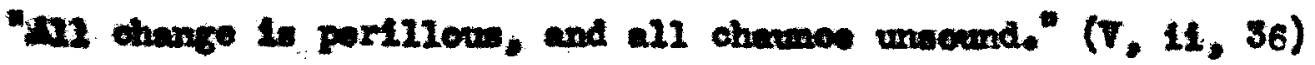

1 Vien, P 807

2 Plower and Crowe, Mfe and Correspondonoe of Lodorl ok Bryelote 
when be upholds the divine right of Ilnge and the ostablishod order of thinge. It was not that, a lagoule belioves, "Ipenwer did not

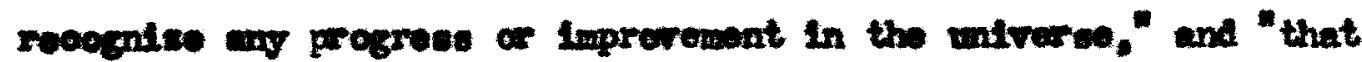
Hatabllity wight be a panos acertod for the good of wnikind was an

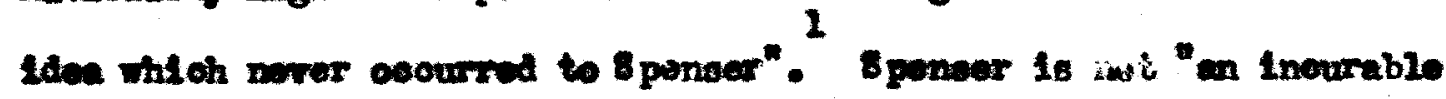
maloontent", but rather a will-informod man in pellthoul lifo wo sew the ord of inoonsintenoy in polloy and its disastrous roeults, and therefore sot them forth in his literary work. "8peneor diffored," save creonlew. "frow all other 11terary won of hil tim in that ho persistentiy olung to that oonooption of tho poot's rmotion that made him a vates, " "wear", a wen who should warn and advilse, dirootly throuth olowy allegorios, those the ruled Ingland,"

The froguent repotition of the theme of mutabillty only acrves to wake the moening wore ezparent. Lide from the examples in Book $\mathbf{V}$ and the Vine, the cantos of Mutabilltio bear on the seme oubject. The date of composition of these oantos is moertain, but the tono is that of a later work than Book $\mathbf{Y}$ and the roferenoos to Colln

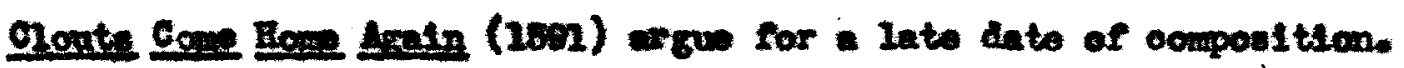

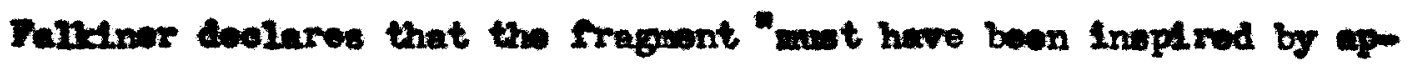

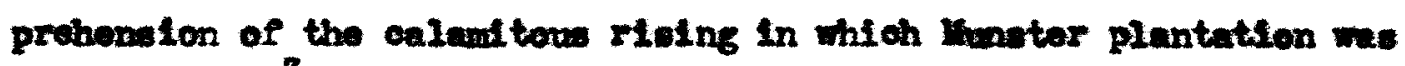

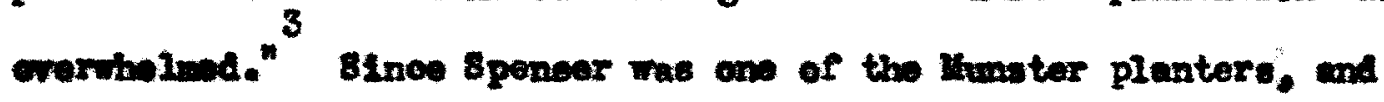

1

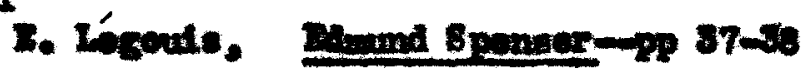

2

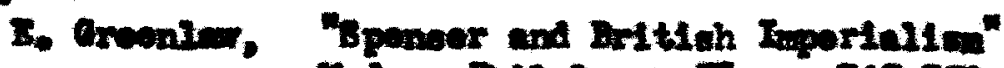

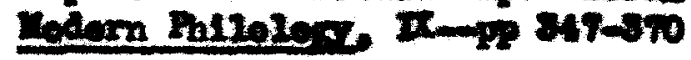

3 A. C. Ralkinor, Adinburth Revier-1006 
wem the oonatant menace of attack from the rebels ineliling in the noarby forests, the last lines of oanto of secin to support this view

Bince mich, those Hoods, and all that goodiy Cheso

Doth to this day rith Folves and nilevos abound:

Fintoh toowtoo true that lands inmarilers elnoe heve found."

If we accept the theory gonerally hold that the cantoe of

Uutabllity rere intonded as part of the Baeris Qgeeng then we have Constanoy celebrated as ow of the twelve moral virtues and the glanteses Hutability the opposing vice. Inis is oortalniy Sponser" oonooption. Iutability is constdorod in the sam Iight here es in Book $V_{\text {. }}$ a powor haninal to sorerelgnty and to Justice.
"Fo the the Iowee of Iature onely brake.
Dut olw of Iustios, and of Poliotet
And mrong of right; and bad of good ald mako.
And death for lifo exchanged foollshlles
Sino whioh, all IIving wights have learnod to die
and all this world is waxen dally warse." $\left(\frac{1}{2}, 6\right)$

The glanteseo in her pride attaclas Oynthin (Misabeth).

1

Cf. E. X. Abright, "Bpenser" Beasons for Rajecting the Lutaililty

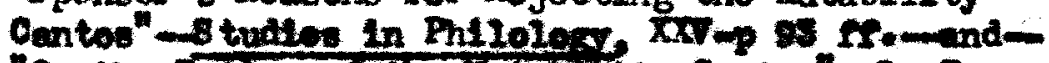
"On the Deting of the lutatility centoe" -5 . F. $\operatorname{xan}_{\rightarrow} 482 \mathrm{fr}$.

Mes Mbright belloves these cantos were writton in Finglend about 15790

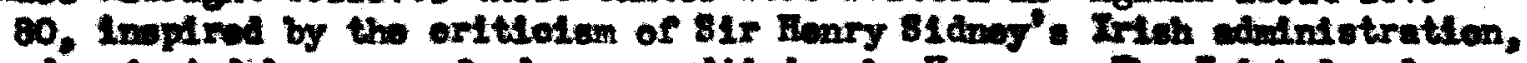

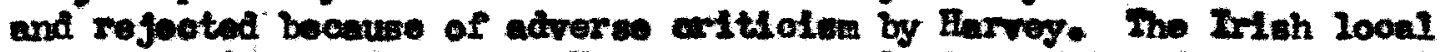

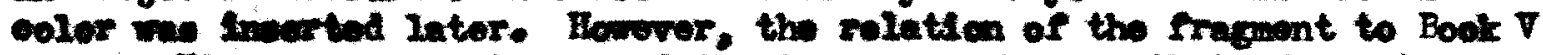

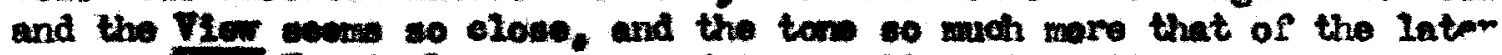

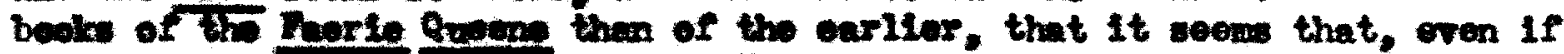

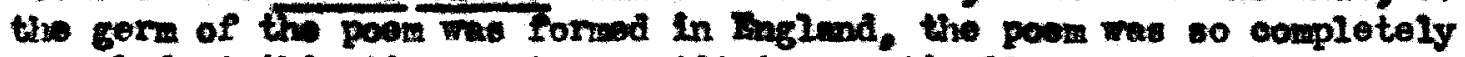
roworkd at this tim as to ocnstitute practiouliy a now rork.

\section{2}

Cf. Letter to Ralelgh-s penser says he has wed Raleigh's conoelt of Gathia to shador Mixabeth-Gythia is Bisaboth in C. C. C. H. A. 
" boldy preacing-a, raught forth hor hand

To pluck hor down poxfores from off hor ohalres"

eleluding the right to rulo in hor atead, and coelering hor ouperierity wer the wry gods. Cynthis stopped in her oouree and the rorld is throw into dariwose. So wutablity attaciding Blisaboth on hor throno

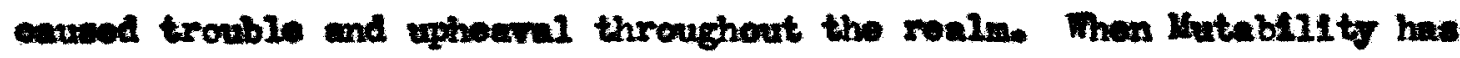

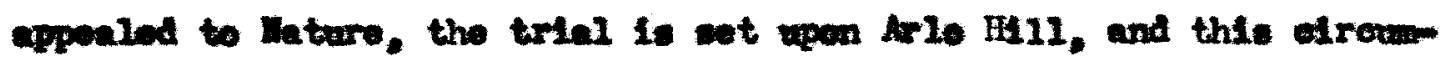
tanos seme to IInk the problem definitely with Iroland, for there. In truth the polloy was on teinl and with disuotrow results. Cynthia Is desoribod by the arrogant ritaroens

- har faos and cewntoximo crery doy

The obanged soe, and wands form partake

Eow horn'd, wos round, wor bright now browe and grag:

Bo that as changend as the Hoone won woo to say."

$$
\text { (rit. Bo) }
$$

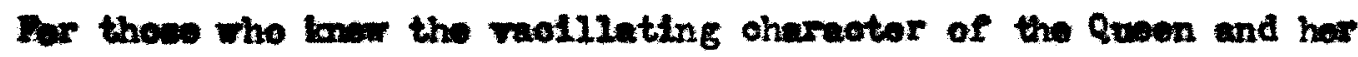
gowermont there wa 11 ttle ned of aplenation of this allegery. Hature's Jutguent is spenser's om-in farer of the ootablished order of things. Though the admts ohang in all things jot she doelarea

- oner tham Change doth not rule and raignes

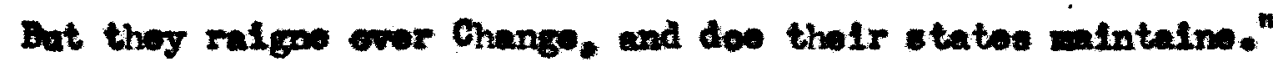
80 the gode are confirmod In thoir seats. Canto ril, howver, begins rith a ecmpleint from the poat.

"Thma I bothinke on that epeech wyler Or Matability. and will it way:

Neanases, that theagh ohe all wororthy were 
or Hewren's Ralos get very eooth to sexy,

In all thinge else she beares the greatest on

Wich wakes wo loath this state of IIfo so tiokle

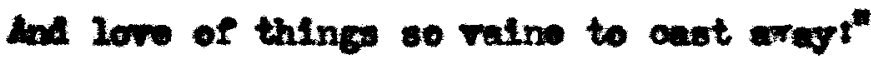

1

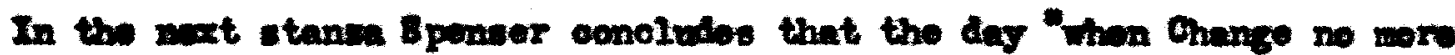
ahall be" Is to com only with a golden age, and bo bage bed for a - Licht of "that Babrots".

41 this weine of a 2ate poriod in the poet's IIfe thon he folt he had deno all in his powor to show to the oourt the rolly of

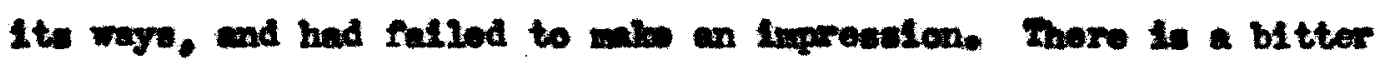

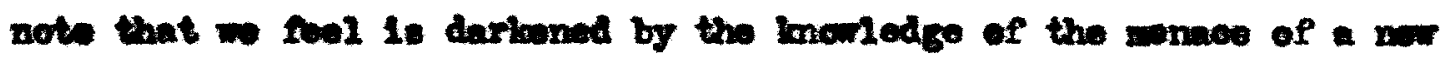
robelllen wheh might bero been aroided.

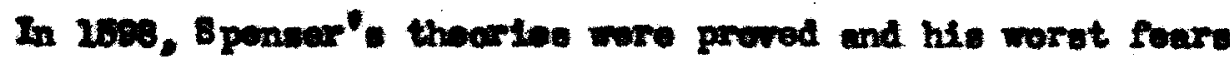

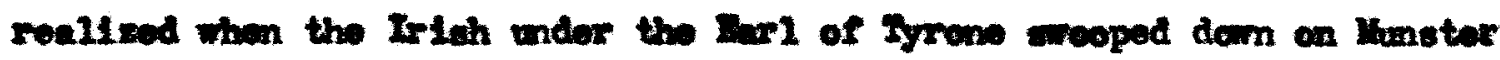
and pludered the lands of the Bnglith planters. Riloolman mas ruivid and the poet fled to Cork. The letter to the Qween mitten in 1500,

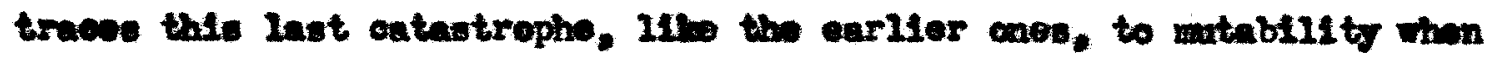

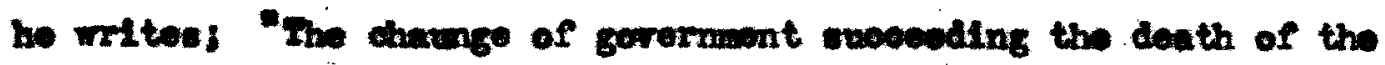

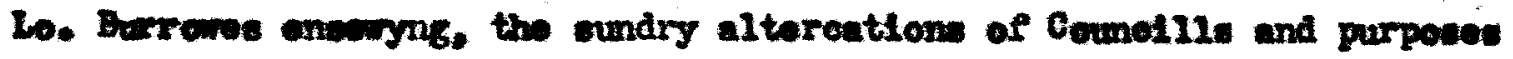
folluring, together with the division and partaiding of those theseselves of you Comolll hore, have sinee brought thinge to that dangerow con-

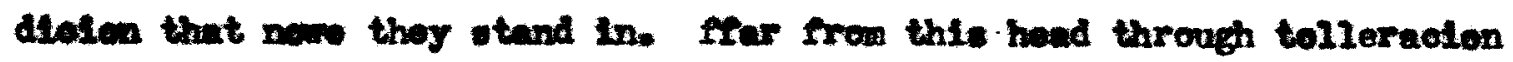
and too moch tomporising the orill is spred into all partios of tho loalw and crome in to 00 universell a ocntagion thint nothing but a

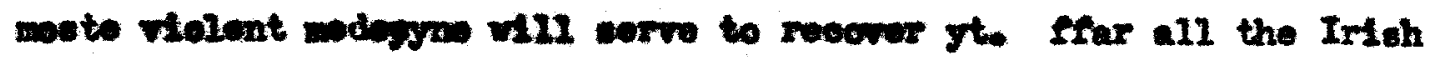
of all partios are oenfodarated and huve genoralls agroed to thake of 


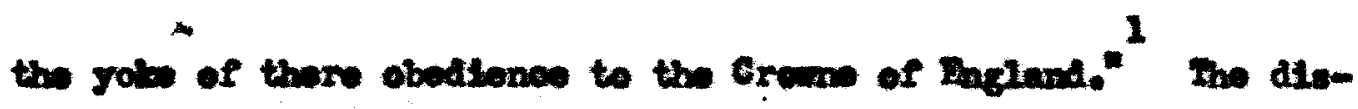
appointenont whioh is ahow in this tract boars orldenes to the folth spenser had put in his plen and the grief bo folt at its at being booded in tise. The daring of the etatement proves ito olnoersty.

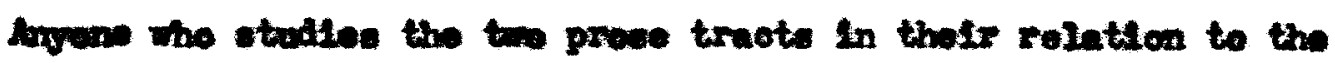

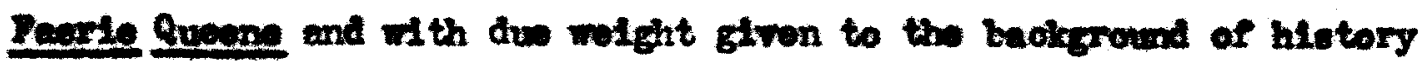

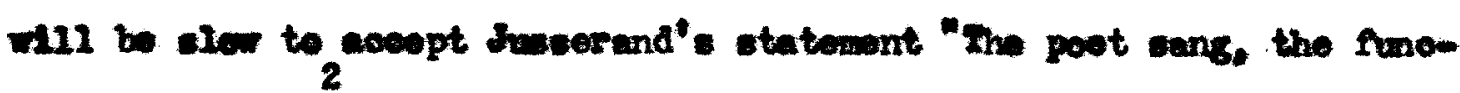
thonary revise." On tho other hand, the poet and the nunotionary ere cose, and the utterenoes of the forwer cunnet be fully understood mlewe

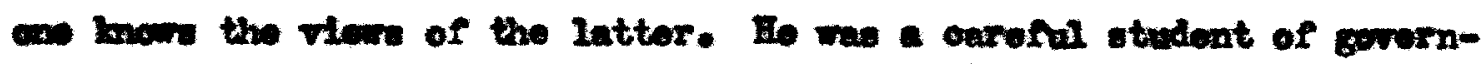
wht and he conolvations are sinoere and coneletent. HIs experienose In Iroland and his intimate connoction with the Irleh goverment, if thay dif not sotwiny form his political thoorlos, at least oryotallisod thom and gave them oonvietion, so that he became in Ireland "the lawrosto of the now Ingland, defending that national polloy which, however orvel and narrom in som of Its applicatione was to enablo hor to thrart the foes that throatened bor dotraotion."

1 Brtaf Dte of Ireland-in Irent's Edition of Eorke $\rightarrow 846$

2

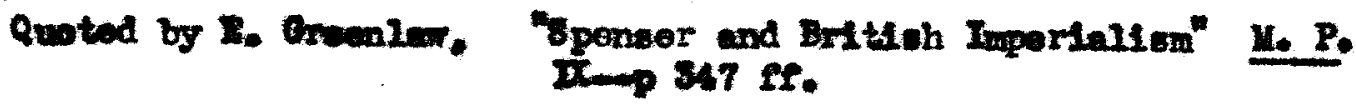

3

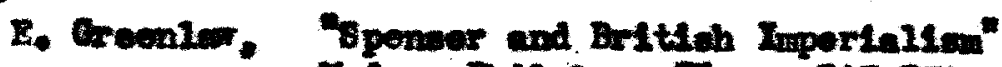

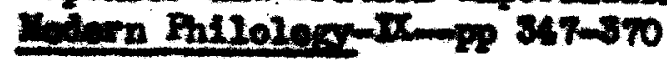


CRAPER II:

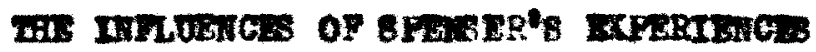

I

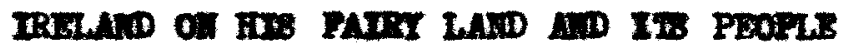


GXPISR III

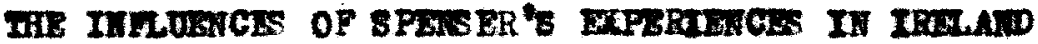

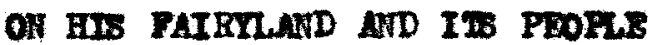

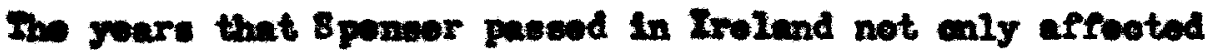

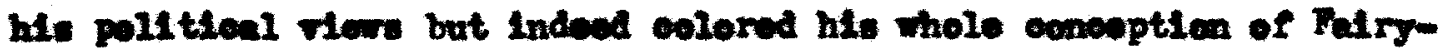

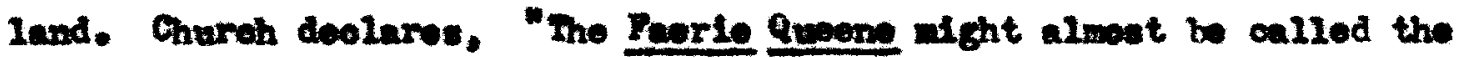

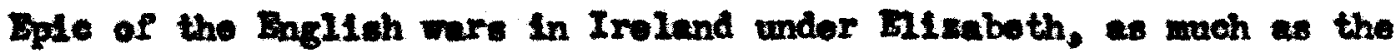

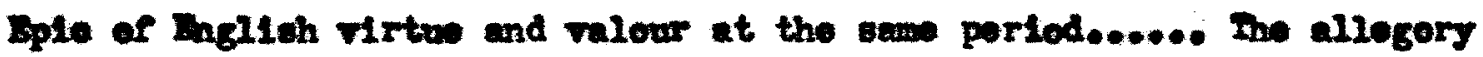
bodles forth the trials wioh bovet the IIf of men in all conditions and at al tiwes. But 8 poneer oould nower hav ween in Inglend ouch a strens and perfoet imge of the allegory Itself...... It oamot be doubted that his iffe in Irviand added to the foros and rividnese with wieh sponser wrote. In Ireland, he had before his oyoe eantimally the aroary weld wich the pot of inight orrantry inginos. There won in good truth afgt trwol lons through wildomoses and 'grout reods'

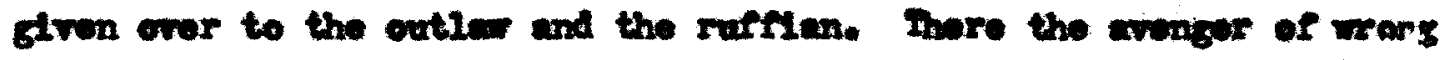
nod seldom want for partlow adrontare and the ocostion for guiling the epprosedr. There the armod and urelonting hand of right was but teo truly the ouly oubstitute for 1w. Thore wight bo foud in nost

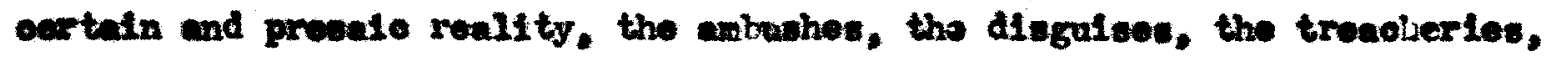
the decolts, the tomptation, wan the supposed ritoh orafte and onchantroute, againot with the fairy chapiens of the rirtios have to be a thoir guard. In Irolend, Daglithion ow, or at any rate thoaght they w. a mivereal battle golng on botwen orror and religion, botwen 


\section{5.}

juetion and the most incolent selflshness. They found there overy type of what mas orwol, brutal, loathecas. They our overywhere mon whew bulnese it mo to betray and destroy, wowen whose business it wa to tempt and onmare and corrupt. Thoy thought thoy sai too, in theee the waged the Quen's wars, all forme of many and deroted gallantry, of noble generoulty, of gontle strength, of knightly oweetnese and courtosy. The reallties of Irish social and political 11 fo gav a roil oubject, gure body and form to the allogory."

Same of the most porrerful and momorable paseages in the Feerle Quen ow tholr Inapiration to Irleh happonings wioh the poet wtmesed. The froquency of the ocourrenes of evoh refleotlons, and the fact that they appear often in parts of the allegory having nothing to do with Iroland, showe how the atwouphere of the land bocem an in tegal part of 8ponser's pootical beckfround. The passages to be oonstered in this section deal with actual experionces of 5 penser in Ireland.

It Io reasonable to suppose that spenser, es secretary to Eroy, would have accompanied the Deputy on many of his expeditions againat the Irlah. From his om statement in the Vler of Ireland, wo lono that ho Wan at the capture of smerriok. Horeover, he acqualntance if th 31 Fenry 8Lanoy, Sir Nalter Raloigh, and other offloials and oaptains in Dablin, would aceount for an interest in ard a lnowedgo of rarlow oam palgne wich tock place bofore his errival in Ireland, or on which ho did not cecanpany the army. Prom the Irtsh mars, sponear got his backgrownd for the doscriptions of behealings and battles. wany of which

1

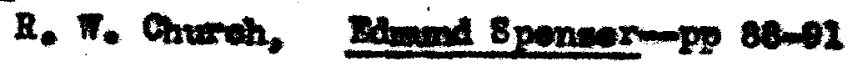


secen painted realistionlly from opeolfte inoidents.

Crog"s adminietration ras one of continual mar, and bloedshed

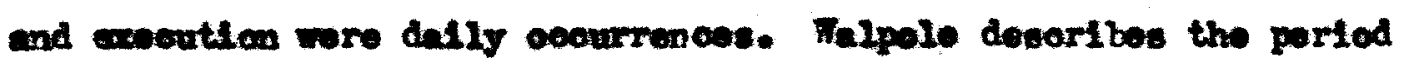

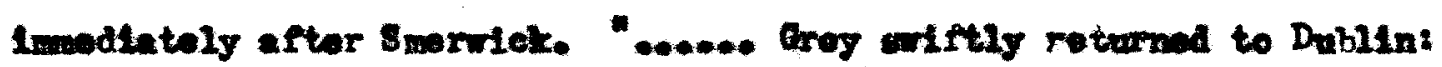
thare he arrested KLIdare and Lerd Dolvin on supploten, and Mung them Into prisons ho turnod arvagely on the Nloklow insurgents, and, tanght by his exporitenee at Glonmelure, organieod a number of anall bands to

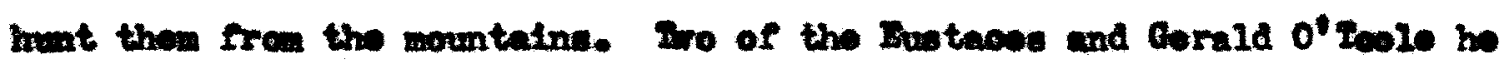
oaught and behouded; but Baltinglas enoaped to the Continont. A reign of torrer then began at Dublin. A conspl raoy to wolse the castle and 14 berato the Imprisoned peers was discorered, and martial 1 m was proclatiod. The maller won were hanged in betohes, and ninoteen of the beat bleod of the Pull were brought to trial for treason. short work was made by pliant furies, and the whole of them woro comrloted and henged" cenofen. "Orwonde onught and hanged tady Pitugerald of Imokelly and reports in his despatohes the exeention of 234 persons, and that the pardoned ohlefy wore bringtng in the hoads of other robels by the sackpl."

Though wo bellewed them nowesenry, sweh owente as those struek horror to 8 poneor's heart, and when wo know that ho wust have witnosed

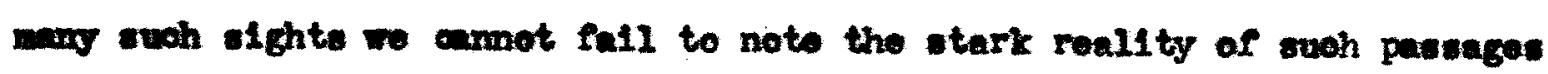
as the deseription of the abode of Despair.

-And all about old stooks and stube of trewe. mereen nor frutt, nor leafo was over socene, DLd hang upen the raged rooky breves: On whioh had wang wretchos hanged beeme,

1 c. 6. Finole, Short Hietory of the Kinden of Ireland $\rightarrow$ P 101 


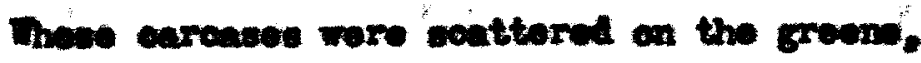

An thrown about the ollefs."

$$
(1,2 x, 34)
$$

Boside the old man

$$
\text { "Mere lay upon the grew }
$$

A drente coree, whose llpo way did pos

All mallon'd In his om yot lukomarw blowd,

That from his wound yot wollod troek slast

In wioh a rustio inis fast fixt otood.

Ind ade on open pasage for the gushing flood."

$$
\text { (I. } 1 x, 86)
$$

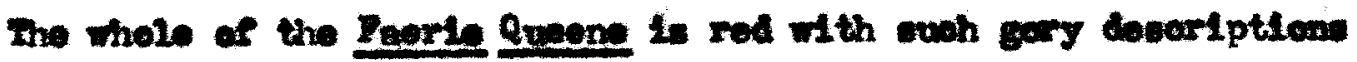

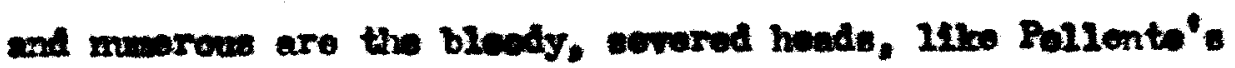

$$
\text { "That trubling on the atrand }
$$

It bit the earth for very foll deapight

ha craohed with his toeth."

$$
\text { (7. 11, 18) }
$$

And oven wown"s heads are not Irviolete, for Brror is dewapttated $(1,1,24)$ and Radigund, theugh spared by Artogall, is boboaded by Britomart. (V, Ni, s4)

Ilany of 8penser". "Wloked wights" take on the lineawonts and oharactoristlos of the Irteh rebels them 8 ponser ant, and the battlos agalnst them often bear a marked rosemblenes to cortain IngIlsh expatgos in Ireland.

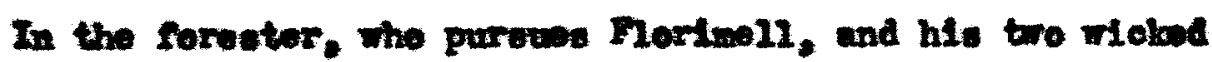

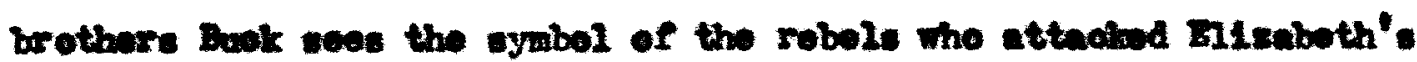

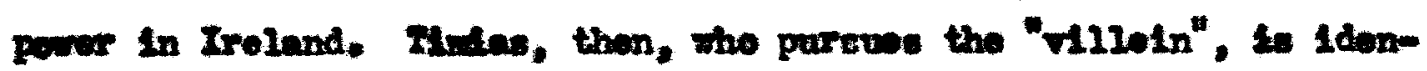


thiod wth 8fr Waltor Raleigh tho eorved in the Irteh ware. Tho

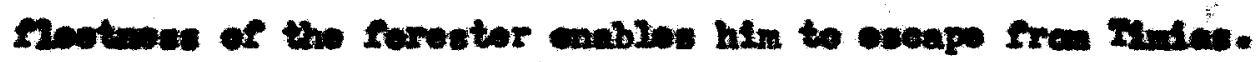

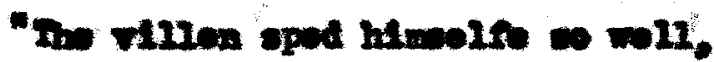

Whother through the extetnouse of hle epoode boast Or moniedze of thowe roods, whore be chld mell,

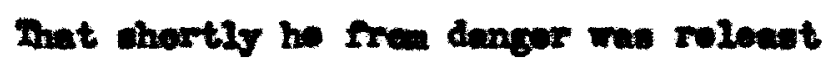

Ind out of elght escoped at the loast"

$$
\text { (III, } \mathrm{r}, \text { 14) }
$$

The forester then wot about gotting roverge on the aquire, and "Wth bittor worls be etind to bloody iro" hls brothere who ogres to ald bine Arwod, thoy proevod into the foront and etation

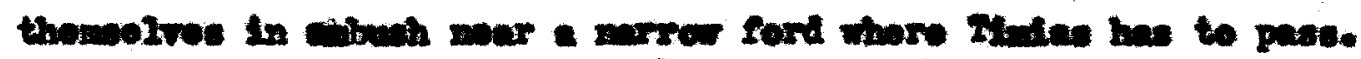

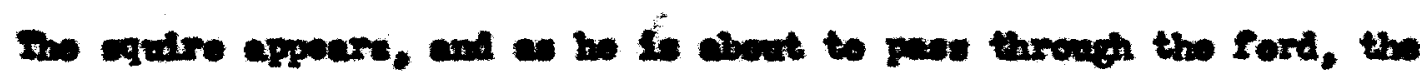
roroaters attask blus

- That itrollo the hardy 8quire ald sore diepleace

But wore that Min ho covild not com to valto;

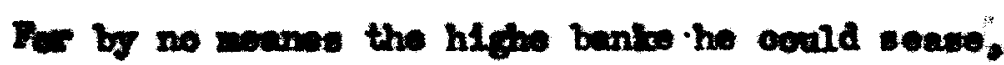

But Inboured loms in that doope ford with valne diseweo."

$$
\text { (III, } \nabla, \text { 19) }
$$

Fren tholr ventage polnt abow hly, the foresters mall tholr darte

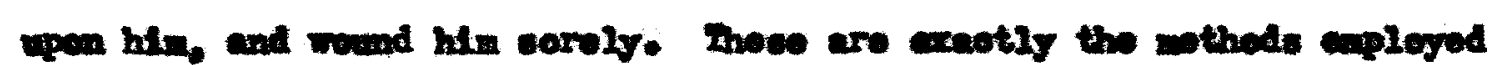

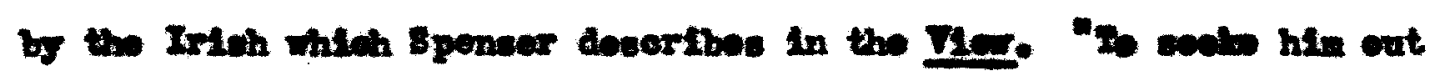

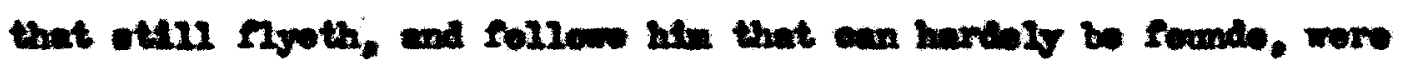

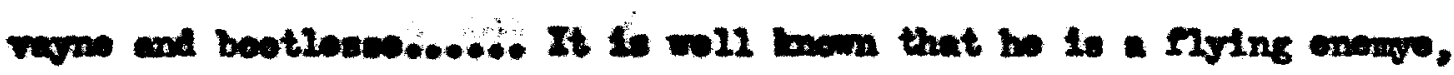
hiding himele in woods and bogen, frem wowee he will not drawe

1

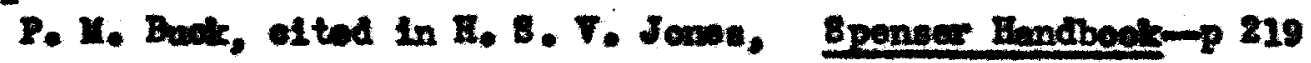




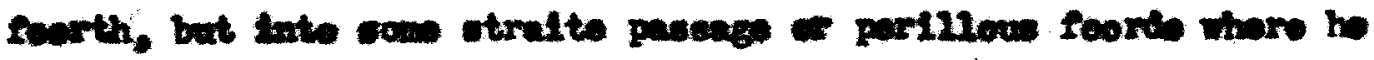

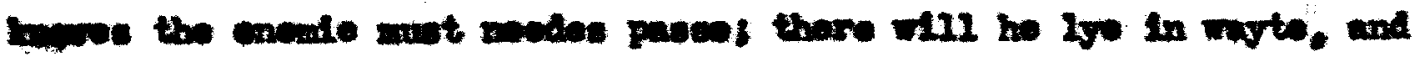

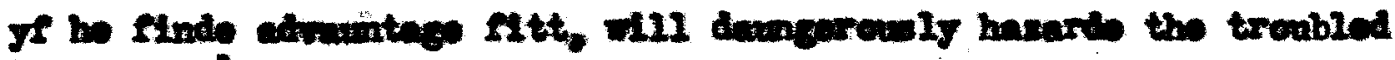
condater $*^{2}$

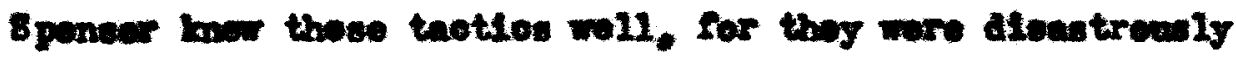

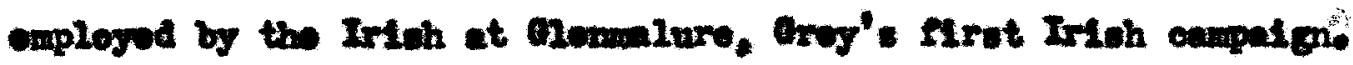

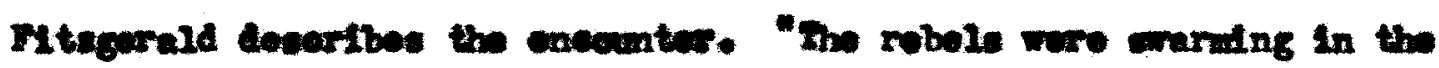

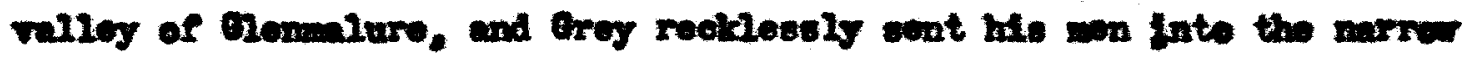
sore. belleving he was streng envugh to hent thow oat. Whon tho

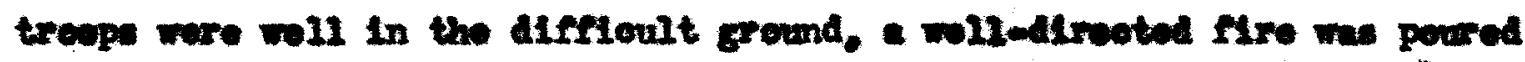
in upen thos frem the eafe osror of rooks and brulinend the coldter. atvanoed through ground that boowe more and noin diffioult with overy

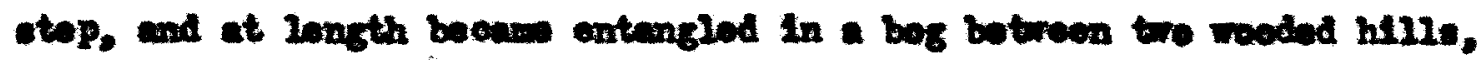

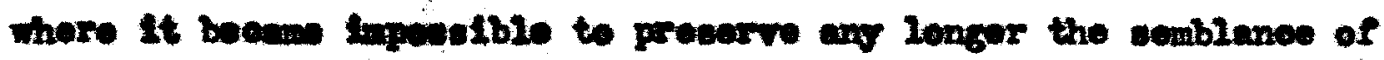

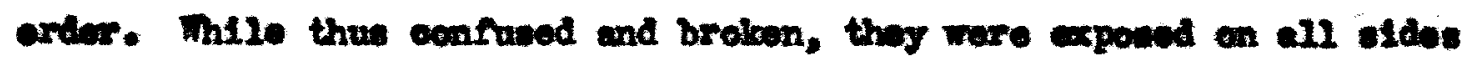

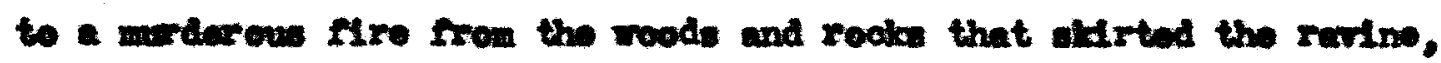

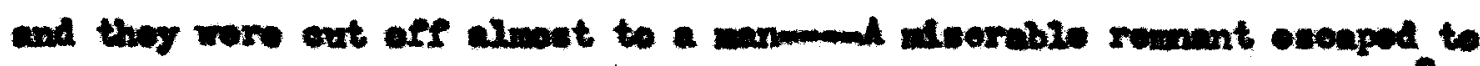

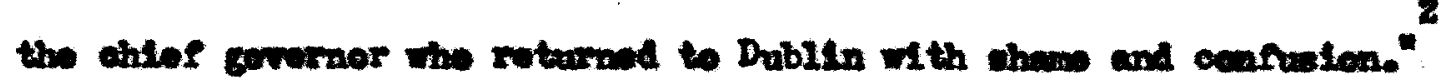
Enoy watchod the battle frow the lovel ground at the wouth of the glon. and sponser wa probubly with hin. Mny of tho dotalle. doubtlose.

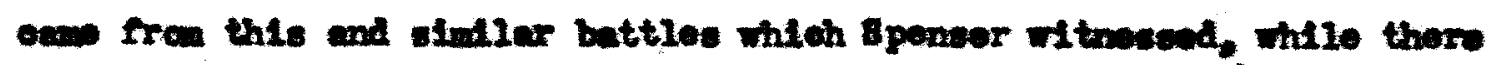

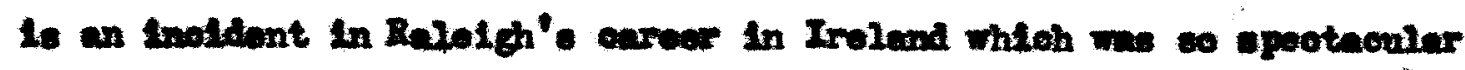

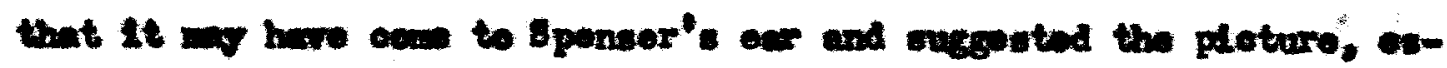

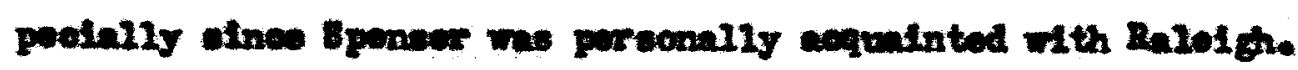

2 Ven. 801

2 2. I. Itagerald, Irelend and bar Fueple-rol, IV 
Ralolgh had been eont against on Irish robel, David, Lord filyy, but the apodition was thrarted by the lord's burning his own captle end rasting the surrounding land, and therafore baleigh and his wan etartad to roturn to Dablin. Botwen Lougl and Cork was a ford in the Balmacrarra. Hore there lay in abosh, wathing for his

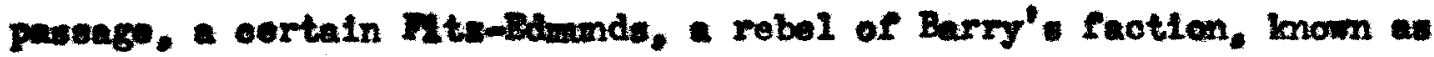

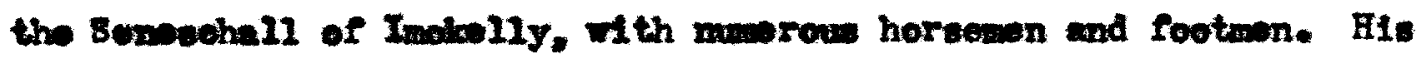
Litle enoort of elx wen wore lagging behind, and Baleigh reachod the

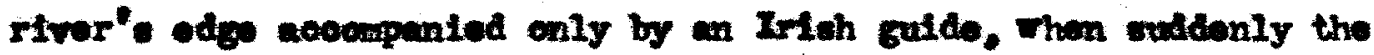
wholo ocupany of Fitrmatumds oprong from their hiding and held the ford. He out his way through and had oreseed in s afoty to the othor

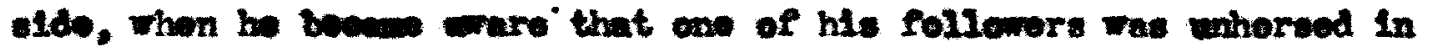
the wdale of the atroan and orying to hil for holp. Daning back into the rivor he brought the men enfe to land, and then with his pistol oockod stood flrm on the opposite bank; waiting for the reat of his party to wose up. The seresohal. eoelng other treopere advenolng in his roar. wad off in hevte, al though his foro moibered brenty to $\sin ^{1}$

The fact that the eloge of smorvick if portrayed in the battis with Grantorto he boen trested already. In addition, it is werty of note, that though the giant represents a foreign imvader. ho is arraved 1ike en Irith chleftatn.

MI arwa in a oote of jron plate. of great dofenes to ward the dendly feare And en his hout a steolo oap be did woare

1 R. Bodd. 81rnoter Raleth-pp $32-33$ 
of colour ruatte brome, bet sure and strons:

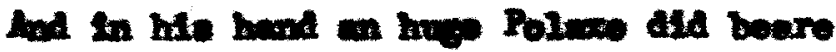

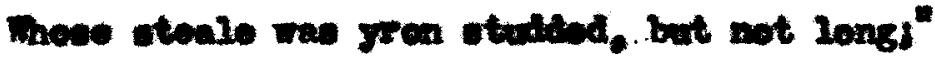

$$
\text { (v. } x 11,14)
$$

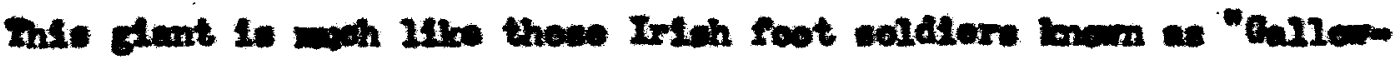

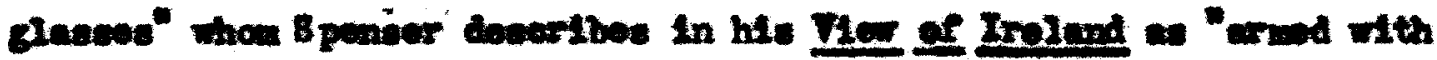

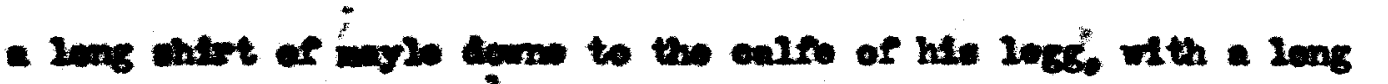

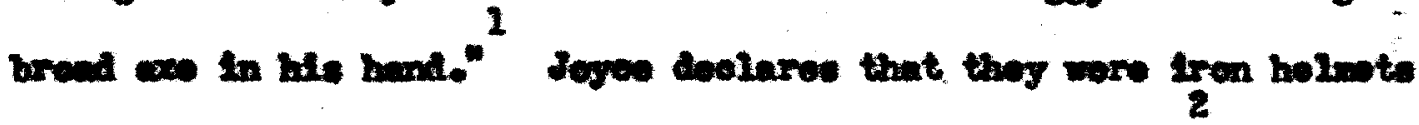

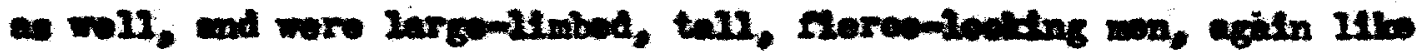
Grantorts:

"Of etatare huge and hideove be was 14b to a Aant for his wenstrous hight

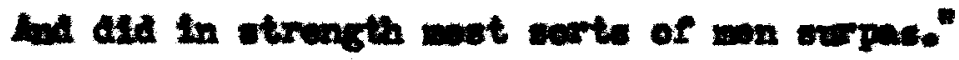

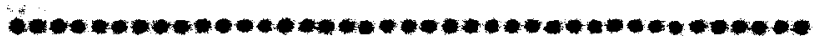

IfIs fwo was ugly, and his ocuntonernes otorne That could hase frowa one ath the vory etighto"

$$
\text { (v. } 211,25)
$$

Halongln awe woh of his charmoter and appearnos to the

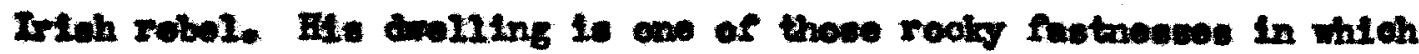
the Irtin were drtwen to take refuge. Jenos polnte out an intereating

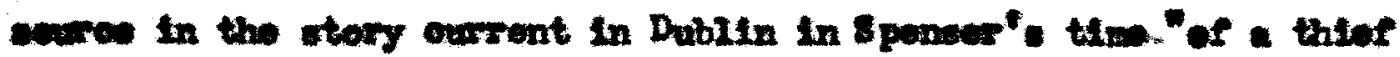

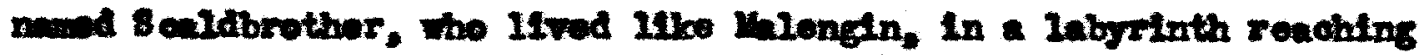

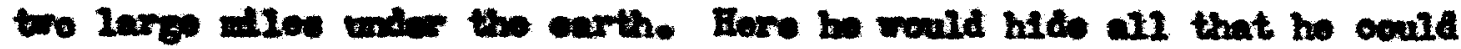

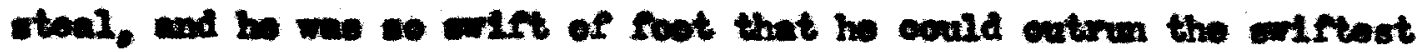

1 Vies, 700

2

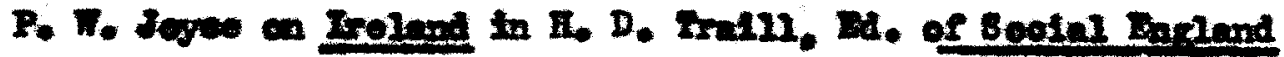


and Intiect young won."

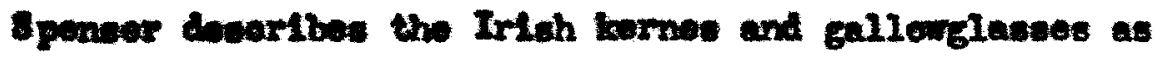
hasing the mont loathowe and barbarov onditions of emy poople (I

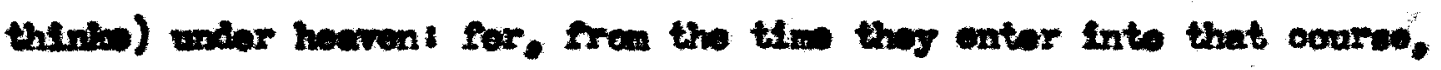

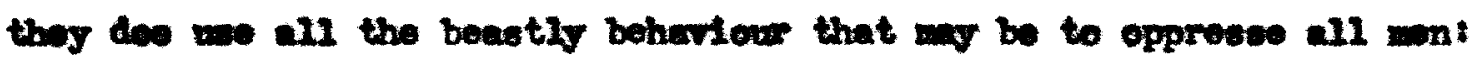

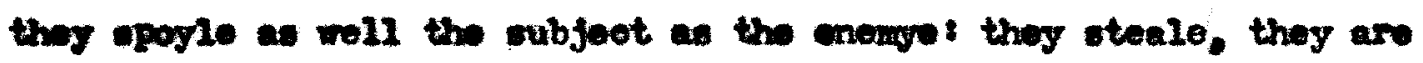
croll wa blowdy. Sull of rowenge and delighting in deediy exocution,

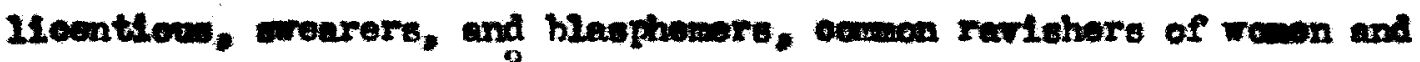

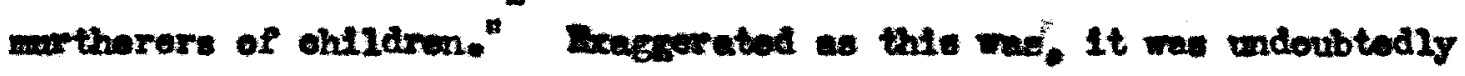
the ovmon Inglieh attitide tarexd the Irleh kerne.

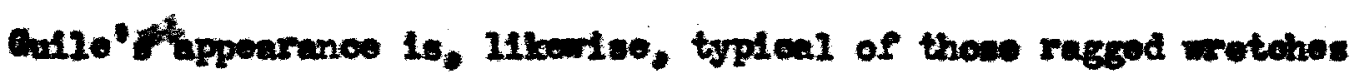

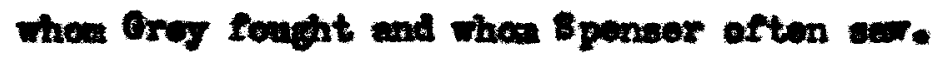

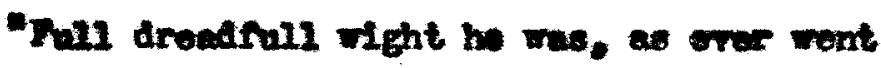

Tpen the oarth. Ith hollow eyoe doep pent.

And long ourld looks, that dom his showdere thagged

Lad an his back an moouth wertinent

Hade of straunge etafre, but all to rome and raced

And wderneath his bropah was all to torne and

$$
\text { jaged." }(N, 1 x, 10)
$$

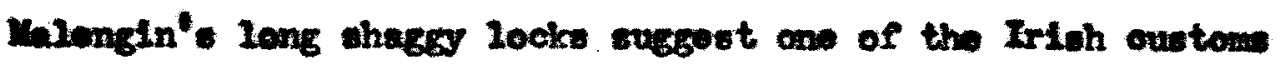

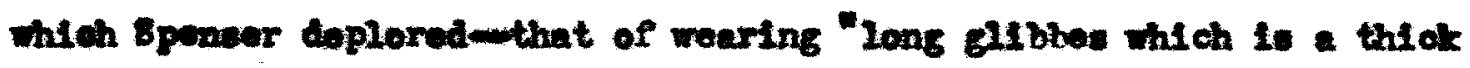

1 H. B. T. Jenos, Enaboik-p 28

2 Ven. 900 
ourled buch of hoare, hanging dome ovor thegr oyos, and monstrous-

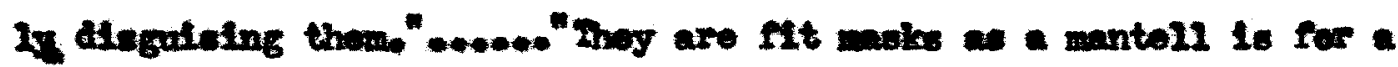
thief. For wensedver be hath rum himself into that perill of 10me that he will not be knowen, he elthor outtoth his glibbe qudte, by which ho becenoth nothing like hlmolf. of pulloth it so 2010

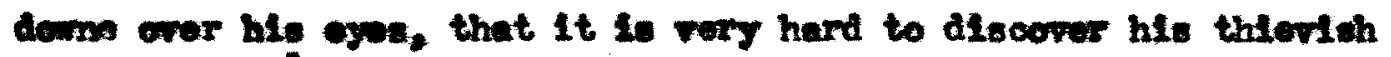
countennence."

Thie wan does not wear the oent of mell 21ke Orantorto's, for It would be a hewry oncumbrnoe to him in his hasty fight. So, 8ponace tolle w, wny of the Irish proferred to go "to battell without armos on thegr bodyes or boades, bet trusting onely to the thiob-

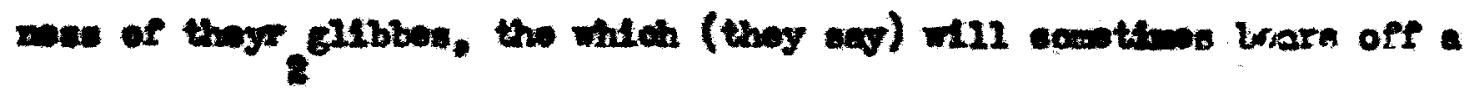

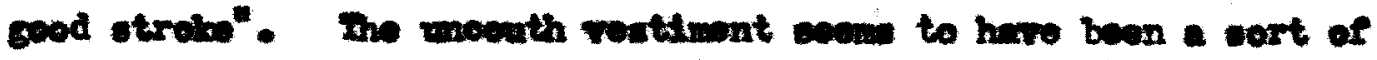
mantlo conwonly worn by the Iriah, whioh sponser show in detall to be " Altt howe fer on outzeme, a weote bed for a rebel, and an apt oloaks for a thief" -merefore very appropriate for erentorto.

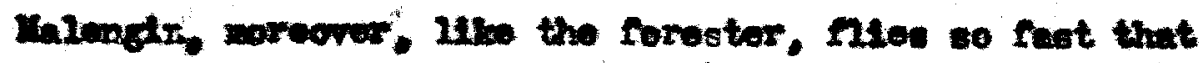

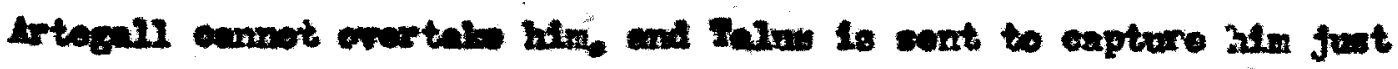

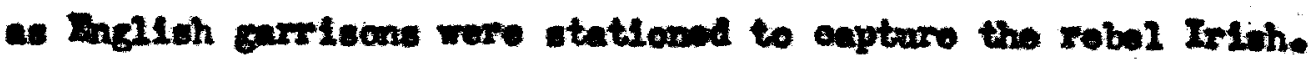
Wise Gray has pointed out an interesting parallel in the fate of llalongeln to the doath of the Rorl of Dowwend whe whe traced

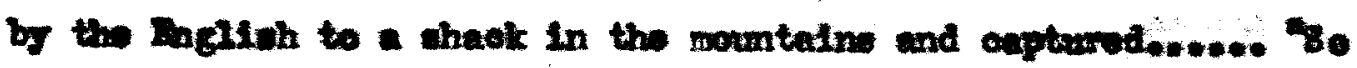

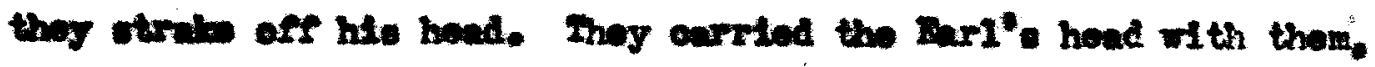

1 IDP 700,702

2 I0

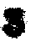
IIes 700 
but laft hls body bohind, and whether the seme wes deverosed of rolve

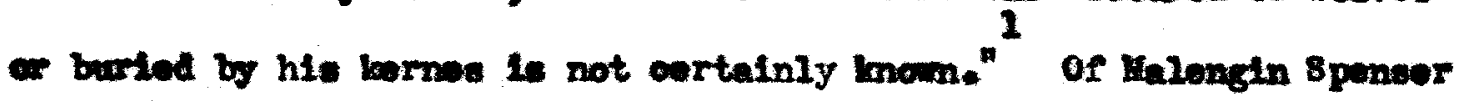
seven-

$$
\begin{aligned}
& \text { "More they hin left a oarrion outoeat } \\
& \text { For beasts and foulos to foed upen for their }
\end{aligned}
$$

$$
\text { repast." }(T, 12,19)
$$

The alaughter of Pollento, acoording to both Oray and Henloy finds almost waot countorpart in the acoount of the douth of John of Bosmond, the Barl's brother, in 15sl. Hoolow doclarva: "84r John's heed wes sent to Dublin, but his body was hangod up by the heels upow a glbbet and set upon the North Cate at Cork." Artegall baheaded Pollonts and

"Hila coepo was oarried dowe leleng the leo, Whose wators with his flithy bloud it staynod:

But hio blasphomow hoad, that all might wee Ho pitoht upon a polo on high ordaynod; Where smy poars it aftormards romagned, To be a marrour to all wighty mon, In those right hands grent power is conteynod, That now of then the noble owerren Bat almileo doe thoir powse within fust ocmpasee pen."

$$
\text { (1. 11, 29) }
$$

1

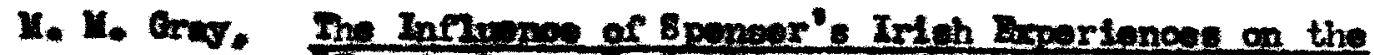

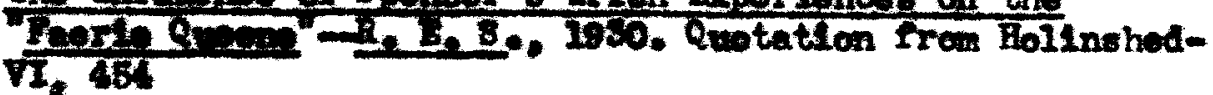

\section{2} P. Bonley, op. olt. pp 130-141

3 B. Holinahod, Chronteles VI, p 416 


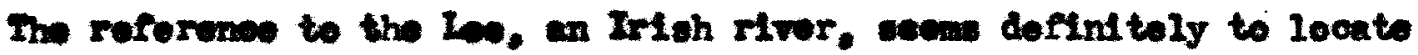
the indident. On aceornt queted by Oray states that "the bedy was hung over the river los en the Dorth Gate of Cork," and another guoted

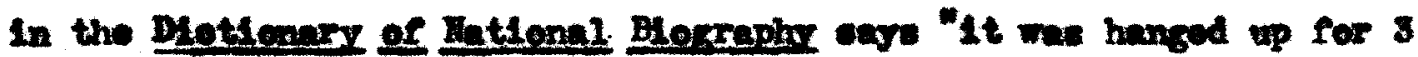
e Hoare togothor as a spotade for all boholdore to lock on, unt1l at length a great storm and wind blew It off. but the hoad mas cont to Dublis and then was fastenod to a pole and oot over the olty vall." sinoe Spenser was in Dublin at that tiw he world certainly have coen the hoad weong the othere aptlad an the oatle gate. Honley asserts that It ang have wen oove into the poet's hands since it was sont as a now Tear'. gift to Goy.

Hamer. atteapt to bribe har eaptors, and the fate infileted

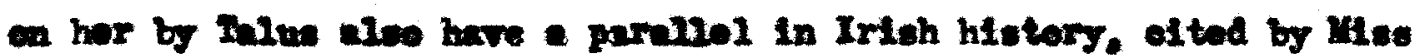

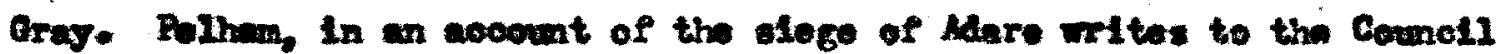

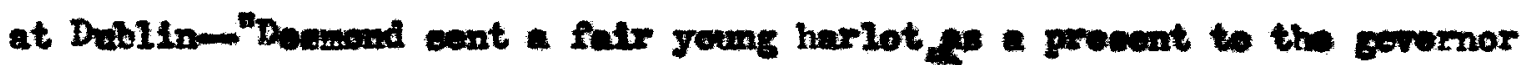
by whowe wand he hoped to got the howas, but the oonstable learning

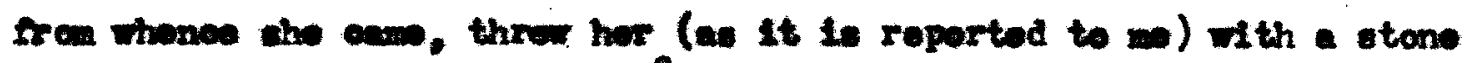
abeut hor nock into the river." ${ }^{2}$ sinos Bponser was soorotary to Groy. and was "treated as seoretery to the Lord Dopaty and the Council." ench a report wa woll be eupposed to have peseed through his hands at cost the. Munera's hands and foet wore chopped off and malled up, and then Mive throw hor ever the wall into the river. As Eray points out,

1 - Tentoy. op. olt.p 139

2

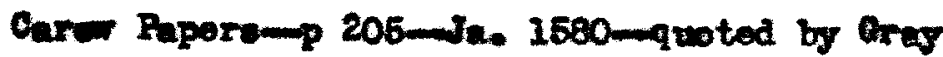
3 F. I. Carponter. Reforence Gide to spenser-p 16 
the inighte who wecute woh punishwents are not "vory parfit gent12 lnighte" but rether Englieh orficials driven to omplog doeporate wiothode. Frequently those with whom the Fairy lonichte mut do battle wo not single foos 11 re Pollente and Halengla, but the whole "reovel reat". In Book $\nabla, 7,29-30,7,11,51-54$, we find the orowds which

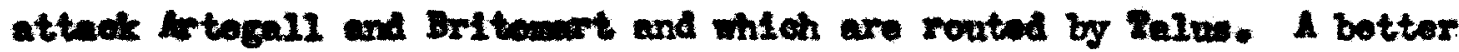
plotare to to be found (II, ixact) In the attack of the Puselion on the Howes of Tomparanes. The rabble rout is 14 be many 8 penser must have seen during the exmpigns agalnat the robels.

1 thousend villolne round about thom anared

Out of the rooke and onves adtoyntins nye",

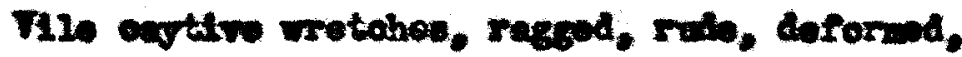

41 threatoning douth, all in atraungo veninor arma,

Somo with rumeldy olube, come with long operes,

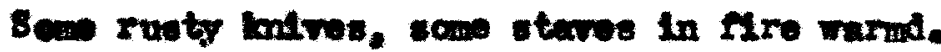

8 torw wes their looke, Ilke wild anased steares

starline with hollow eyes, and stiffe upetanding boares."

$$
\text { (Ix, 2x, 13) }
$$

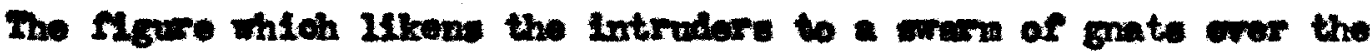
"fonnos of Mlan" soome an added indication that the poet had in wind an oront mioh took place in Irolend.

Tho"villoin" are ropaleod, but roturn again and agaln. Thoir

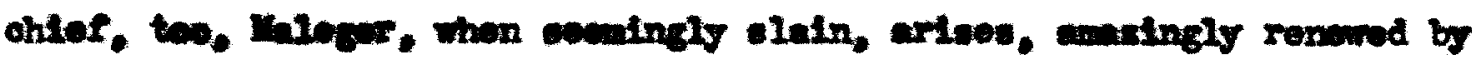
contaot with Earth, and rosumes the fight. 80 the Irieh had a romarbablo

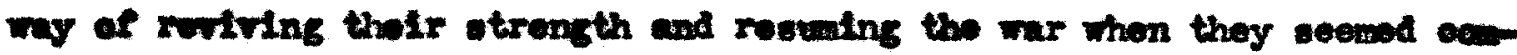
plotely rabdud. The valor and endurance of the rebels spenaer is foroed 
to conode. "lot exre they are very velfieunte and hardye, for the wot pert creat ondurore of oold, Iabour, hunger, and all hurdiness, rory oot-

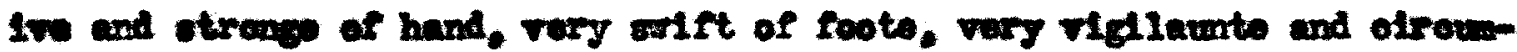

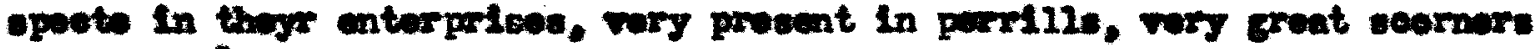
ar ath."

The "outraglovi ory" spenser descoribes an "a torrible yoll and hubbabem, as If hodven and earth would have gene together". Maloger "all in carma thin bedight," and the oative motohos in their rags, I1wo

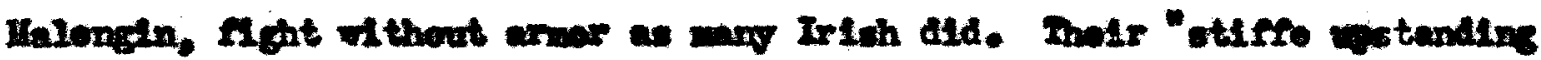
houres" wor thatr staring eroe revemble the Irteh "gilbbes". The vilI0In wanding around the kighte reoull the robele in "theys oonfuaed dime of marwhe in hoapes, Ththout any ordor or arrw, theyr oleshing of

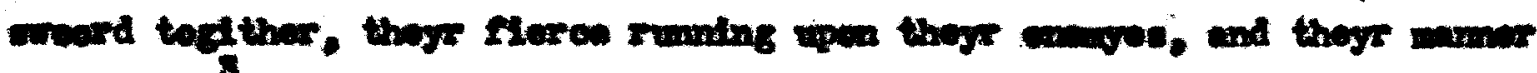
of reght."

Then they returned the noxt day, "Bvoryoue ald be and arrers beare," and "all att onee at him lot Ply theys Nuttring arrewes thloke al flabe of ancur" The Irish kernes, Bponser says, had "short bowes and 11ttle quivere wth thort bearded arremes."

mo introdustion of the rabble aren Into inightiy reanno is

1

Ies. P 70

2

ML. P 701

3

Iold, p ros

4

mes, pes 
not ocmpletely on Innovation fith sponeer as Mas Gray belleves. but

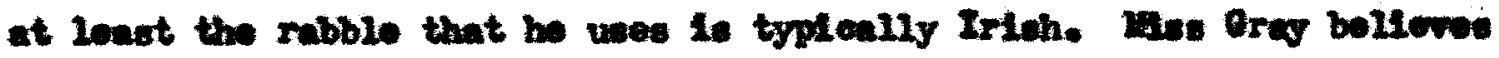

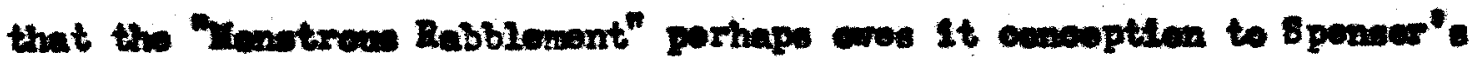
meriedge of the Munater Bobelliene Cortalnily the plotwe of Nolegor,

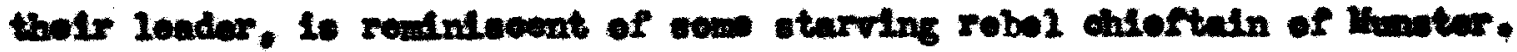
Ho 10 a pororfully bulit man,

"But af woh subtile substanos, and unoound

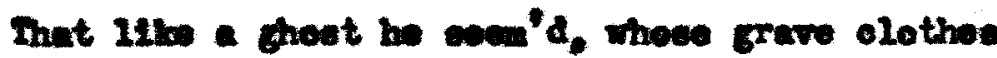
were wabound." (II, xI, 20)

"As paie and wan wo eabos was his leoke, Ils bodle lews and poagre as a ralos, And old all withered 14 we a dryod rooke. Thereto as cold and drory as anke. That seom"d to tromblo ovormore, and qualse:"

$$
\text { (II, xi, 22) }
$$

This is the poetionl worelen of the proes ploture of the starring Irion

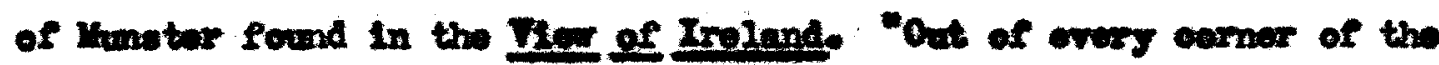
weoles and gllmes they oute oreopling foorthe upen thoyr handes, for thoyr logses could not boare thoms they looked Iike anatompes of death,

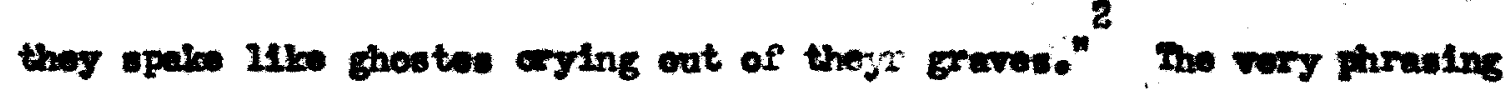

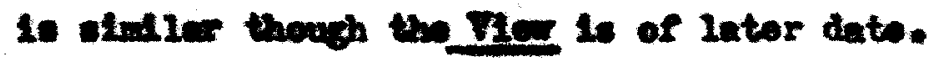

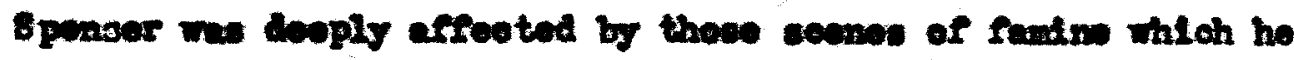

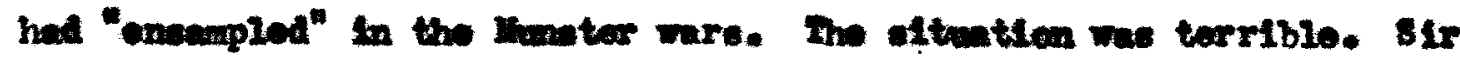
1

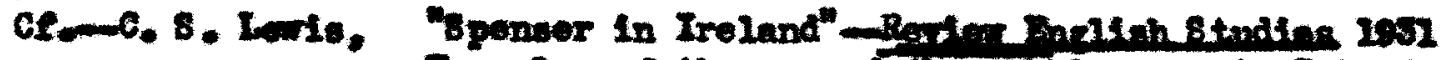
Krampios of the weo of the rabbio reut in Belardo.

2 Vien, 804 
Warhen 8t. Loger in a lettor to the Qroen rolates that not low than

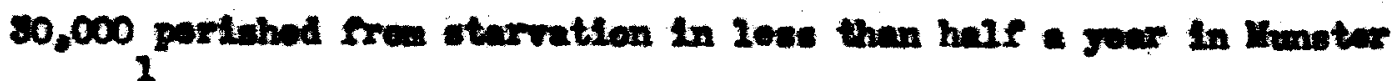
alone. The Peorte Qveene $20 \mathrm{~mm}$ of Ngares bearling the tolling wark

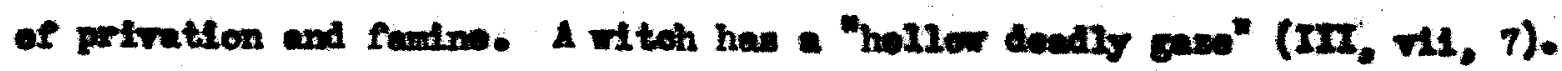

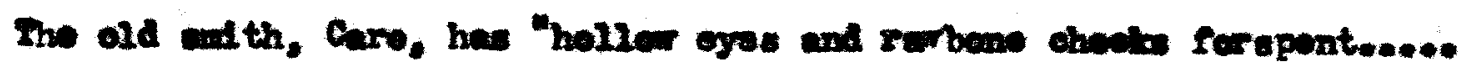
Wth ruasod beard, and hoerte shageve houre, The wloh be novor wont to cembe or comsly shecro."

$$
(\boldsymbol{I}, \mathrm{r}, \boldsymbol{s})
$$

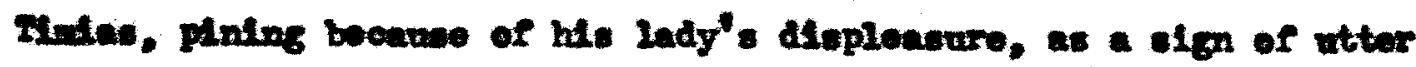
rretohodnece, is mado to rosemble the starring ribels

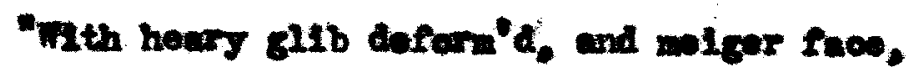

Uko poot late riven frem his grive agrge'd."

$$
\text { (21, 211, 22) }
$$

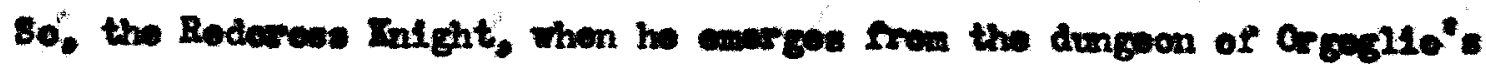
oastio epeales with

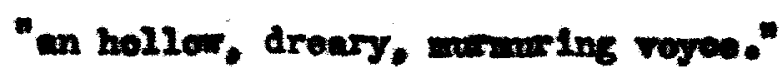

Bts" "fwoble thighes, whable to uphola

HIE pined oares, him seares to light could beare.

A roverul spoctaele of death and chasty drore.

II. *ad dull ope doope sumbe in hollow p1to,

Could not endre thi wronted sum to riers

His bare thin oheobes for want of bottor bits,

And empty sllos dooolved of tholr dor,

Could wibe a stong hart his hap to rom;

1

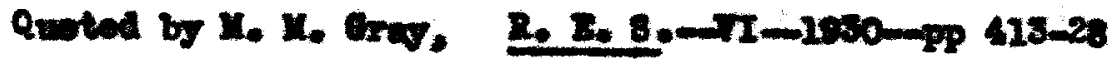


III rmbow anwos, whoee alighty brumed benre

Wore wonted to rive stoole plates, and bolwots hor

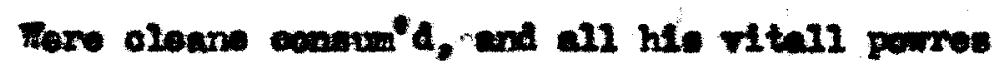

Deow'd, and all his neeh shronk up 11 be

$$
\text { Whored nemrea." (I, AII, 28, 40, 41) }
$$

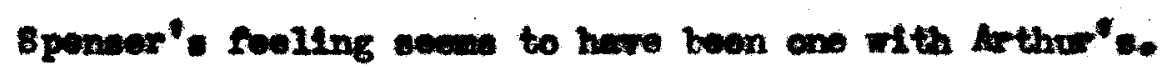

"Irembling horrer ren throuch ewory leynte."

$$
\text { (I, IL1, se) }
$$

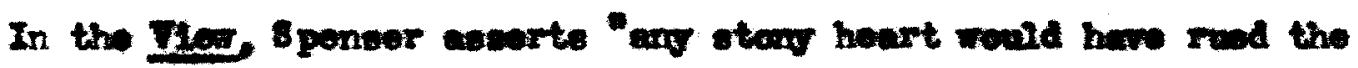
sawe;" In words almost Identicel wh thowe quoted abeve.

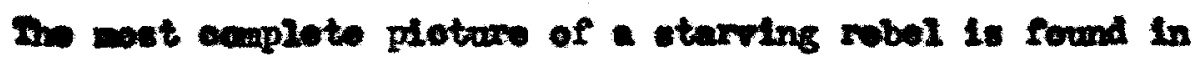

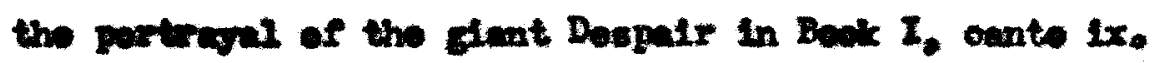

- mat sow Howa might

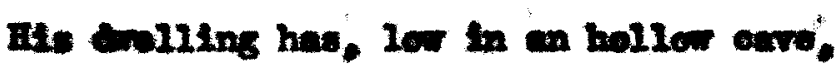

Dart, delefull, drerte like a greadle grwe."

Doopalr hlmele eat indelo.

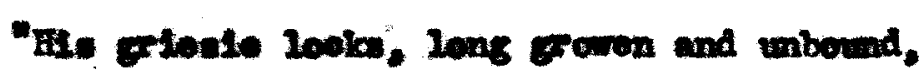

Dieordored hong about his shouldors round,

fnd hid hie twoes through wioh hie hollor ogro

Lookt dondly dull, and otared as axtorund:

IIs rombene aboliae, through penurfe and pire,

Wore shronke inte his imes, se ho ald nover alno."

Hi. garwiont nowght but way rassod clouts,

With thornes togothar plod and patwod was,

the wich his nalud aldes he wrapt ebouts."

$$
(1,1 x, 35,35,36)
$$


Pablford enle this posage one of the "porple patahes" 1

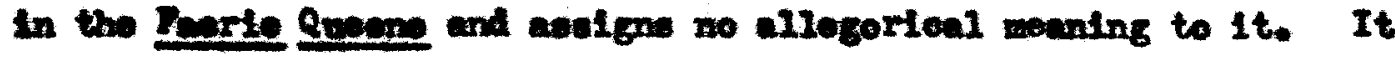

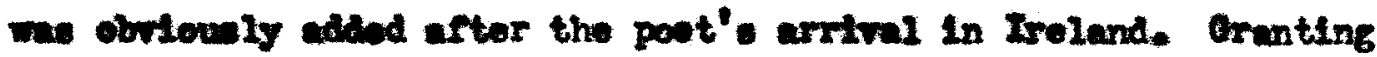
that the Ieerle Queene was otartad befere the pot Ieft Ingland. The firat three bolk were not publikhal for almogt i decale after sponeor wort to Irolend (1600). Speneer's wothod of reworking hit poews, and the firlew relation of woh paseages as the wo juet condidered indieat that the poot ineorporated in his carly work, bits of his intor sxporienee wich wonld, he relt, Iend strength and viddove to the nole.

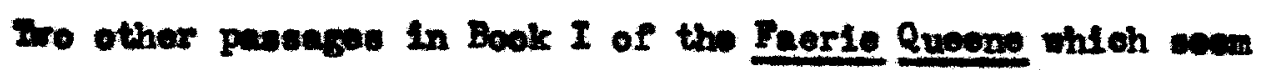
to ow werthing to Irotind, though lose dofinttely porhape, may bo

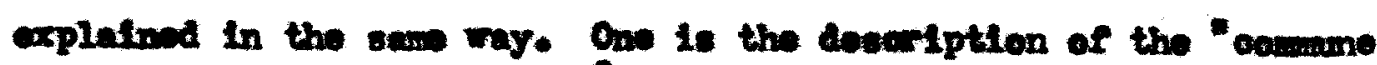

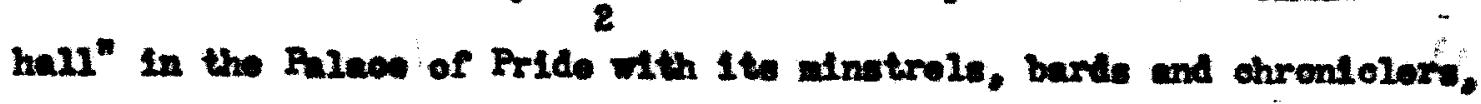
wich resembles the hall of an Irteh lord's castle. Sponser coens to have been eaquanted with the Barl of Armond ho alded the Bnglish againot the Deswonds. The dedleatory acrnot to Lord Ormond Impliee that

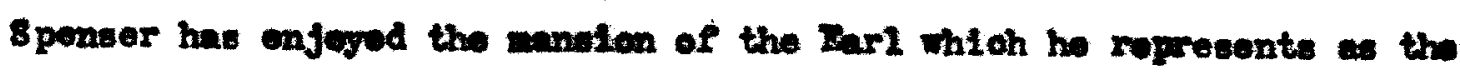
wole harbor for the thues in Ireland. If the ploture is not decived

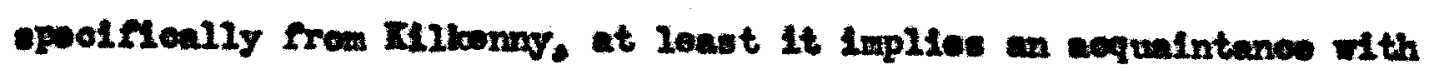
finter halls.

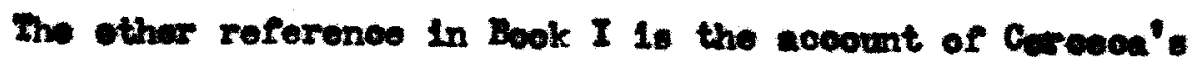
eotteg "under the etoop foet of wountaln hore" mich resembles on

1

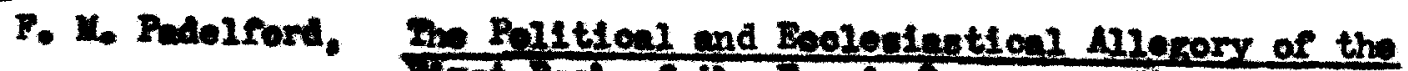

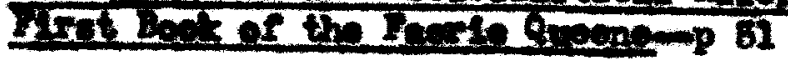

2 I. T. 3 
1

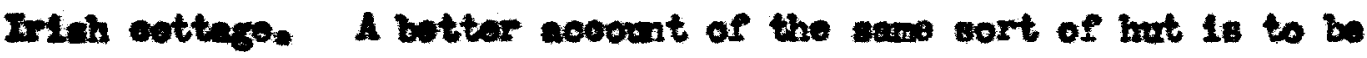
fornd in the pictore of the witch"s abode in Bodk III.

- There in a glocar hollow glon the formd

A IItio cotteg, bullt of athok and reodes

In howely wise, and wald with sede around.

In miah a wtoh did troli, in 1eathiy wodes

And rind want, all eareloow of hor nockes"

$$
(\mathrm{IX}, \mathrm{IL}, 6)
$$

The vanoevony equlior of some of the poorer Irish tenute 8 penser

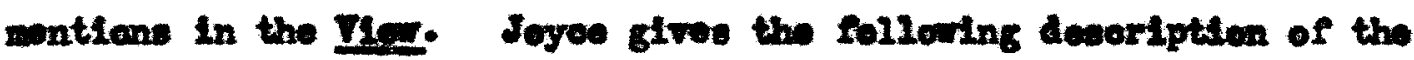

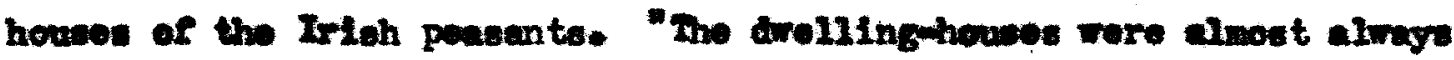

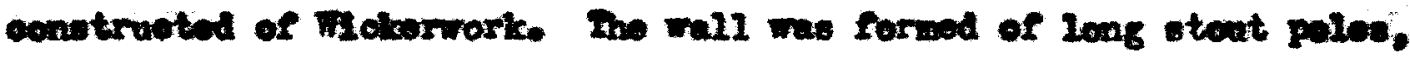
etending protty noar ench other, wth thetr exde flow coep in the

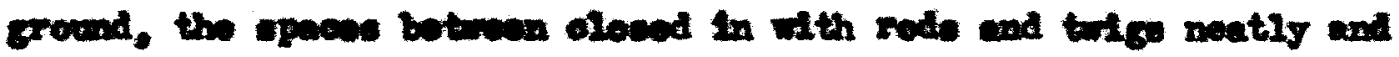

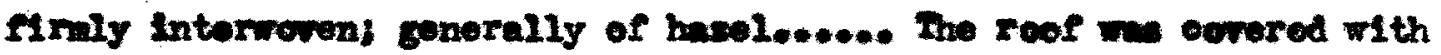
tror or rubes or rowd, or with thin boards of ook, Iaid and fastond

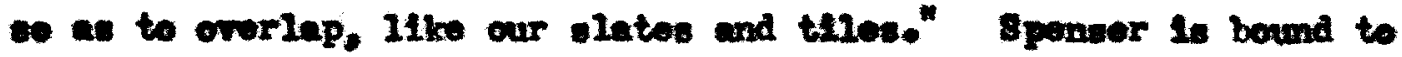

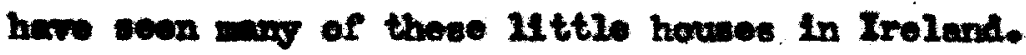

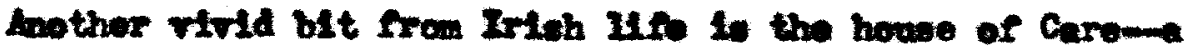
withy wth the inooswant nolee of hownore and ballows, fit habitation for Care. 8 mithe (Cobha) wore nuavews in lreland, and of hgh repute, and tholr art was highly dovelopod at a wry early portod as varieve

1 I. 14. 10

2 Der, p res

3

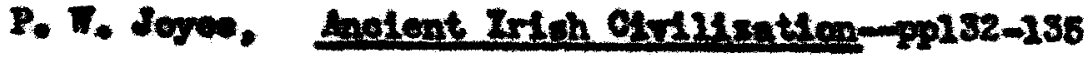


난,

1

anelont rollos tostify. Foniey think that Spenser on his travels with Orey bay have spent a night in evoh a place.

Thle ousta of sooidng harbor for the night in asties or oottages along the way is an old Irieh ovetom. Epenser asearts nore then onos that "there be no Imes" In Irolund where "1odging e horse woat or man' meat" might be obtained. Hoapitality mas not only a courtesy but oven a rellgtous firtue. In the records of 8peneer". IItigation with Iord Roche, the poet nocuses Roche of having kllod a "fat beef" of Tolf 01yvos. because H. Sponser ley in his heuse as he oame from the eventons

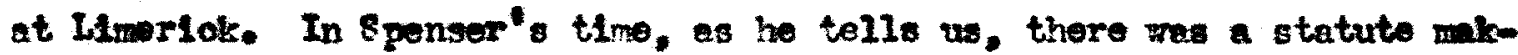
Ing It treecon "to go Into anothar man's howse for lodglng". or "to his cmo tenant". house to take Vlotuall by the wh not wthrtanding thore is noe other manes for htm to have lodging, nor horve mont, nor man' ant." Hay 1t not bo that the inhoepitality of Turpine is a rofieotion witeh Sponser wo bitterly deplored?

In the Faerle Queene the remectlone of Irelend thus fer oonstdored ocen prodaninantly those of land rackod by rar and fartne. 8noh "variete" as AtIn and Faror ply a fruttul trede; the harmers of relentlese Care murder sloep and "affilot to the very somle" Deapalr Gains oaby rlotins; and the Batant Reast pursues a ervel course in aplto of all the Fairy lonighte oan do. In Book $\mathbf{V}$, we have en indication that the poot's 21 fe in Ireland was not all horror and gtrifo, when wo have an

$\mathbf{1}$ r. T. Isyce, op. ofto-pp 132-135

2 P. Henloy. op. o1t. 125

3 ven, 772 
soocunt of Calleore's life anong the ehopherds. Inls passage is un-

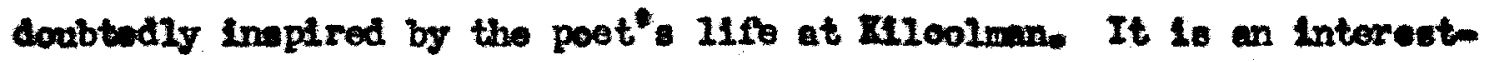
Ins ocmbination of the real rural Ireland that spenser lener, and an

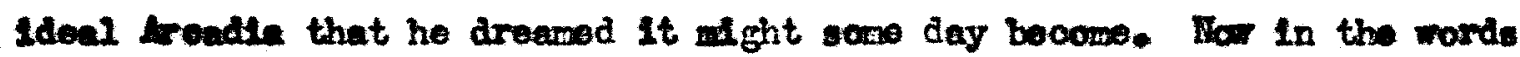
of Hollbos, now of Calldore, the poot soems to volice his arn sentisents. The ald thepherd recounts to the knight the joys of the pastorel ilfe,

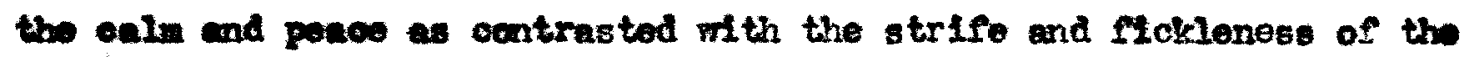
rorld. Is the poet referring to his am experienoe when lollbee saye-

"The tine was onoe, in uy flrst prine of years, Then pride of youth forth pricked my desire, That I alsdalned wonget mine oquall peares 5. foller sheope, and shephoardes base attire: For further fortune then I would Inquire. And leaving home, to rodall oourt I sought: more I did sell moelfe for yourly hire, And in the Prinoes gardin daily wrought. There I beheld such valnonesse, is I never thought.

Fith sight whereof socm oloyt, and long deludod With 1dlo hopes, which them doe entertaine, After I had ton yeares wolfo cxoludod Frem native home, and spent yy youth in vains

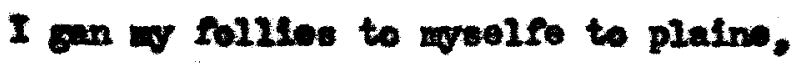
And this wroet placo, those lack ald then sppeare. me back returning to wy shoope againe. I frea thoneeforth have learn'd to love more deare This Ionly quift 119e, wiloh I inherite here" (VI, 1x, 24-25) 
Wron more Ille the poet is Calidore wo, tired of hit quot,

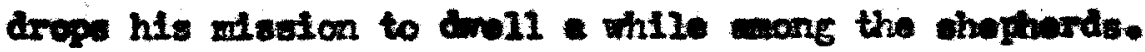

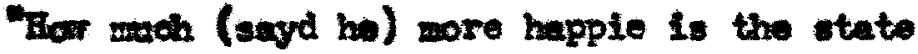
In which y father hare do arell at abe, loading 1 ife to troe and fortumate Pran all the terpeste of these vorldy seas, Wieh tose the rest in daungerews seas, Whore warres, and wrecles, and vicked onutite Doe them affict, which no won can appeace. Thet corted I your happliness envie. And wh w lot wore plast in such felloltie.

\section{I find}

That all this worlds gay ahowe whoh we edmire Do but valne hadomes to this safe retyre of 1ife, wich horo in loriinesse yo lead, Poarleses of foos, or fortunes wreckful yre. Thich toseath states, and underfoot doth tread The mighty onoe, affrayed of every chamges dread."

$$
(\mathrm{I}, 2 \mathrm{x}, 19,27)
$$

8 ponser wont with Ralejg to Lonkion In 2509 to have the firgt besics of the Brorte Qyeans puilishod and perheps with hopes of proforwent at court. In the words of Colin recumed fras Oynthes" oout he says,

"For gooth to Exy. It is no sort of life

For shepherd 11 to lead in that seme place."

$$
\text { (C., C. . . . . , , } 68 \text { ) }
$$




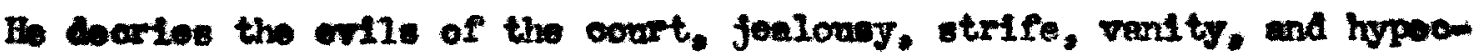
rloy- So spenser, retaming to K1Loolmen wast have welcomed the peace

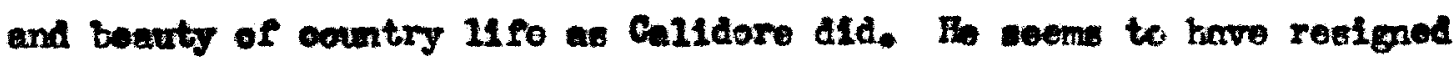

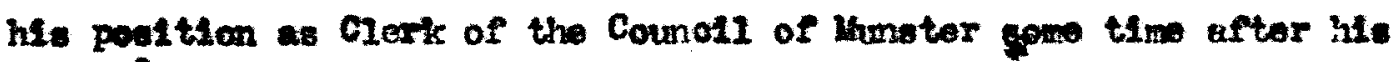
1

return and to heve rotirod into private 11 fe. In 2694 his marriags: to Ilixaboth Boyle took plece. These geers eeen to heve been happy owes for the port, and his pretoe of the rustic 11fe, though strongly colcred by ldeas of an Arcadi, seom sineore, and indicato that the poet is oontont wth his lot in Ireland.

Bven here the poet is not fro from the inroads of the rebels, however. The "Brigants" oome and ruin the comaunty and carry orf the shopherds. The traglo irony of this passage is self ovident whon wa inow that scerce tro yeary after the publication of these atenzas the Iyrone rebellion broke in hinster and urapped $\mathrm{x}$ lcolman in flames, faroing spenser to nee to Cork. Unllke the shepherds who were "foar2eese of foes" spenser lonen the dargor that menaced the planters, and

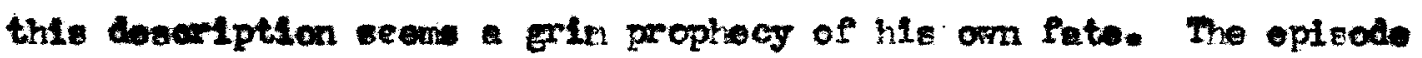
ende. horever, rith note of optimien which is not found in the Intor Mutablilt Gantos. Pastorella is recoued from tho "brigents" and returned to her nowly diseovered parente. Spenser here soows to feel that Ireland will be delfvered from the relen of rebollion and restored to Dngland to whon the rightfully belongs. Milo wad spenser' drean for Ireland. Be deplored the rrotchedness of tho lend and if he seems w wivocnte mpre rrotchotneas, it is cnly because that was his idea of

2 R. F. Ouwroh, op. oltamp 166miglve date 1598

2 F. I. Carpenter, op. oft, $\rightarrow$ 20-gives date June 11, 1584 


\section{7.}

the only way poentble of earing Ireland. Ito aronmed that wome day it

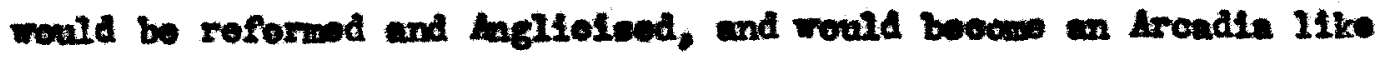
Hollbes"s before the brigande ruinod it. It is truly Irosacos when he deelares that he hopes by the theorles be adroontes "to cottell an oternal poece in that country and eles to mike it profitable to her Injoatie."

1 IIS. 820 
GRAPIER IV

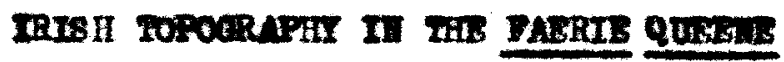




\section{RELAND}

in the

Sixteenth Century -
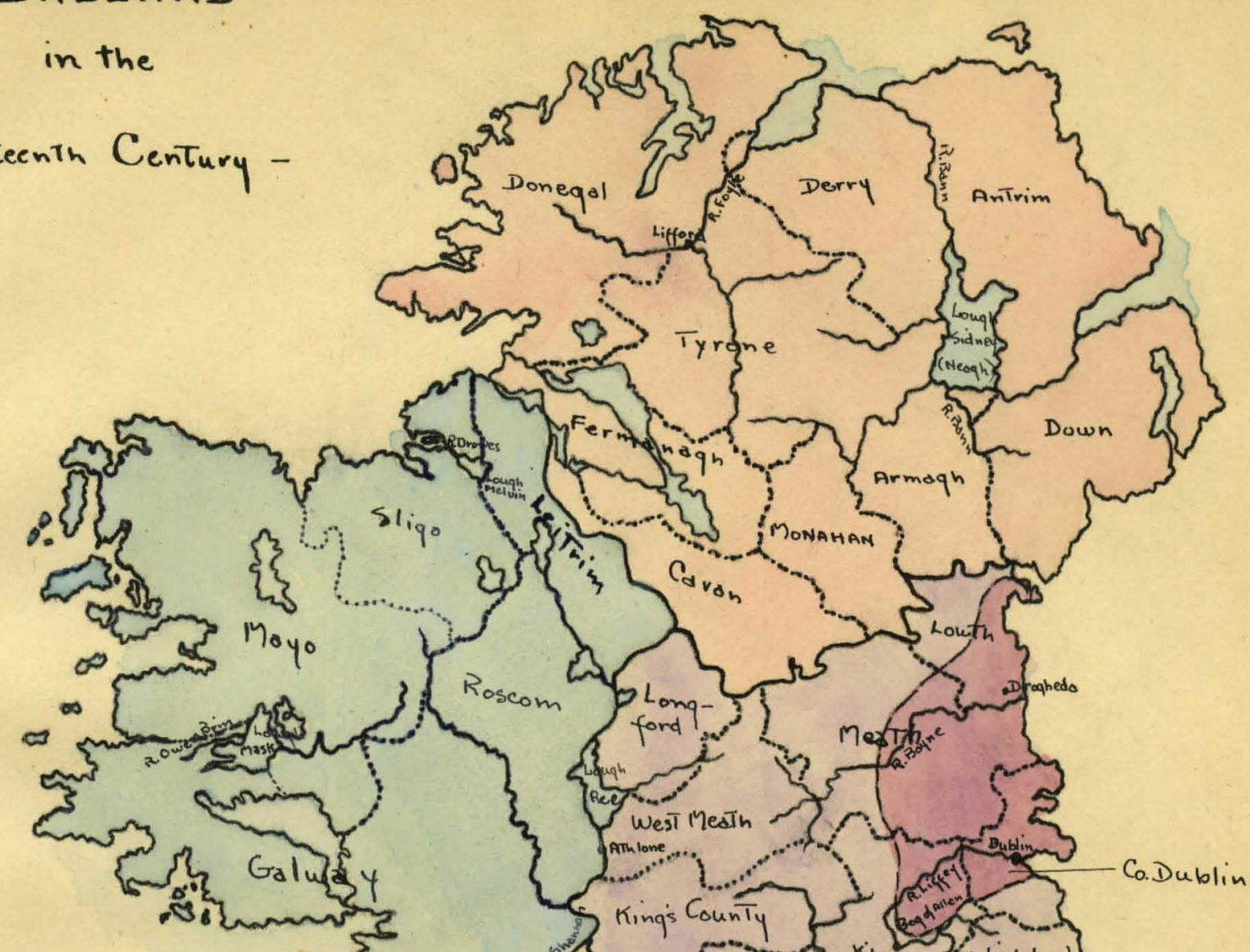


\section{CHAPTE IN}

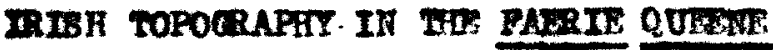

On of the moot motable of sponsor" trate as a miter is

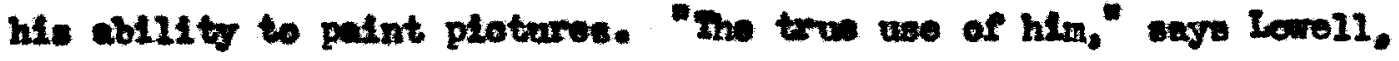
"Is a gallery of piotures which we visit when the mood takes no....

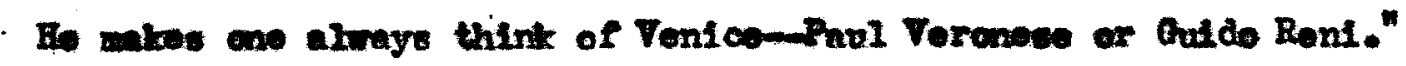
Thomas Campbll has oulled him "The Rubene of the Poots". and Carponter 1 eemparve hin to surnor. One oannot rall to note the otrokes of a

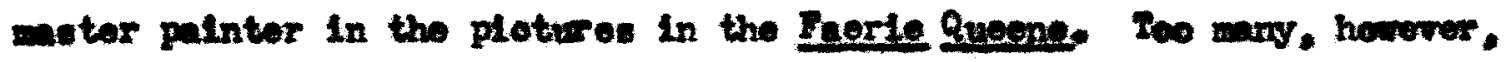

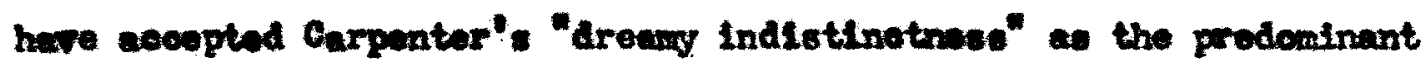
ohmeteristio of the wole oplc. Fasiltt, for Intenos, sars, "Bpenoer's potry is all falry 2and. Wo wender in mother world of ldeal belngs-by the sewnd of seftor etreans, anong ereenor hills and faizar vallege. He painte natire not as we find $1 t$, but as re expeotod to Find 1t, and fulfils the delightful prowees of our youth."

At Arst glanoe, we my think olortan's reala indoed a drean Iend there nothing is real, where even troes and hills are fllawents of the poet's imagination, but this is to lose aight of those intrustons of reality into the land of shadow, which gran wore frequent as the story pregremes. To be wre, it is a falry land, and justly so, bat it is a falry lend wion ewes woh to the land where the poet 11ved. If Ireland

1 Cr. J. B. Metoher, "The Painter of the Poete" - g. F. XIT $\rightarrow 25$ 2

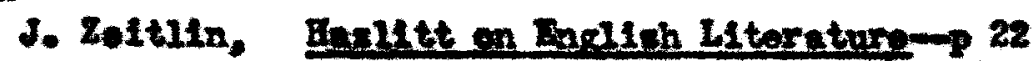


offered sponser explodta for his inlghts, she also presented him the Fld and untasod magnifloenos of forest fad plain adnirably aultod as a baokground for doeds of prowess and ohtvalry. hs Legouls has satd, A cowatry of thoweand enchantwents, w11d desert indoterminato rogion of Imenee forests. Bpencer drem it largely from the sarage land of Iroland, whore his dresms could all but grow real and observation conia rovivo ranoy.

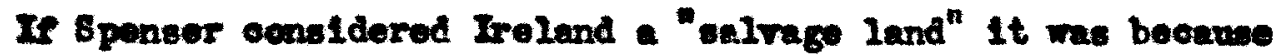
It was "throagh long wire left almost wasto", and "through bruthish bar,

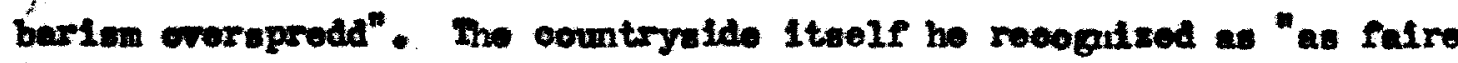
a Ind as way be redd". In the Vier his werds in referenes to the Dorth of Ireland 111ustrate his epinion of the beavty of the wole Iand. "And oure it le yot a nost beautifull and weot countroy as any is under howron, coowed throughout with waw goodly rifors, replentshod with all sorts of floh, most aboundantly speinklod wth wany oweet Ilandes and goodly 2nkes. Ifke 14tie Inlund sease, that w11 carry oven ships upon theyr wtors, edomed with godly woodes Itt for building of howes

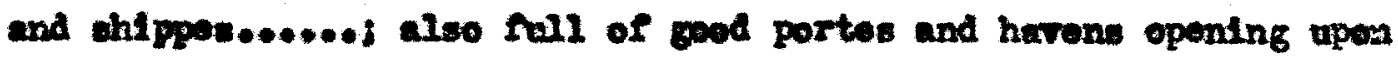

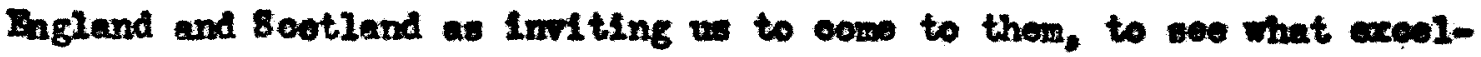
Ient oowditles that countrey oen affoerd; besides the sogle iteelf is wot fertile fitt to yoeld all kind of fraits that ohel bo coudted

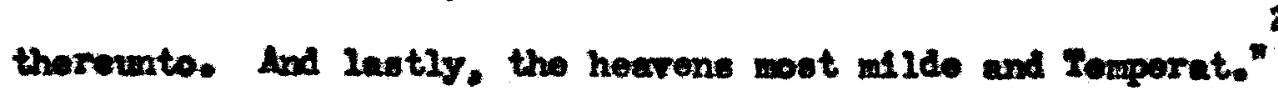
Letwal Irith place nawos appoar in the Fatry land that sponeer ereated. Othar lecations are given nowes by the poet, and, though they 1

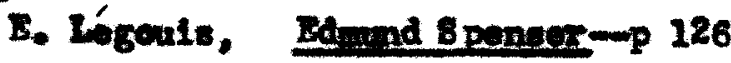


soem forelgn to modorn geography, they are dortved very befinitely fres Bponier"s knowlodge of Ireland. At times the desoriptions have a tone of almost homoly reallty, agaln they are nore ideallzed, but there to alrays that actracy of cotall which denotes been observation end lends adrtain vivid and compinelng quallty to the landsoape of the romanoe.

thong several passeges contalning Irieh pleov names, one of the most outstanding is the catalogue of Irish rivers attending the

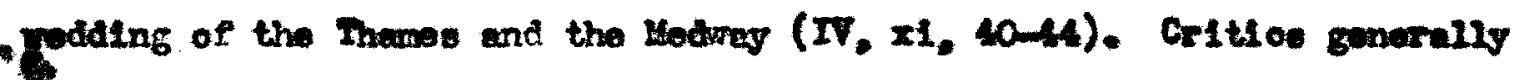
agreo with Professor Osgood who attributes to "the poet's familiarity

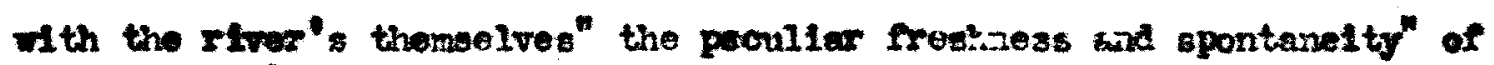
1

the paseage. He has shom that the names and opi thete of the Daglioh river: are Arived largely frow Holinshod, Camilen and oontemporary mape rather then from observation. In a letter to Farvey in $1580 \mathrm{Bpen-}$ ser gives an cutline of the Bpithalomion Thareate, one of the lost poevs, which is thought to have been derroloped into the river catalogue In the Iexin Sxeane: Fore he coclares his intention to cesoribe all the Faglish rivers at the wodaing, but makes no wention of including any of the foreign rivers which are found in the later oatalogue. Ho colnomledges here his dobt to fiolinehed. Ho definite literary source has beon discovered for the cetalogre of Irish stroams, and it soves Frobable that he added these guests to the ciglnal list after he went

1 Cf. X. E. Hoolson. "Rovlistlo Elewenta In Bpenser"s 8 tylo"

2

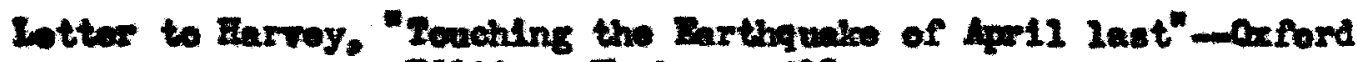
Dationm Irster $\rightarrow 2$ 
to Ireland, and rollod an his am knonlodge for tholr deworiptiens.

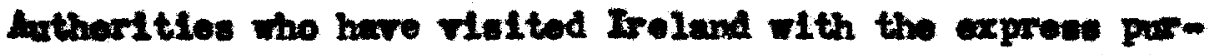

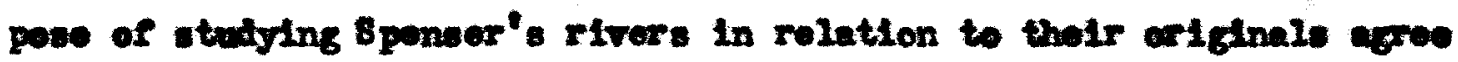

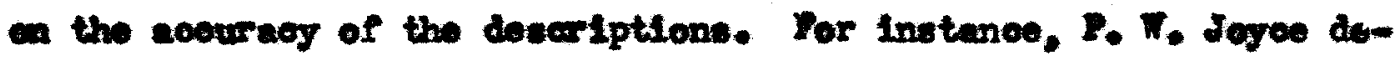
alarest "The arynese of a nore catalogue is relleved by the happy

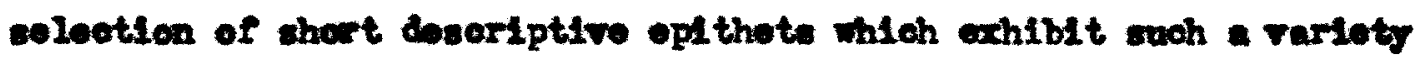

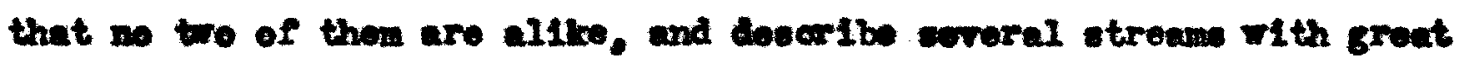

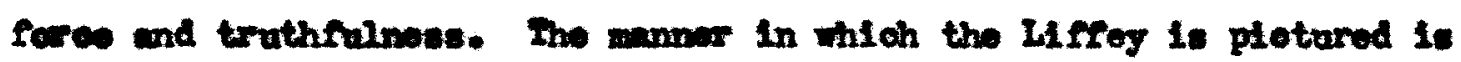
axrewely jumt and natural, for this rivar. arter bureting trom the

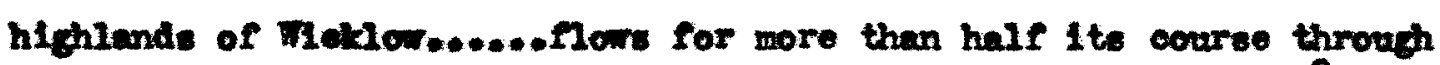
the lowellest lea lends in all Ireland-the plaing of rudare."

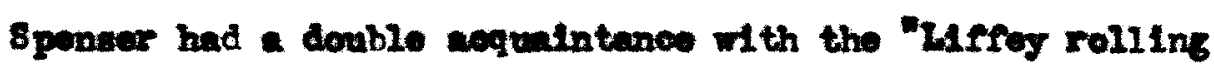
down the 1en". Bo ow it as it flowed by Dublin more he 11 ved for wost of the time betrewn 1680 and 2688 . On August 24,1682 , he whe granted the lease of IN Abbey. County KIIdare, and for the noxt tro

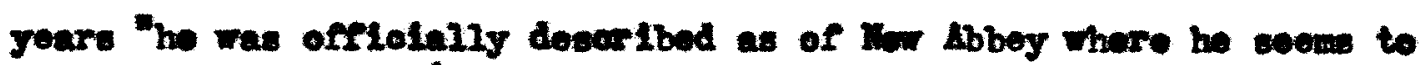

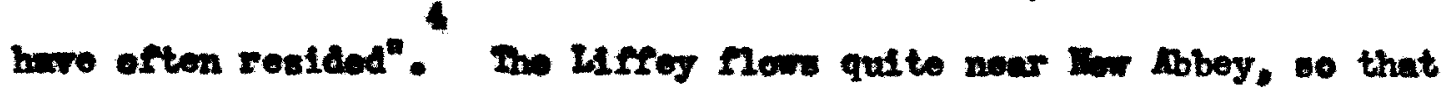

1

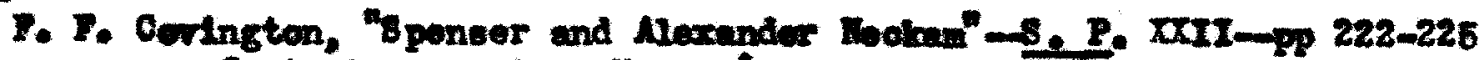
Corington mentions Doolne's eatalogwe of Iriah rivers in the thira "Dietinotio" of De Ludibe (trolfth entury) whioh sponses Aft have eom in manustipt or portions of it guoted in tho 1680

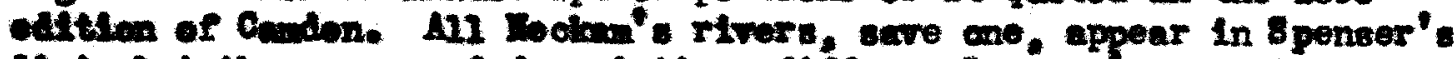

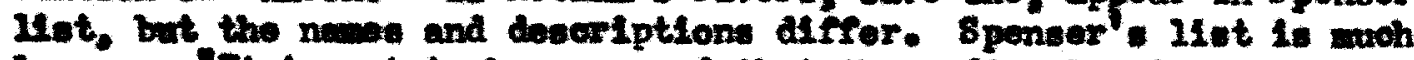

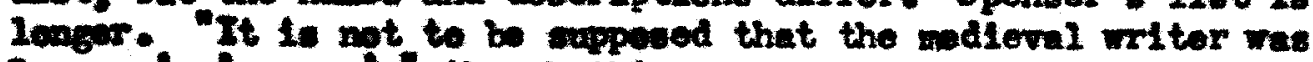

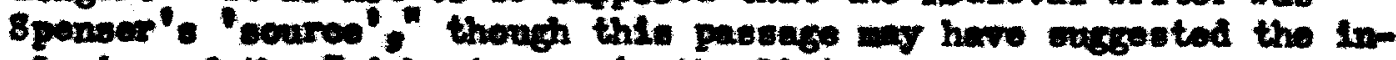
oluaten of the Irith streams in the list.

2

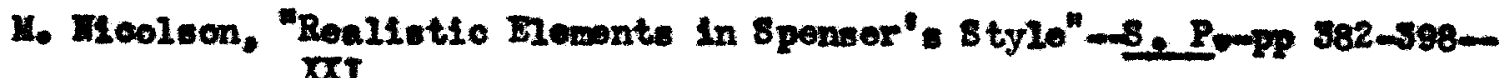

3

Bisabeth Fienta, 5969, quotod in Garpenter-p 27

4

Dotaonary of Dationd Boxrephr 


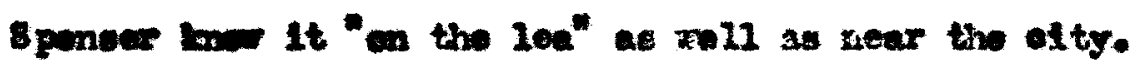

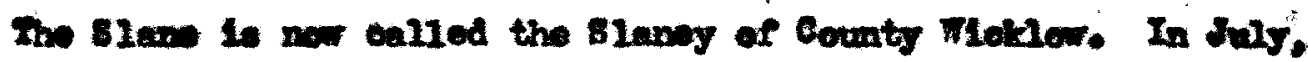

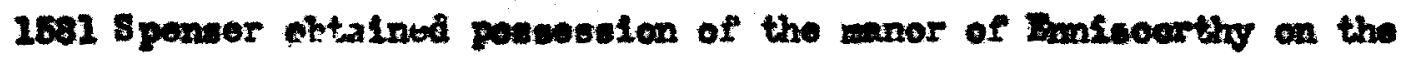

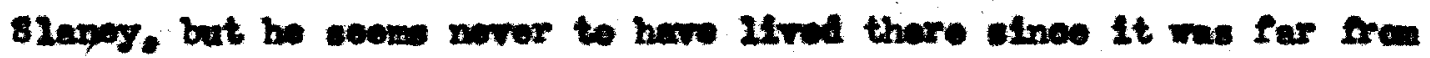
Dublin, and the records show that the property wre turnol oror in Dacomber to Rlohard synot. It soem nore probuble that 8 penser learnod to know the rivor on the expedition with oroy to Ononmalure.

mere is sowe dispate as to the Identifiontion of the labrien, for there is no river by that newo in Iroland. Malkinor oalle it the Orenbrin which nowe Into Lough liakk, and to whioh the opt thet "stony" 1. applicable. Bponser got his Information from Englith soldiers from

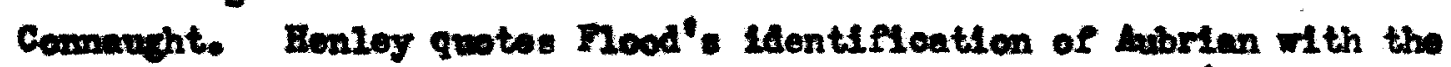
Exin, a rookg tributary of the 81 aney in County Wextord, but is not complotely satlefiod. Ialghtley woom the wont eartain of the throe, and ho 1s experted by Dr. O'Dinerren whos he oonalders "the Coryphaeve of Irish coholars and topegraphers". Ho belloves that the Aubrian is tho IIng'. Aiver, a tributary of the Liffey in County Kildare. Erey 2ed his treope dow the ridge abore this river on the way to Glenmalure, and spenser rould have seon the rlvor then. The Irioh nawe was "Mrenree" (Mhan righo) which spenser ade into "Aubrien".

1 Eisobeth Fince, 6968, quoted in Carpenter $\rightarrow$ s

2 4. C. Muliner, Elinbursh Reder-Jasnury 2905, ip 164-280

8 A. C. Fulliner, op, olt.

4 P. Bonlog, op, oit.-p os 
The "Bhopen" Is shamen, and a glenos at a map will prove the aptnees of 8 poneer's phrave "upreading 21ke the sea". Iponsor's dutios as Glark of the Cownoll of Munstar would have oarried hile ofton to hime1

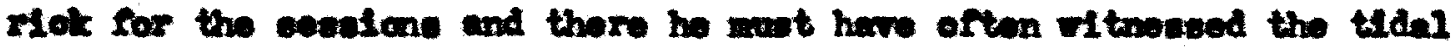

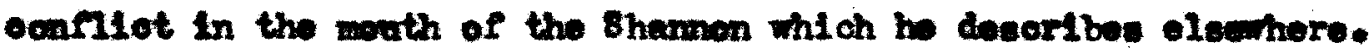

"Lik we the tide that ocwos from the Ocoen mayne. Mowes the shenen with centrary fores, And overuling him in his own rams, Drives backe the ourrent of his kindly oouree And selos: It soowe to have some other sourse: But whon the nood is opent, then backe aguine, H1. berrened waters forst to rodisbourse, Ifo sonds the sea his onne with double gaine, And tribute ole withell as to his soreralne." (II, 111, 27)

The "pleawant Boyne" is a river in County Boath whioh flons by Droghoda and Into the Irieh sea. Tho Bam risos in County Down, newe into Lough 81 dney (Lough Iengh), then forming the boundary betwoon

1 P. Henloy, op. Olt. - p 49

2

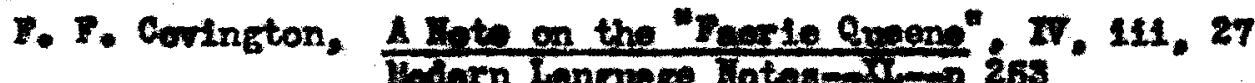
Citos a noto In the Amale of looh of for the your 1606. "The otroam of the Slenaim (Bharnen) terred back to Loghmigh (Lough Ree) and It was trenty-forr hours in that order, in the presenoe of all whe wore in Ath-tuain (Athlono)."

Hing it be that this olaborate simfle of spenser's had ito erigin in the impresetion made on the poet's mind not by a dally though Impreasive phonowonon, but by en unuevel and marvollous ovent, the wewer of which was etill fresh in the south of Ireland?" 
Countles Antrins and Dorry, Flow north into the North Channel.

burte Amiduf, which of the Bnglish man

$$
\text { I. on"do Brolue water" }
$$

Is the Diter Blackrater wich flowe into lake sidney post of the Bann, not the rtver of the sem neese in Cork noer Itloolman.

"Tho Mirfar deop: writes Dr. O'Denovan, "I tale to be the Faves for in some old mape of spenoer". timo, It is oulled "tho

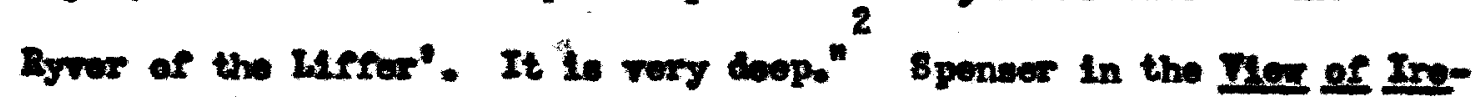

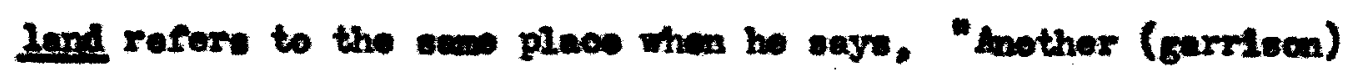
would I patt et Caetleliffar (Lifford) or there about soo as thoy abould have all the passages upon the river to houghrogle."

"Bad Trowl" Is a chort river which carries the waters of

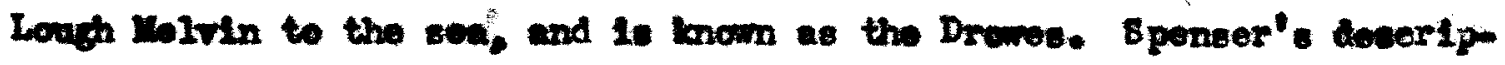
then, "that once his poople overren". showe that he whe sequalntod with the logend of Lough lalvin. Mooording to tradition, many conturles befors the Ohristien ore, the oudden ries of the Drowse, orernowing the lind and poople, turned the valloy into a 1mbo."

The 1210 Is a river Foring Into the Hunster Blackrator. Henloy sacesta, horever, that 8 ponser is reforring not to the tribertary, but to the Blaciarater 1tself, inee the maln streas and not the

1 I. Iolghtiey, op. olt.

2 nold.

3 Vien. P802

4 P. Bonloy, op. oft.mp 92 
Allo "tombles from Blowlogher steep:" (SLieve Loughera, a moorland alstriot in Imery). In support of this viow is the faot that in the

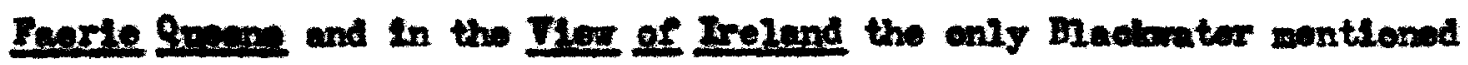
10 plainly the river of that name in vister, and no wontion is made of that Blackrater which Howed so near the poot's howo. In Calln clonte

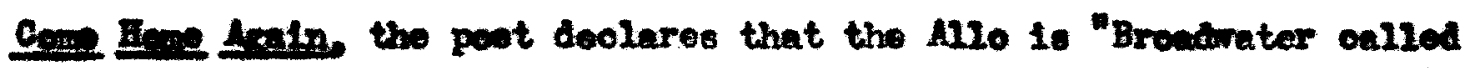
furro". mothor Indioation that the Mle is the Blackrater, wioh wae

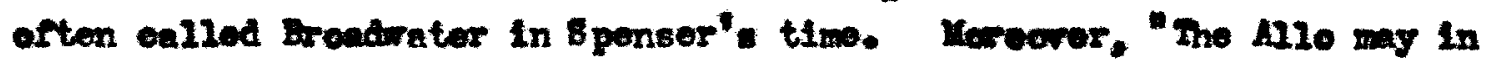
enciont times have been the newe of the main stroam, end thus the IrIsh entiguarten, Dr. O'Donomen explains 'Xallow', or Moynllo-m the plain of Allo. $*^{3}$

"Hulle mine" is the Abeg (Aran-beag-ilttlo river), enother telbutary of tho Blackantor mioh flowed near the poet's hose

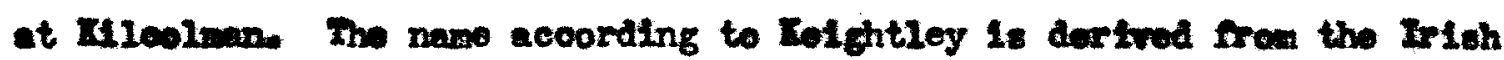

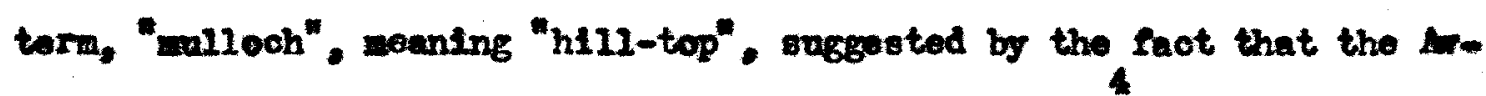
beg flwo in the Bellyhoura Fills north of Itloolman. Spenser declares that, he "walow" taught his Mulla's wewee to wop. Benloy think that

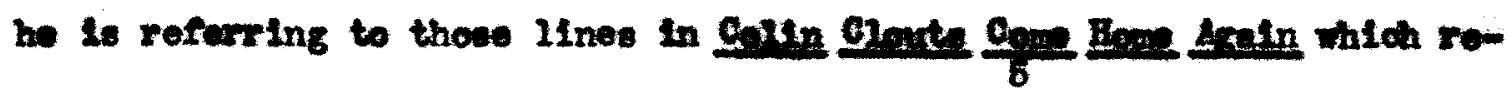
present nature wowining for har absent eheghord.

1 P. Benioy, op. oft.m 87

2

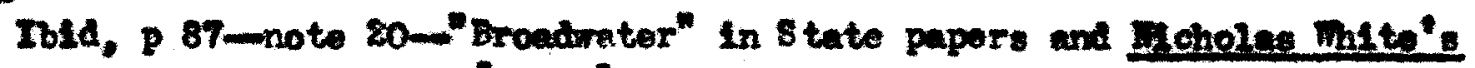
Jomenal

3

Ind, P 87-note 22

4

I. Iolghtley. op. oft.

5

P. Henley, op. 01t, $\rightarrow$ p 80 
The runilng watere wopt for thy retarne fal all the Alow wth langore did lawent."

$$
\text { (11, 27-20) }
$$

In the Buthalention. Sponser lovingly oelobratos the san rivor.

To Fyaha of kulle wich with careful hoed

9. allver soaly trouts toe tend Sull will

fud greedy pllos wioh use thervin to food

(Those trouts and plloe all othere deo wroed)."

$(65-69)$

sponser" pride in the placatory exeelienoe of his etrean is not a

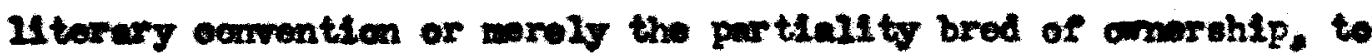
judge by nocounts of the river frow other eowroes. Cenden epoaks of

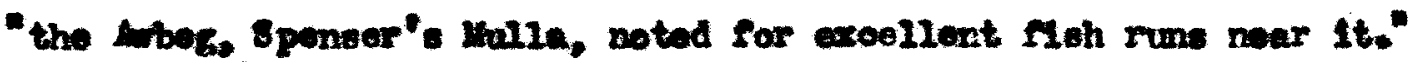

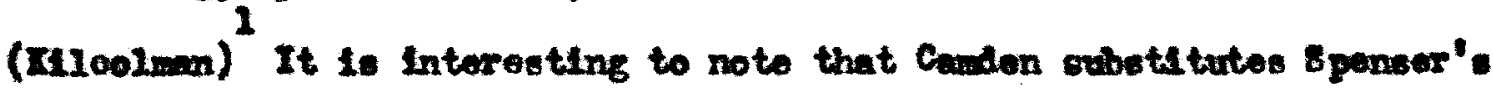
nave Haila for the original naue of the river on his map of Ireland. 4 modern tranel guld atates that the stream is ot1ll knom for Its fin tront.

The "three rencmed brokweren", the shure, the fowre, and the Barrow. are three rivere mioh how into Fatorford Fabour. Oniy the Worre (bare) of these three rises in the slieve Blowe lowntaine, but sponser indieatos that all three originate in the Nountaln. Kolghtiey

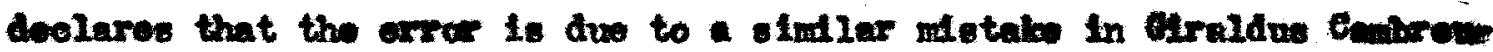

1 T. Canden. Estumis, Vol. Tr-p 276

2

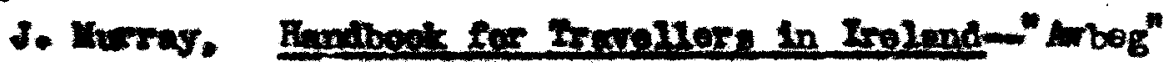


1

10. Bponsor ny haw proserved the old Idea parpesely in order to not the 2egend of the origin of the riverse

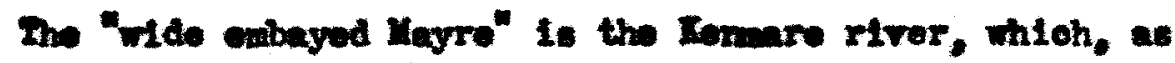
Kalghtley says," is ne river at all, but a bay or am of the wea rum-

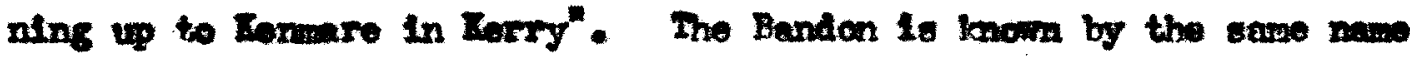
teday. and wo also is the Lee, winh

\section{Hiso an Iland fayre}

Bholooeth Corke with his dorided Food."

Ork tody has grom out ento the wainlend, but in sgonoer's day woot of the ofty ma probably on the 1elend. Inls is that sems river Lee on which Pollente and Hunora mot thelr fate.

The buleful Oare" presents the met difficult problem. Benley. on the authority of Jayoe, bellowes that it "ropresente the

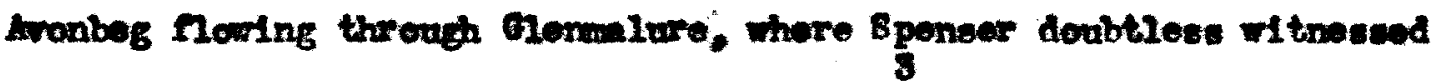

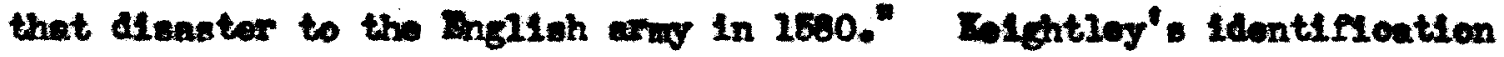

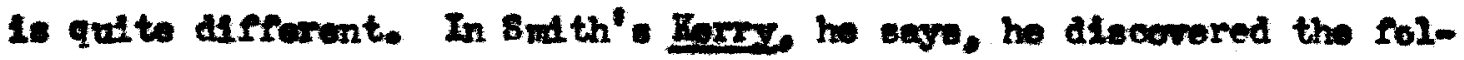

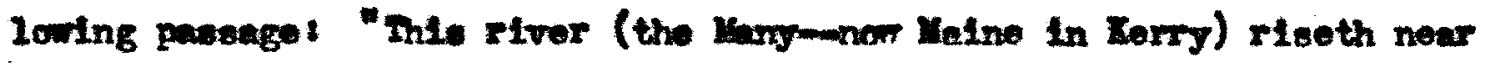

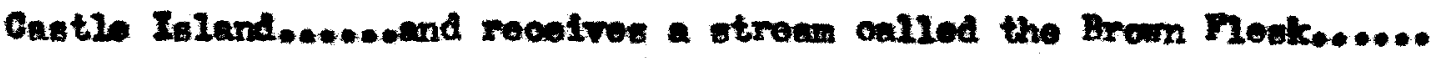
This lattor is conalderably euguonted by another oulled Qreach." - 41 seewod nem plain onough, bat Dr. Romen asoured we thet to his oertain knowlodge there was no ouch otream, "but," beis ho, "way it

2

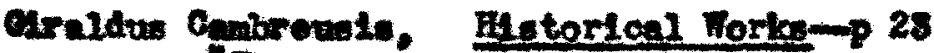

Thiree woble Fivers. then, Fise at the foot of the Blendine

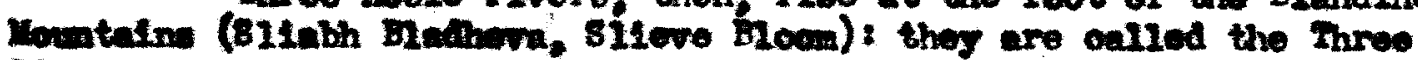

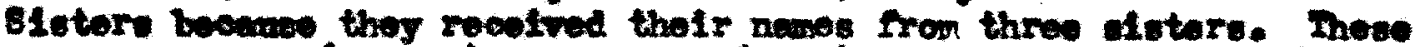
are the Barlit (Burrer), the sycres (Noro)

2

I. Dolghtrey, op. oft.

3

P. Ennlog. op. olt., p 92 
net be the Bram howk iteelf whese nome in Irteh is Oannmradh. Brom River" This wes quite decletve: Oawnrwath (pronowoed Ocan-

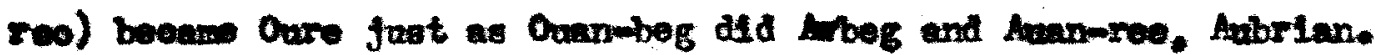

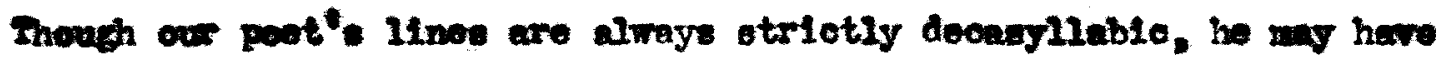

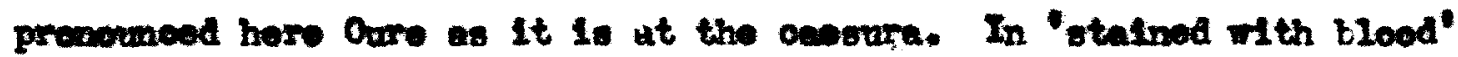
there wa be allusion to the nuse of the Hiver, as noll as to the engageant of tha Baglioh with the followere of the Barl of Dosmond wose onief abode was in this distriet." ${ }^{1}$ There is sem support for both thearles, but nelther seoms ampletely atisfuctory. or all these rivers. Mlo and Hulla mino" more cearest to the pot's hourt. Inoy wore familler from long eoguaintance, for thoy

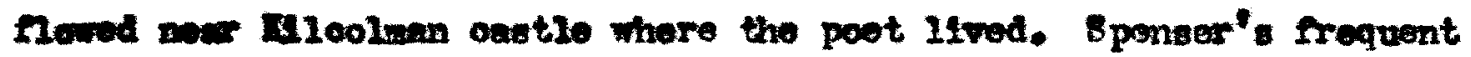

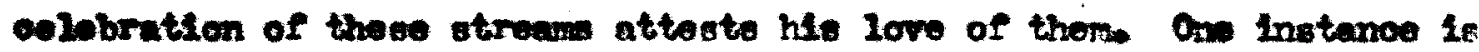
found in the lay of

Mralla fatro and bright

Dito whoee bed false Bregog milome atole That Shepherd Colin did condole."

Breges is that andl rtrow of the veme nara vition flow on the east of Kiloolum to join the Abeg on 1 to couree toward the Blackrater. The fact that Bregos must eteal andorground to his belored to lade ond Father lole wo has dotined his danghter for the luckless 4110 . is an allwion to the fact that the Brogog einls from alght for about tro wlee in ite ecares, leaving the bes quits dry euve in rainy wother.

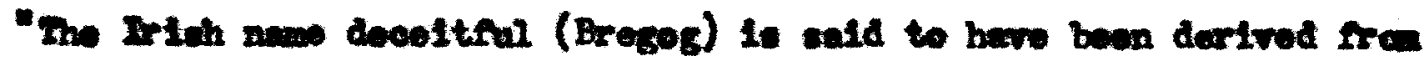

1 T. Tolghtloy. eport. 


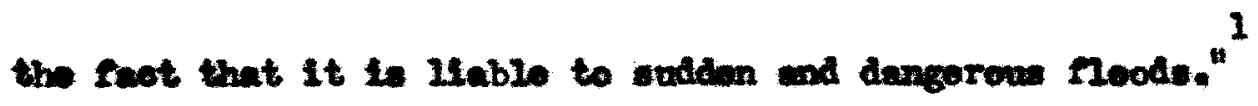

ad Father Yole reoolves more attention in the Intability

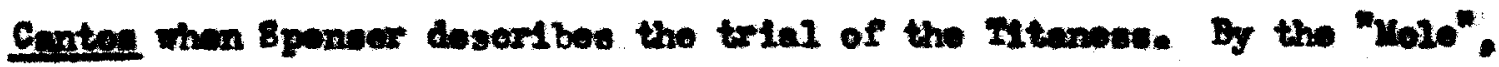

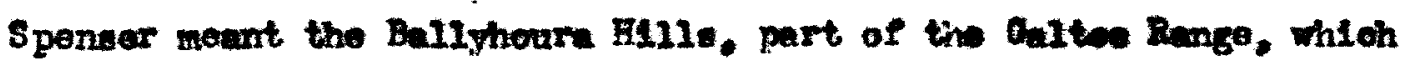
ofreled to the north of Aloolman. The poet pute all hIs love of tho h118 in thoir epring attire into these linos:

- And vole himelf, to homor hor the more.

Did dook himolf in frochest falro attiro.

And his high howd, that secueth almatos hord.

Fth hardenod frosts of forwer winter"s ise.

He with an Oaken giriond nom did tire.

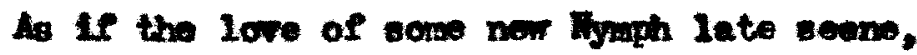

Fad in hin kindled youthrul freah deeire,

And made him change his eray attere to greono,

Ah gentlo Xole: such joyrano hath the well beveone:"

$$
(c, \pi x, 12)
$$

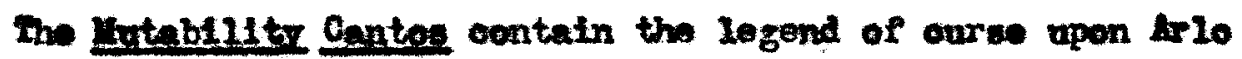
hill "the htghest hill (In all mon' olght) of 4 old Fathar Hole".

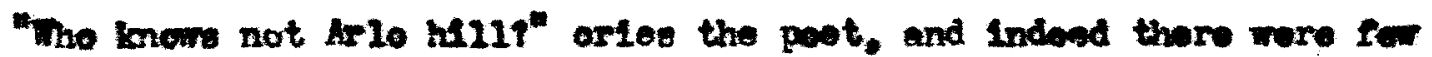
in Ireland who ald not mov it, end it wes not unimown in Baglend. Hano rous reforenoes to Aberlow, Abarlo. Rarlow and Harlo in the otato reourds of the time show it to have been notortous as the dwelling of the Irich rebele. Bpenser meane by it "the highest part of the caltec

\section{$\mathbf{1}$}

P. Denley, op. aft.-pe 88-87

2

Cr. R. Hollwohod, Grentolen-2 $1-962$ 
range below which to the north through a gien or deflie runs the river

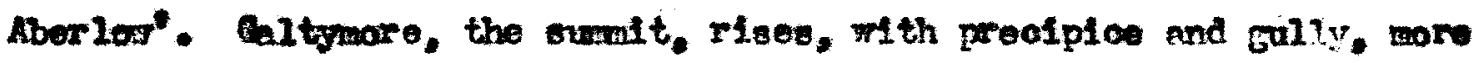
than 5000 feot sibore tice plains of Ipperary, and 16 som far and wide. It was connected if tir. the 'greet rood". the rild reglon of fornst, movm-

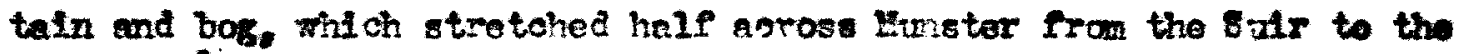
shannon.

In this pasage 8ponser colebrates the love of tro other lunster rivors. Holama, daughter of Hole and sloter of Malla, a falror Mood nay no wan ece". loved Fanchin or the Funohoon, a tributary of the Black-

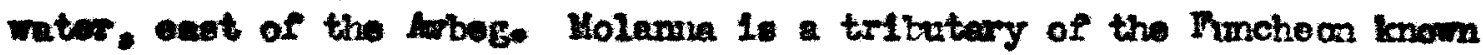
as the Bhamg. It has been cald that sponser got his nemo by olever combination of Iole with the last tro syllables of Bohanagh.

The passages considerod thus far contain personifleation of hil1s and rivors that Sponser know. Even more signiflaant then these 20gonda, though moh more difilcult of definite lentifl cation are the

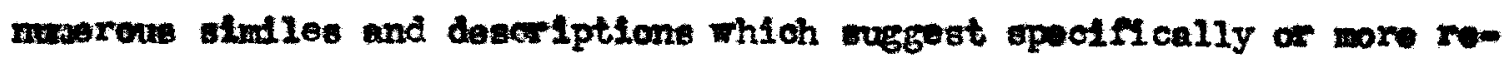

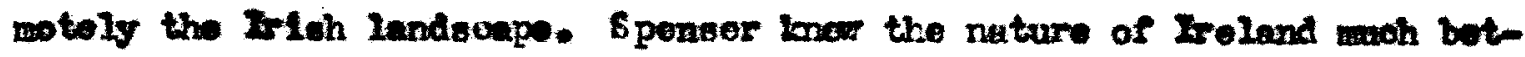
ter than that of Mnglend. In Ingland his 11 to seow to have been waln uban, eave for his trip north after leaving Cenbriage. A study of the descriptions he uses w11l shor that, on the whole, those taicon from real 11f and nature rather than from the classios and pageants end tapestrios, are clearly Irlsh in tone and color.

One of the most vivid sinfles in the Feerle Queone, an well as

1

R. W. Ohwoh, op. elt. 172

2

P. Bonles. op. oft. p d 
one of the moet ousily looktod is found in Book II, ounte 2x, stansa 16. Arthur and Groven are beset by a "thousend rillolns" outelde the castlo of Alime,

$$
\begin{aligned}
& \text { " Aa when a wrarme of gnate at croutle } \\
& \text { Out of the fennos of MIIen do arise }
\end{aligned}
$$

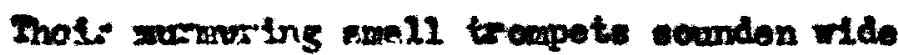

$$
\begin{aligned}
& \text { wiles in the aire their elustring arm nies } \\
& \text { mat as a oloud doth veene to din the eldeat } \\
& \text { Io wan nor bosat may rost, or tale ropast, } \\
& \text { For thoir aharp woundes, and nogrew infurles } \\
& \text { IIII the fiorce llorthorne wind with blutring blast } \\
& \text { Doth bler them quite wav, and in the Ooson oast." }
\end{aligned}
$$

8o rivid is this wth sound and fooling an well as with lwages that wo do not nod to be told that the poot in his low Abbey rosidenoe was quile noer the Bny of Alien, to rooognise that persenal experionoe Inopired it. The t1de at the mouth of the Shannon has already beon wontloned. tany of 8 ponser's deseriptione of forests are eoleced by his tnemledge of the Hunster woods. The narren ford "In the oovert" where Tinias was trapped by the forestors is typioul of many woch Irloh streause "with thiele roods over grame". Bolphoebe's abode whore Timias is healod of h1s wounds is acenthat glorifled ploture orwm from the roodland 1 haunte whloh sponser knom.

$$
\text { "in a pleaseant glado }
$$

Fith mountalns round about onvironed,

1

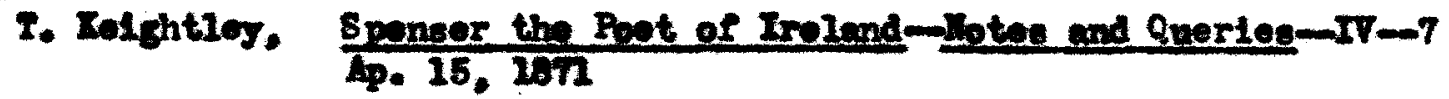


And wighty woods, which did the ralley thede,

And IIw a stately thontre It mado,

sproading itselfo Into a spattow pleino.

And in the wdot a little river platde

Bongat the pury stows, wioh soon'd to plaine

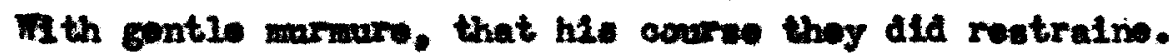

Bonide the eame a dainty plece there lag

Plented with mirtle troes and lavrels groene

In whith the birds weng wany a lowity lag

Of gods high prayse, and of thair loves areot toone 4. It had been an earthly Paradise."

$$
\text { (III. T. 3o-10) }
$$

Eonley has auceested the parallel of Curon's vogage to the Bewrer of Blise to the rogage north from the senware Alver around the

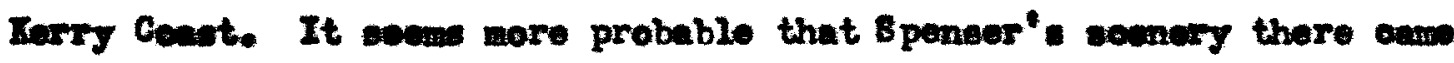

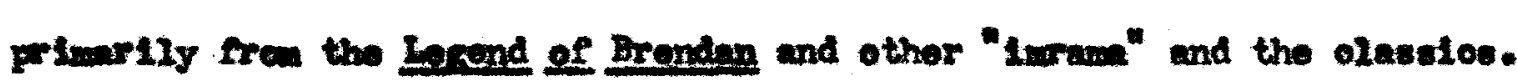
The fest that Brenden is aupposed to hav otartod from this posts sould explain the almilarition of 8 poneor's Ielands and seas to the Irieh ocast. Spmoser doubtless did know somothing of this part of Irelend

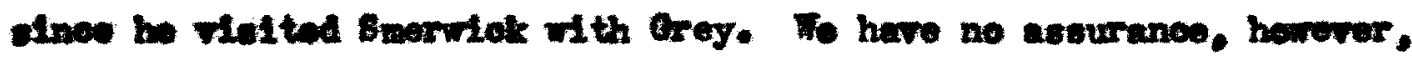
that bo ever wale the veynge up the ocast, and his knowledge wa at bent cooven havd. The faet that the Bower le pleoed in a late rather than in

1 Cr. pe $113-117$

2 P. Honloy, op. oft. $\rightarrow$ Pe 214-117 
the ves wa cwe comothing to 8 penser" intense adniration of the XI1Iarnoy lakse with he haw Asited on this saw expedition, bat this to is sorienthet doubthul. The rividnees of the pletare of the Bewer and of Fhadria's Island, however. 1s porhape twe to the fact thit. though the poet mo draring from Iegendary wowrees, he himedif had seen alpot ofmiler places of exquist to beaty whioh onabled him to gaint atails cominoingly and oenoretely. In ouch passage it is imposotble to separate Ine from Iine, eaying "this is Celties that is eleasical".

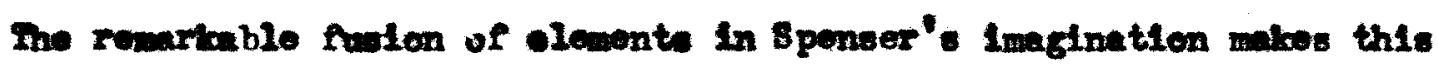
1mposeible. The elgalfieant point is that on of the olemonte wioh was Twed was inth.

- There are wany desoriptions of storms on Ind and sea which are

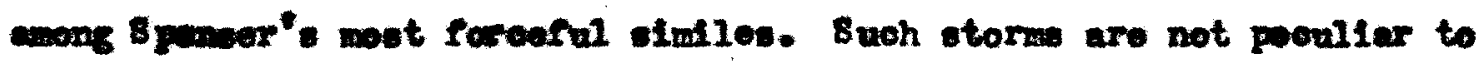
Irolend alome, nor is the wen eromd Ireland different frem any other sea.

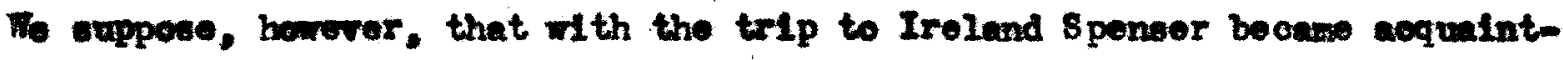

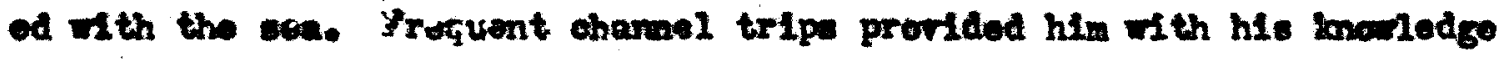
of the I-1oh channol, and the pot was often on or noar the soa at K12-

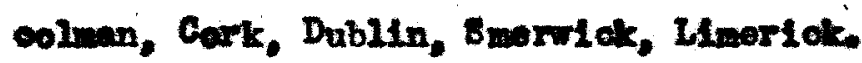

It will be notioed an elove crabination that in the seoond part of the Beerle 9uecne the refleotions of Ireland boowe more definite and mere maverow than in the firet three beoks. The Bag of Allen is the onty Irioh place name wioh oocurs in the first threo bookw in oontrat to the multitus of Irloh rivers, hills and tome montloned in the later booke. It 1s wident that sponser learnod to know and love the oountry more on lenger equalntenes, and his intereat in Irlin mature grom over stronger.

1 cr. Feate 9reone-I, xI, 21-II, V11, 48-II, xi1, 10, 18, 38-III. IT. 1 min. $17,7-i, 1,42,45$ 
During the firet yeare in Irelend, sponor wa wainly in or noar Dublin.

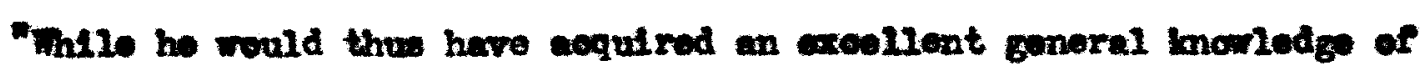
Ireland, he we not in a position to copulro on intionte foulliarity wth eny particular looality. In the eccond porled, however, he wa in uninterrupted occupation of a porwanont how, and onforing a comparative

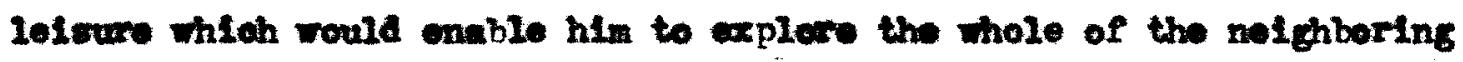

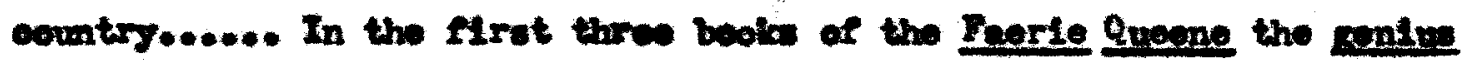
1est is incted apparent, not only in the gonoral ectiling of the tugery. but In wang eppeiflo allwalons but in the veoond portion of the poom, on the other hand. the sovery and the aveodiations of Kilooluan and the wouth of Irelend oolow the wole texture of his woxt and the ocnoludins

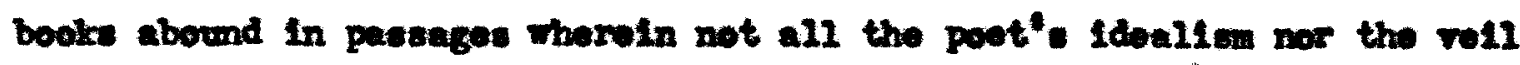

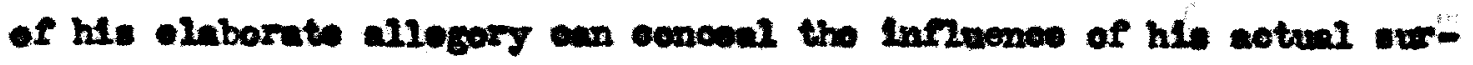
roundinge. both upen the trend of his fanoy and the form in wieh that fang found exprointon."

1 4. C. Rarkinor, op. att. 
Wa

\section{8}

GHPIR 7

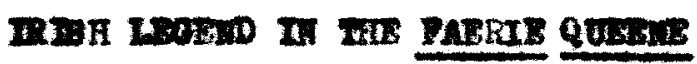




\section{ORIPIRR T}

\section{IRISH LEOEN II TE RAERIE QULEW}

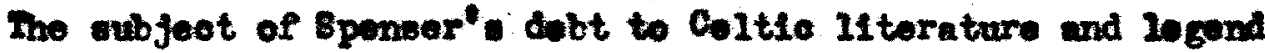

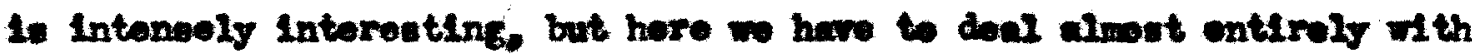
conjecture. In the Ier of the Frecent 8 tate of Irolan. 8 pensor gives oridence of his lnowledge of Irlah history and logond through his study of the Inglidh, Intin and Irish authorlties. Horeover, ooncerning Irtuh

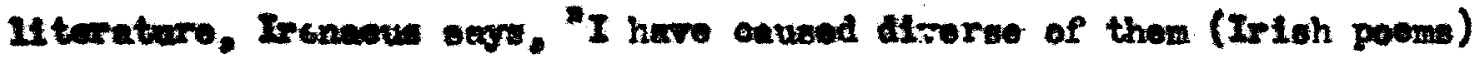

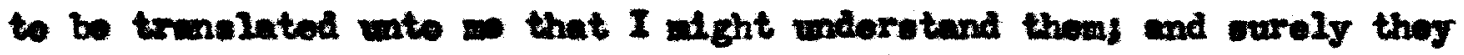
servared of areote wite and goad invontion, but aldied not of the coedly emewontes of Poetryel yot wore they oprinkled with wew protty

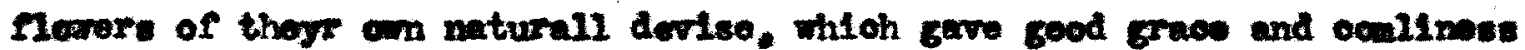
wite then, the which it is greate pittje to see soe abued to the graelng of riokedness and rice, which rould sith good usage serve to beautify

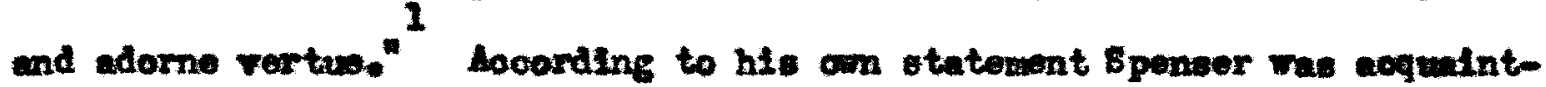
2 al with the lere of Irelend as told by 1 te own Bards and Chronlolers. Whether Bpencer knew these writings in the original or not we

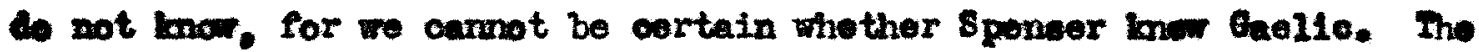
foot that he had tho pown translated woold imply thet ho did not. Fo Inom that he would rever heve dolgned to we the Fteh languago as wany $\mathbf{2}$

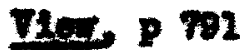
2 1010. P 76 
Anglo-Irioh ald in tholr dally aourorsations. On tho othor hand, it would woen etrange if a man of 8penser's Intollact should live in a oountry for elghteen yoars and moke no attompt to beoome acounintod with the native lengrage, espeolelly at a time when the Ronalseanoe 20ve of loarning had brought that tongue into sowe dogres of popalarity 2

in tho Mnglish court. The Irieh torms ueod in the Vier Impiy a elight monledge of Gabl10, but it is probably as Drapor saye that "speneer" knemedge of linguistios was sedis narrow, expooinlly of Coltio IIncudeties". Sponser's om otatement indioatos that, even if he loner Boollo, he did not rol himelf accurate onough to malerntand the roal woaning of the work. The Important faot, arter all, Is that he

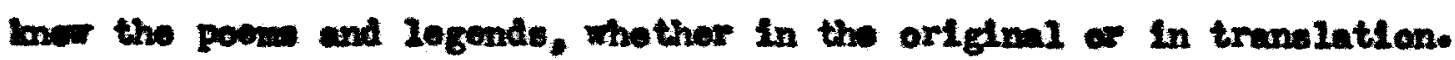
Wh do not know el ther, wo trensiatod the poome for 8ponser. It has been wresested that it wa Roohs's berd, Fedby, who Inatruoted Spenser in the lare of Ireland. Honloy belleves that the Tolg 01mve wontioned in the recorts of sponser's IItigation of th Rook is this sems radiyy. In that onse, wo have oridence of the poet's aegunintence With the bard. Other opportunities to learn the legende of the Iand

1 In, p 78

2 P. Honley, op. alt. P 200

8

J. T. Draper. "Sponeor"s Inguistion in the Prosent state of Iroland" Hodern Pillelor-vrI-1010-pe in-196

4

H. 8. V. Jenos, Bpener Endbock-p 306

5

P. Honiog, op. oft. P 68-note 47 
Wore mustons. Spenser's ecqualntance with the Barl of arwond, Whose castlo at IIlkenny he colobrates as the Irikh howe of the kuses, mat have profided him it wany opportunities to gathar Irlah lore from burds and winstrels. Horeover, Trom the earliest days. Ireland hes boen a land of hero and feiry tales, and hardy a brook or hill is Ithout Its history. Iravelling through the land as he did, 8 penow oould not have falled to hear of the gode and salnts and fairy folk the onee popled win. The references to the Pouke and the hobgoblin: about Mloolwan in the Botthalamion show a knowedge of the fork logende of his own alstriot at loset.

\section{Bromax" strange mothod of mingling rdely diversteled}

lowente in his work makes a considoration of his sourees very diffiealt. -Distinotions of alessteal and romantic, ancient and modern, encred and profane, have no moening for him. Where others distinguigh, he is onit consolove of the mity of all that has arrested the hwan inaginition. The colectio wothod is porowed alike in the main waving of his plot,

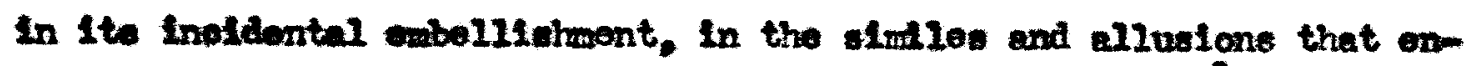
rieh his otyle and drive howe his inaginative oonoeption." Thus. In the consideration of the inflwence of Irleh logend on 8 penser. we to not noan to Imply that the Celtic souroes are the only anos for thees cortaln paseagos, nor indoed, In many cases, the noct important onew. Our parpose is to show that they form an integral part of that back growd Irem wieh sponser wove his Fatry land and areatod his "Inights ar the Mydahot"

One of the wowt outateanding parailele to coltlo legend in the

\section{1}

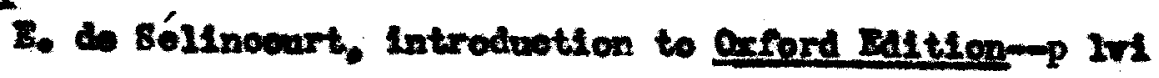




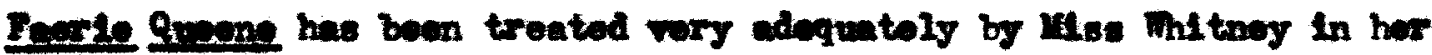
comparieon of the journey of Guyen to the Bower of Blies with the old 1

logend of $8 t$. Brondan. St. Brendan was an Irleh wonk of the sixth oentrary (404-6T) who was know as one of the Mrelve saints of Brin, and who foundod the monastery of Clonfert. It made tro vosages in searah of "the mysteriow land far from mank ken" whioh he finally reached on the weoond fournty. His experienove ware celobrated in the Coltio Irre Brendaln wioh we later widely knom in the wore elab-

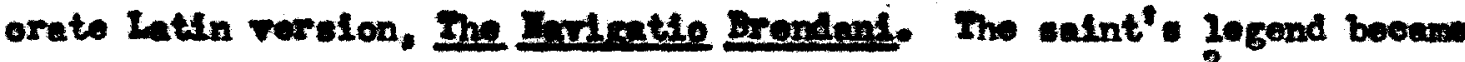
so poppiar that it was transiated into Fronoh and Bnglleh. It soems probable that 8 penser wed the Anglish prose rersion knom as the Glden Lerend.

This would wom, probably, an indirvet influonos from Iroland, but the ctory itoelf was ultimately Geltio, and even in the modiovil

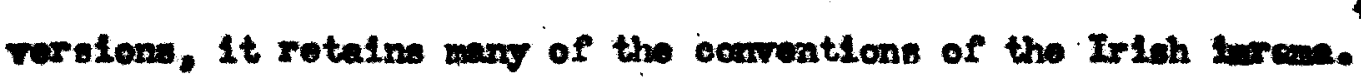
The conoral charaoter of the two rogeges is inilar. Brendan and the Pulmer are parallel throughout, in that they marn agalnat dangers, diupel maraudere and koep the beat in a stralght course ternard the leland

1 Lot. Whitwey. "Bpenver's Ose of the Lterature of Travel in the

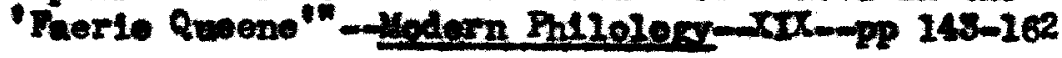

2 Cr. Dowlepadie Anerionna-Brendan

8 Lete Initroy, op. oft.

4

The inew in a cea vogage tale in whioh a hore acoompanied

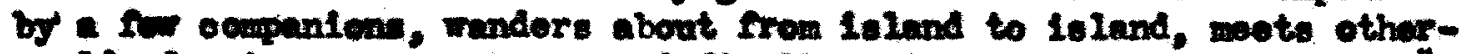

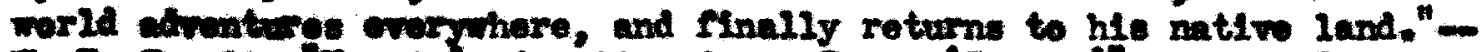

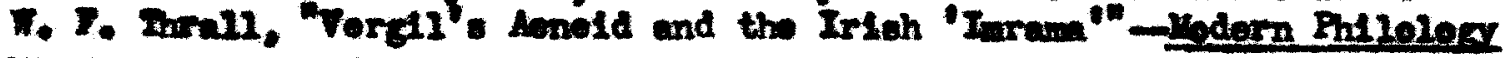
$x+1927-266-92$ 


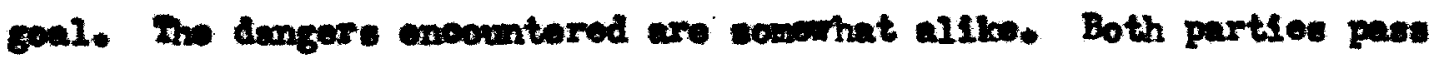
wailoring 1010s, but fayen hurries by, wile Brenden and his wen stop and atwobark, enly to Iearn that the "Island" is a mentrove fish. Brenden's ship is followed by a malo "catbrige is mooho water out of his wouth into the Aype that they wupesed to have

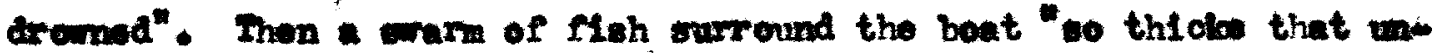

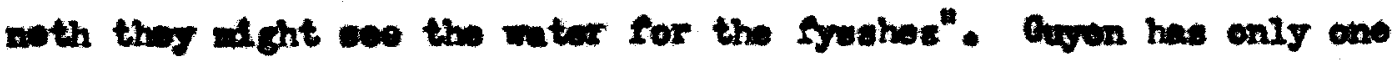

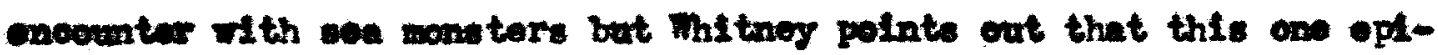
wede Inoorporates the features of both of these in the iegend.

"Buclein thoy see fron aldat of all the latine.

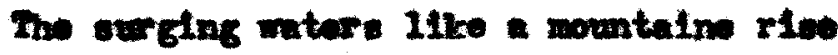
And the groat sea purt up with groud divdain Te erell abow the nearure of his oulse. is threatning to dovoure all that his porre aloptes."

$$
(I x, x 12,21)
$$

Then followod the waltitude of fieh, monaters in this case, that orond

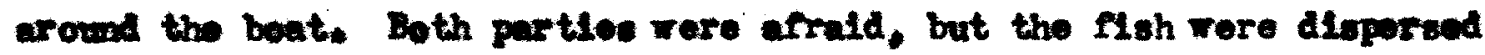
In the case whon the saint sald ans, In the othor won the Palmar wete the vaters with his "vortuove staffe".

4. Brendan neared his goal, a "dorke mytt" enveloped the ahip and the won worv badly Irightonod. So, on Guyon's voyage

Buidointy a groseo fog oreraprod

Wth his dull vepour all that desert has

Lad hoarens ohoarefull face uneloped

That all thing one, and an nothing was

ad this groet wivore com "d one confused mas."

$$
(x, 211,34)
$$


And thoy "roarod to wando in that wasterul wist. Inis wist is a

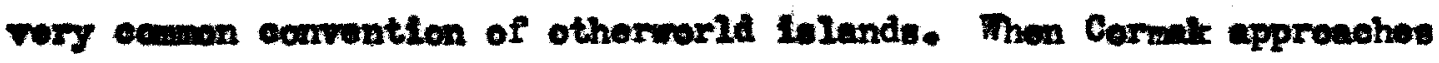

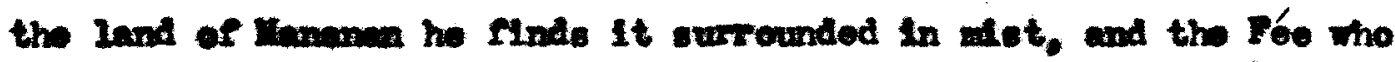

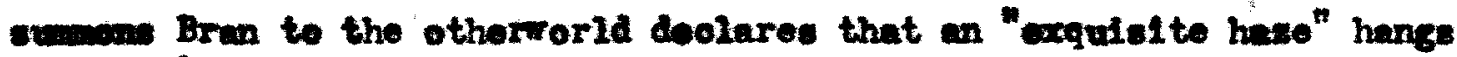
1

over 1 t.

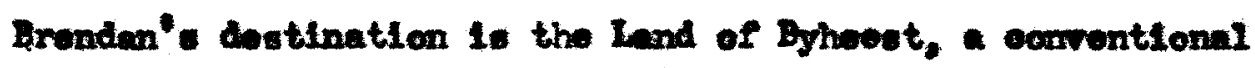
otherworid, and the Bower af Bifse has woh in oownon if th $1 t_{\text {, though }}$ Eponeer has alapted the paratize inte a lowiy Iand of temptation to eave the parpoes of his allegary, and has made the Roo a wloked en-

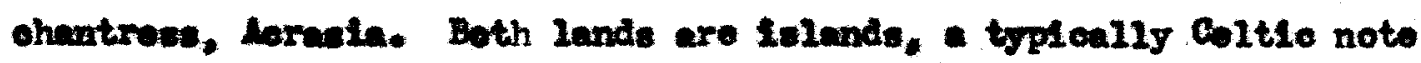
In contraet to the mocutain aod by raves, probably of Oriental origin.

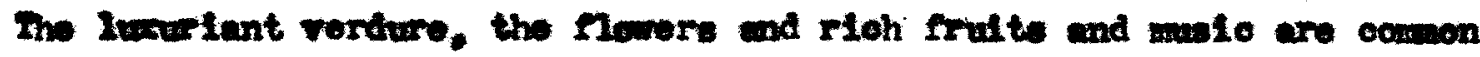
to both inlends.

Othor foatures of the Bowr of Bline are fowa in other Celtie acowents of the Fatry Otherworld. The wall of the Bower was thin and

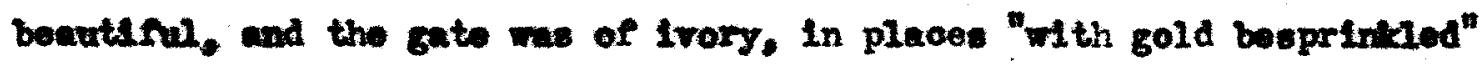

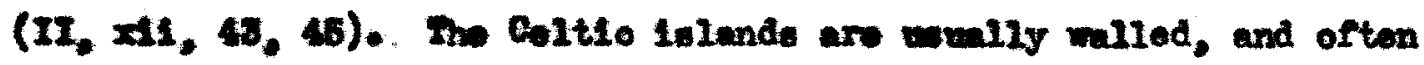

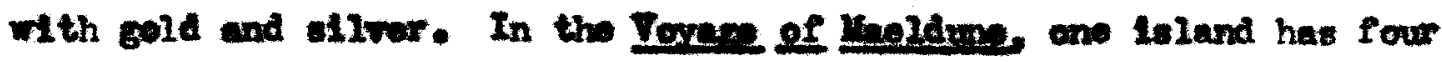

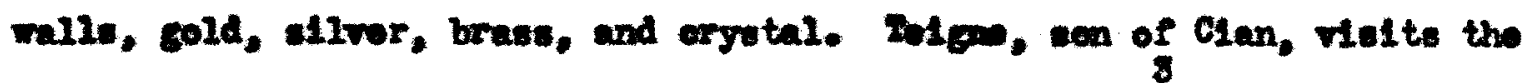
Ints Fatwos whioh has both silver and golden pallsades.

In the Boreh, Gron and the Rulmer ser

*an cubracing rino

1

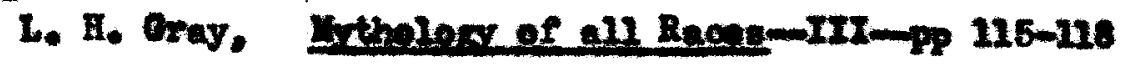

2 L. Whituog, op. at.

3

L. Whiturg, ep. ofto 
Whose bowohes hanglng dewne, evered to entto

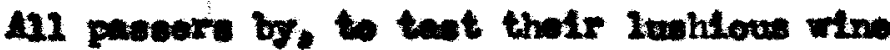

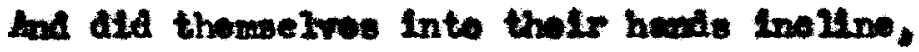

1. Preely offoring to be gathered!

Bow doope empurplad as the Hyolnt.

Bew the Dubine, laughing wowty rod.

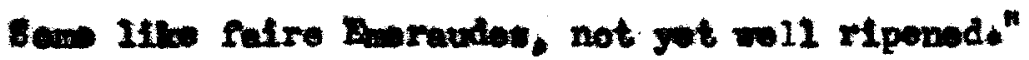

$$
\text { (xt, } x, \ldots)
$$

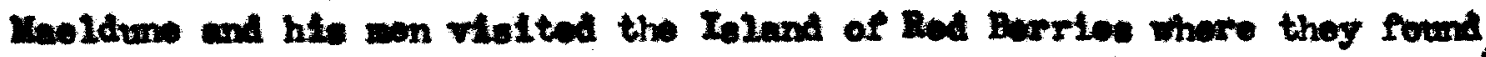

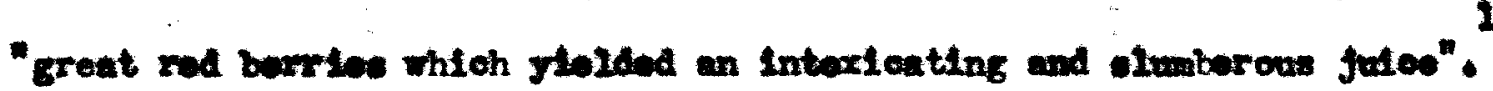

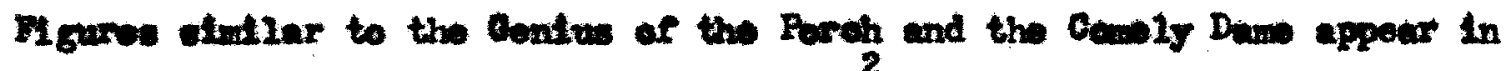
the prephoes to Com the Enared Fighter.

the wole landeape of the Tale of the Liting it in the Bowror

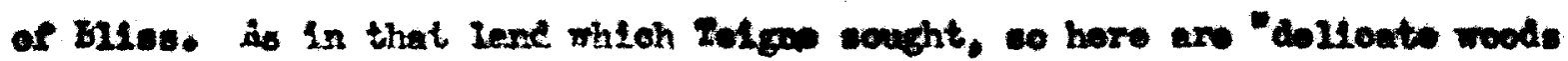

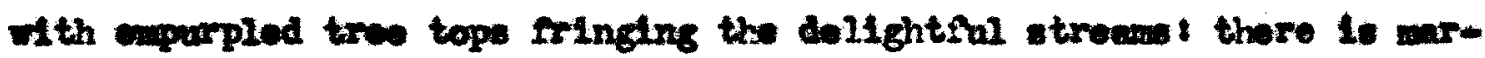

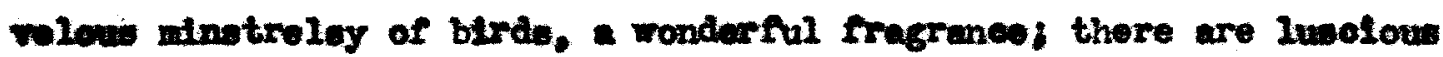

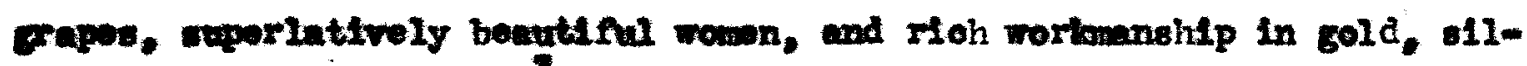
vor and prodoris jomels."

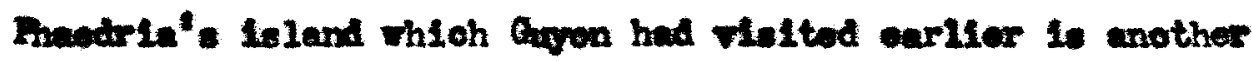
ereaple of the sam Irish othomor1d. "Uagh We11" "Ielo of the HVing".

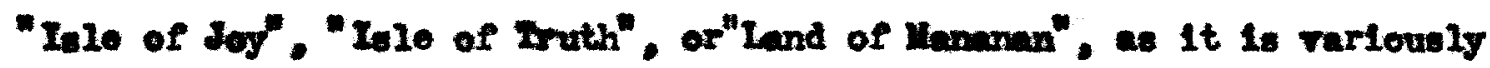
anlied. The benty of the plece, the fracranee distilled from the flovers,

1

7. Fo Rollevton, Irthe end Lerends of the Celtso Race

2

P. Henlog, op. olt. ip $117-118$

3

I. Whitwes, ope oft. 
the bird sange, the shady dale and grasey plain, -all rooall the Land of the living.

Phadria horsele is a fit inhabitant for the Celtic otherwarid. $8 \mathrm{n}$ is essentialiy the fée who fulls in 20 ve with a mortal and

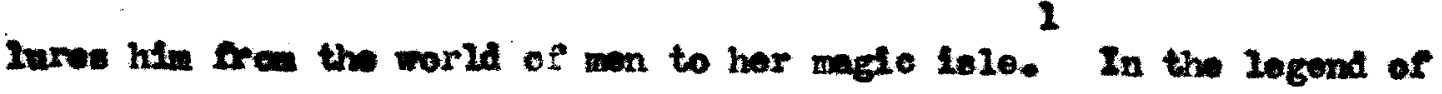
Grnis of the Golten Ifix. Iady oomes to Comia to toll hin of her falr abode,
A land of youth, a land of rost
A Innd from sorrom freo
It I1ee far off in the golden wost
on the vorge of the ature sen."

Lile Fhoodria, tho Indy had a megic boat "a orift canoe of arystal

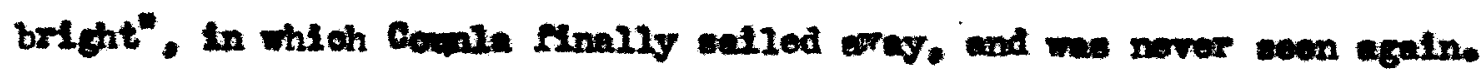
Phoodrte sinaller onip

Mare orift than arallo wheres the liqudd slde Fithouton care or Plote it to guide Or winged campas with the wind to file Only oho turnod a pin, and by and by, It out arey upen the ylolding weve Wo oared the her couree for to applys For It was taught tho way, which she would have And both from rooke and Nats 1teelfo oould wisely

$$
\text { ome." (II, } 1,8)
$$

2

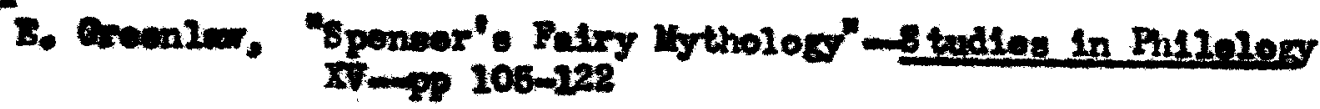

2

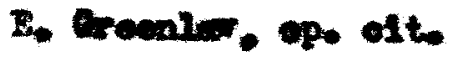




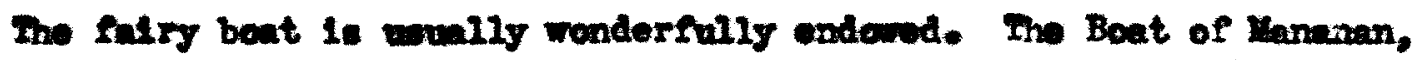

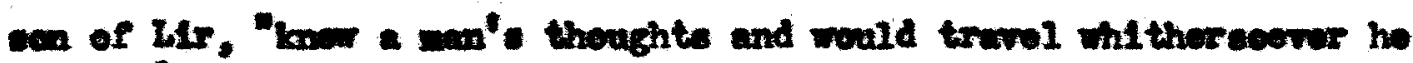
mond". 1

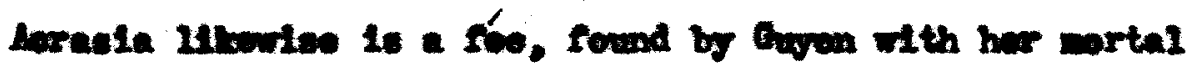
10wer. Greonio has pointed oat other wees of the for wotif in the

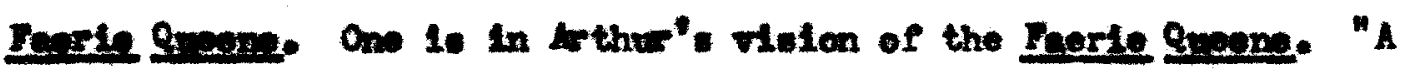

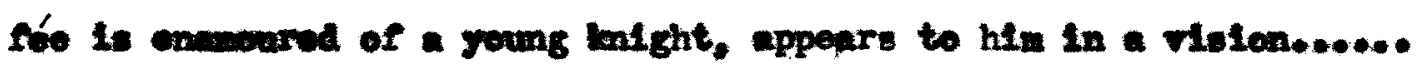

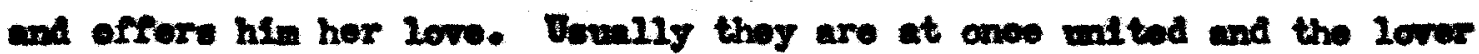

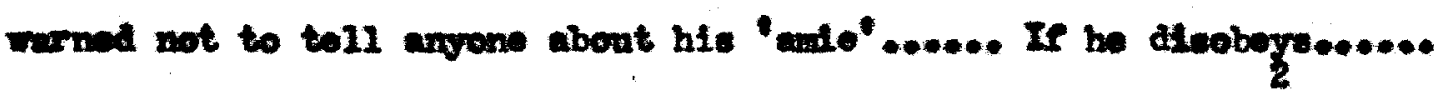

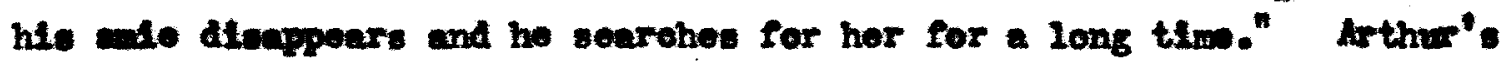

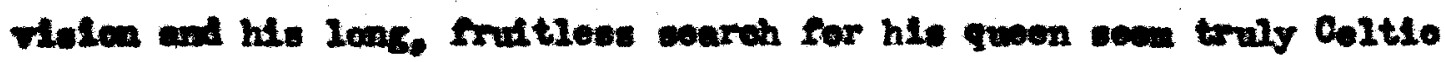
In tan and treationte.

In the Irith legend, to yeid to the fó is ruther desirable then otherrise. The tale of Collon and his roaletanos egainet the charva of Gign ab Fîd is one of the row which gives any hint that the good wan it not ono wo yields to the fulry folk. sponser ven the

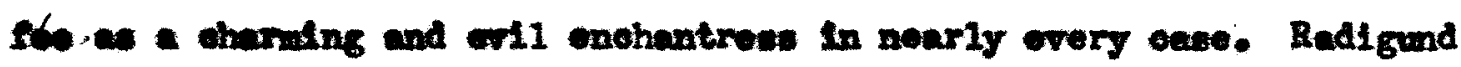

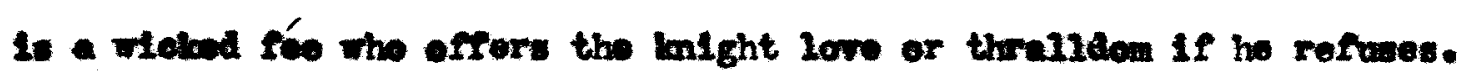
In enother garallel wioh Eromien wontion there is no tamp

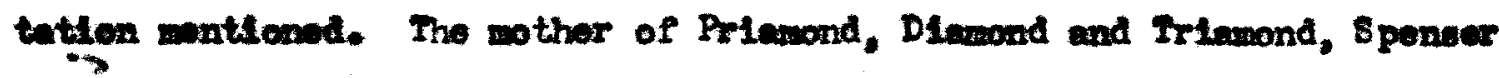
etetes definitely, wa a Py. Loreover

$$
\text { "we had the old11 }
$$

1

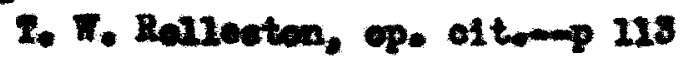

2 E. Broontar. op alt.

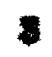
D. Eroonion, op. at. 
of secret-thinge and all the porres of ratare

Which she by art could nee unto her will

And to hor sorvice bind each living oreature

Mrough seoret wderstanding of their feature."

Her beauty. her oll11 in leocir craft, hor goodly otaturo aro all in beoping wth the comventlonal foo. Her mamer of living in the foreste Insteal of on on Island differentiates hor from the other fóes wo have considared. but sive is atill of the seme race. 8 he is of the siahe folk. "the good poople" who tho Irlsh peasants deolare st111 Iive in

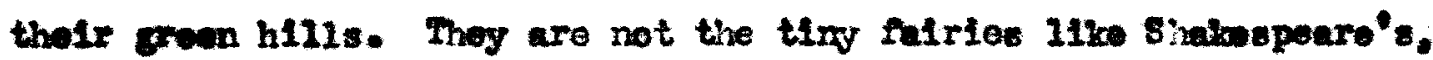
but belng of majestio stature, the people of the goddese Dane, called Tuath $D_{0}$ Daman, who held Ireland for many years. Finally they wore

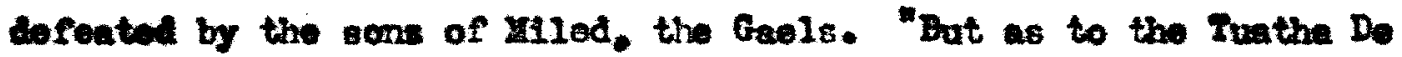
Danuen. after they were beatan, they weuld not go under the sway of the sons of uliled but they wont any by themeelves. And beoune Kananan, con of Lir. waterstood all enchantmente. thoy left it to hin to find

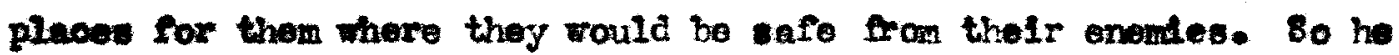
whose out the nost beaudiful hils and vallogr of Ireland for then to

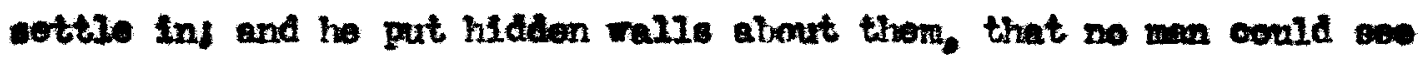
through but they thomelves could seo through them and pase through

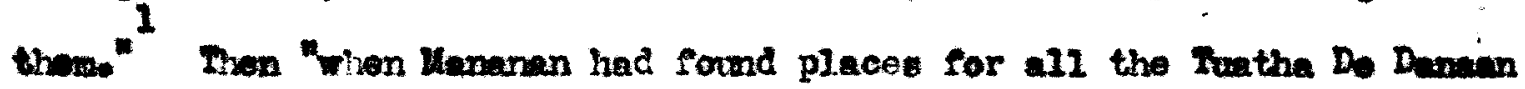
t 11ve in, he himelr left Ireland and went to droll in a covatry bayond the na." - the Ind of the Living. Fro this land case the fore whe 1

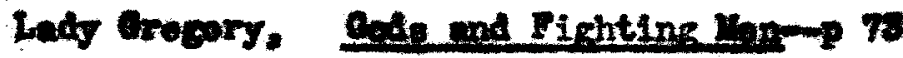
2 Tbld, 100 


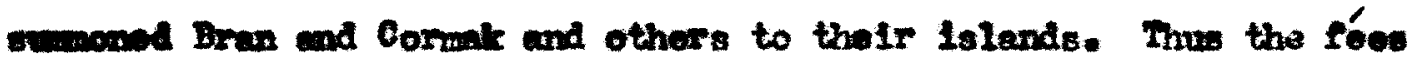
are all eriginally Iuthe Do Danaan-beth those of the aglo hills and thowe of the nafle lales.

ereonier eftes nonts who think that the wother of the throe werriere wy have been suggested by the story of a partionier fue af

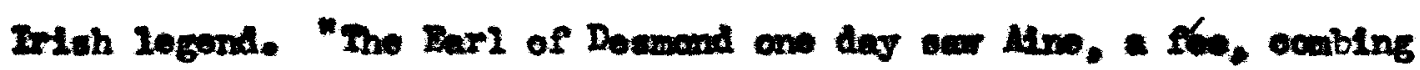
hor hatr on the bank of the river Carwog noar Lough Axr. Favelnated by har beauty, he fainod control of her by eatehing hold of her cloak. Fros this unten was born the enohented horo corote." the parailel in Ituation and satting seome convinatng.

The oplade in whioh Calldor watohes the Oraoed dancing a-

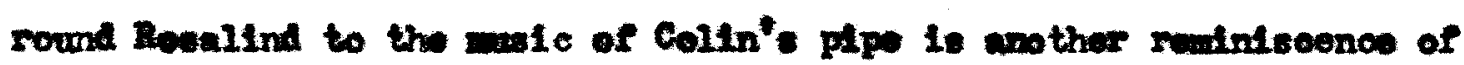
the sidhe logende. All the detali, whe falry hill. for of frow

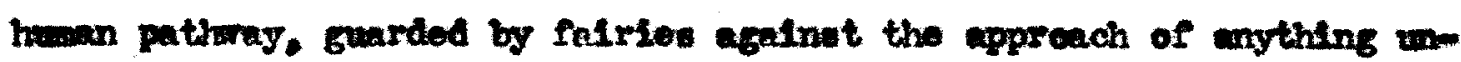
aloant the fulry maste hourd frow a great aletences the hundred danoers, the feo horeale in the center of the group; the disappearance at the apreach of a nortel not inftiated into the myoteries of the fairy folloal these are ceswonpleces in folk tradition."

Thure are nary 10 se astinct reflections of logendery lore in the Feerie Queon whioh are still worthy of note. For inetance, the now "Bna" is that of a fuiry quoen of Irelond, but it is not cortain that sponar got his nome frow this falry. Britowart in hor armor is woh 11: the Irloh war goddese Hache Fith hor rod gold halr gathered

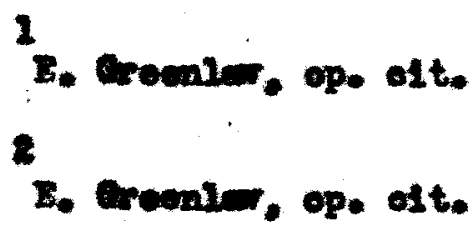




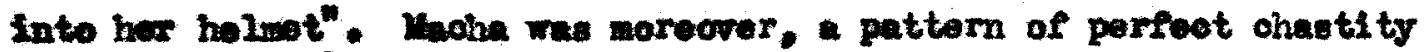
1

14k Eritemart. The reacublence of the hage, Dary and Dotraction to the three tentible daughters of a chlef of the futhe has bees potated out.

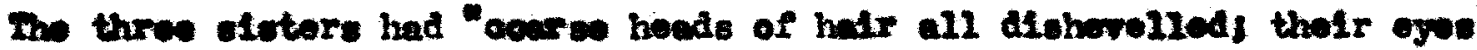
Thover and rodly bleareds their three nouthe black and doformed, and in

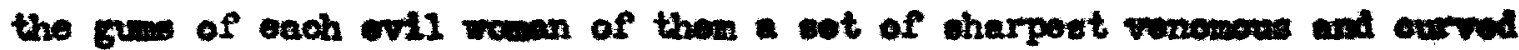

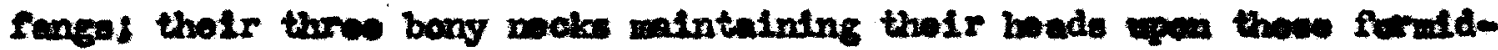

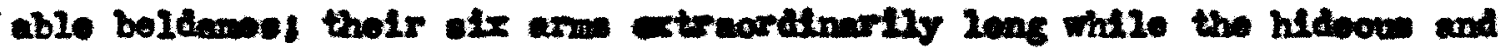

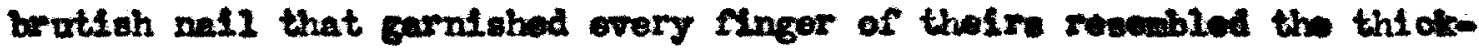

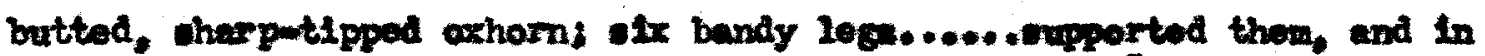

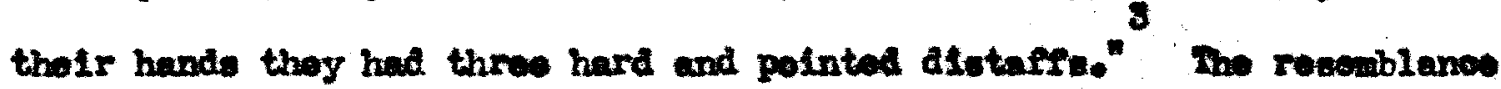

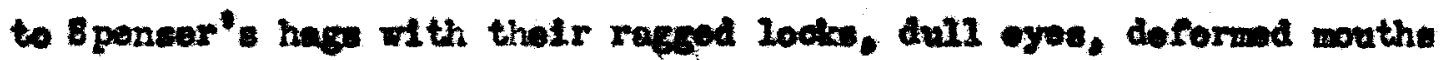

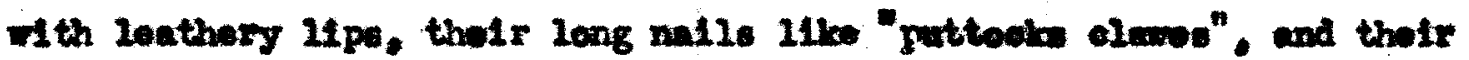
altaffe. Is cartalniy markod.

Boniey romarias the sindiarity of Minda" fight at the ford to the Nght of Yordiad at the ford with Cuohvialn, bat the atudiarity onde wth the swot that the sotting is at the ford. and that Fordiad is forsed to Aght by a threat of alegrace, Frobably a Iitile like Despotto or Doopto.

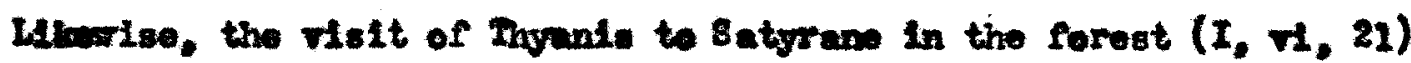

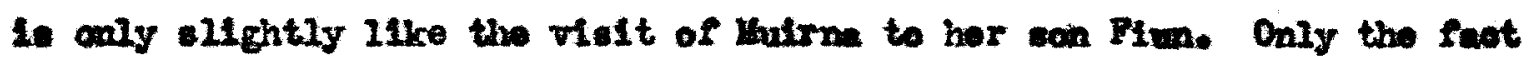

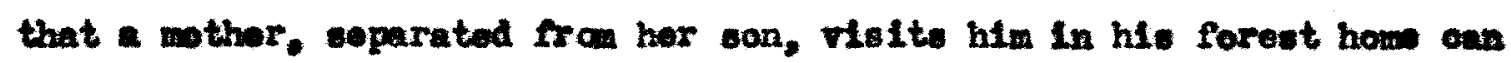
expert the prallel mioh Henley montions.

1 P. Bealey, Op, oft. $p 213$

2 Ib1d, p. 124

3 


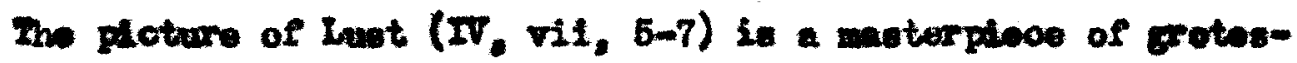
quarlo werosting sose mad drean or a moter from fulry land. Thoufh ho derives frow other sources aleo, he owes soming thing the olasele

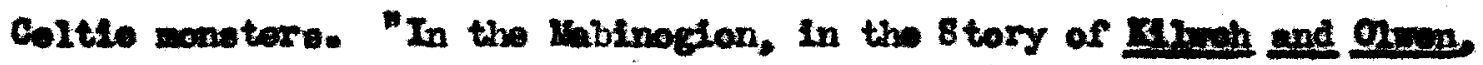
Gnows. son of Grosted had lipe so large that he oould drop on bolow his walete, and oover his hend with the other." ${ }^{2}$

These resemblaness serve to show that, although the reflootion 1s comotivo vague and the parallel unoertain, spenser abeorbed waoh of the atmosphere and fooling of the lore of Erin. Coltsc gods and falries appear In his Enerie 9veene edaptod to the alle;ory, but still preservIng woh of the charwoteriatic foutures of the orlefinale.

1

L. Whituog, op, oft. 
CLAPTER VI

conoterse. 


\section{CTAPTR VI}

\section{Concuston}

The procedine chaptors hove hoon an attompt to sher that Irolend exoroleed a very definfte Influence on spenser. and to point out the speciflc ovldences of that influance in the Paerle Sueene. These oridences here been considerec under four hoads. Tf first diucuseed the politioal pollcy of subjeotion thich sponser adrocates in hes deronse of Lord Grey and sought to prove thet this policy was the natural rosult of the poet's intinate connoction with the gorermont as an offletal of the orom. Considered in the light of the provilent governmental pollcies of spenser"s age, the situntion of Ireland, and the necessity for imedlate and decleive action, the poet's positson 1s underatandable. His diagnosis shors keen judgnent and thorough atrudy of the frote. If he was a chemption of Ingland's dantizion before ho oame to Irolend, his exporienoos Intonsifled hls opintons and gure then body, malling his corritotion so strong that the last books of the Peerle gueane, es well as is prose trects, ring ath hls ory for doe efetwe eotion to insure Ireland for the oram.

In the socund place, we considered the affeot of Spenser". expertionoes In Ireland on the genoral oonooption of the Peerle Qveene and wontioned wany of the concrate detelils Arun Prow the Irloh wars wioh elve color end vitality to the narrative. Mruo Bnglishmen that he wa, sponwor ene in Ireland a conteat betroon good and ovil not mItice that which be mas reocunting in his pom. So it happens very 


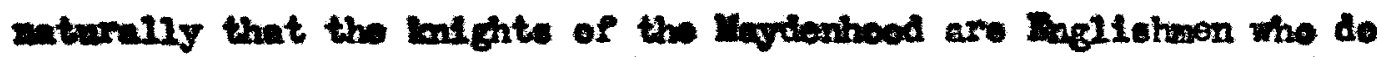
battlo ageinst the powers of orll, mny of then bear a morked rom

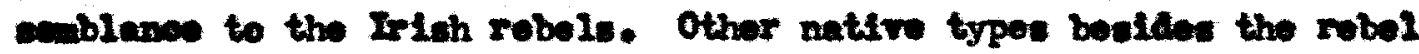
coldiere are aleo distingulehable. To belleve that 8penaor'. vurled coporionowe in marutorn Irelend provided hin with wealth of graphle dotalls which give body and Vividnese to his talee-me eort of reallem whioh bo could hardis have attalnod in Fhgland.

Inirdily, wo have shown hew wooh of the topography of Ireland

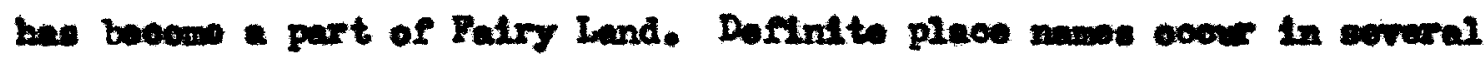

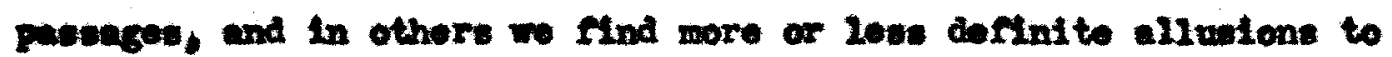
Irteh soenery, partiouluriy that which the poet know bout in Munstax.

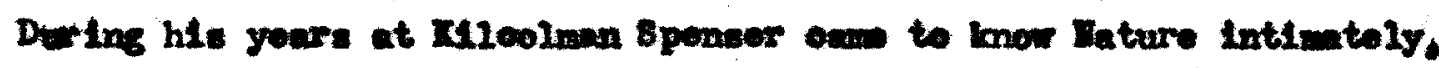
and not worely through the spotades of litorary convontion. He

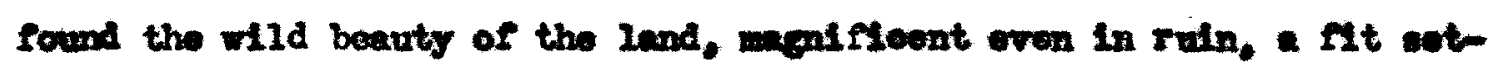

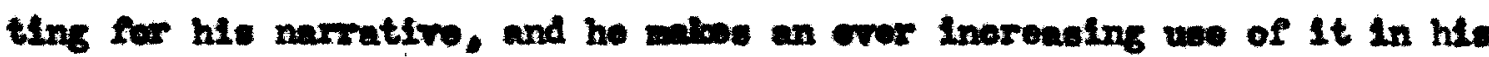
coseriptions of Moriand's realm. Thus, another bit of reallom to be found in spenter"s fanolful werid way be attributad to the Influonoe of Ireland.

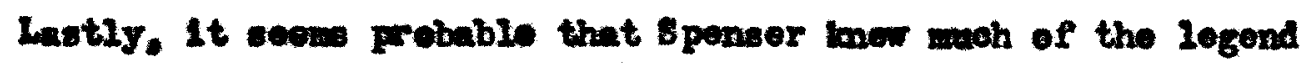
and hlatory of Iroland, and cortaln passages in the Procle Qveen have a doolend Celtio note. Poos and wenters resemblo wows of those belnge who poople the legendary Ireland, and tholr anglo drollinge and their

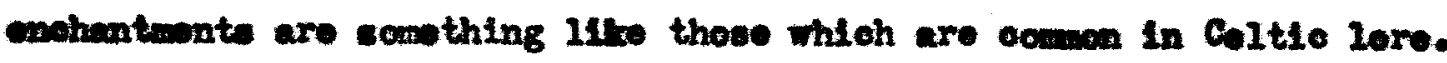

It would have beon otrange Indeed if the reerle Qveen bore no

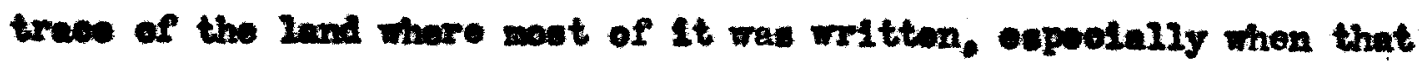

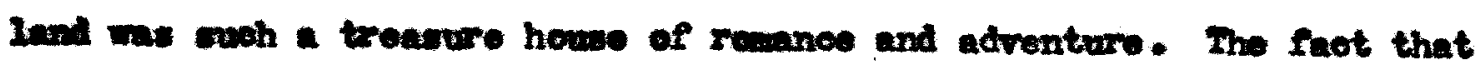

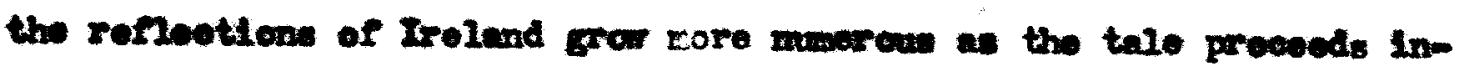


80.

dloate a graing interest in the cointry. Ao sponser boows better acqualnted with it, he foll wore and more under its oharm, and oo

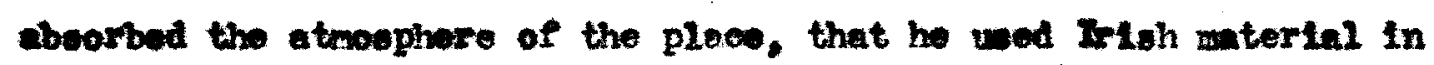

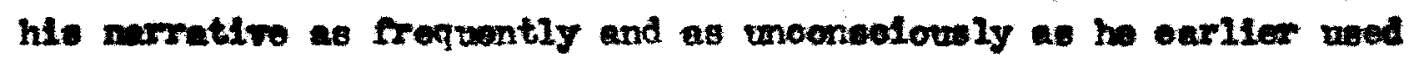

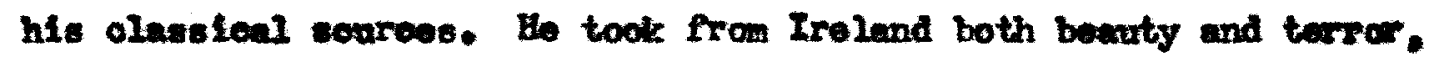
both legend and $11 \mathrm{fo}$, both the real world of wen, and the fantastle land of god and falries. Thu far rolghties is completely jutifled in alling him "the poot of Ireland", for Ireland, wore than Baglent, is reflooted in his tale. But we must not forgot, for the poot nowor ald,

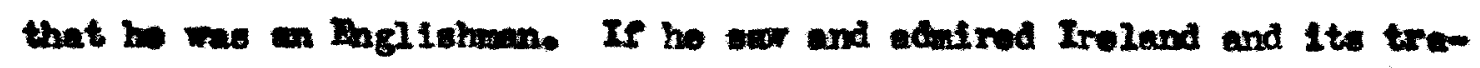
dtions, he nover beows on Irlahman in eny eonse of the word. HIe polnt of Fler we consletentiy Bnglish, and his droem was of an Inglioh Troland wieh he hoped would some day be realised.

2

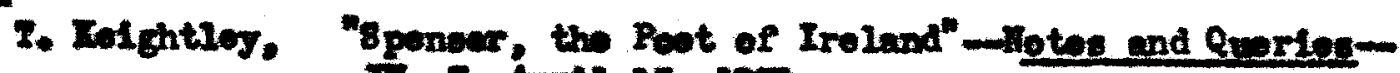

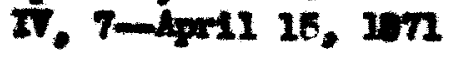


Entogaril 


\section{Buaroanditi}

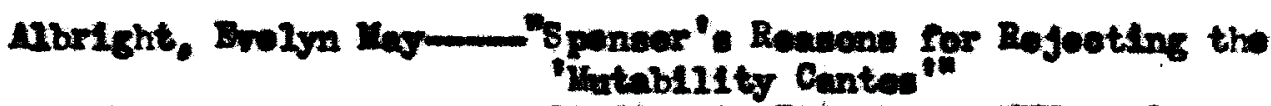

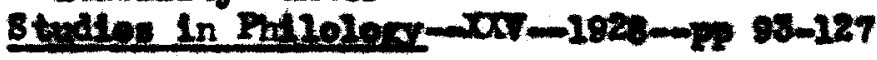

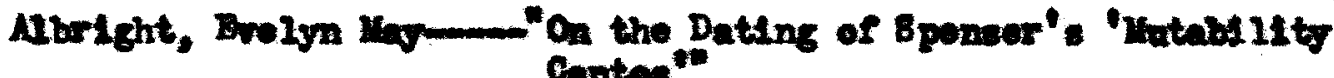
Cantece"

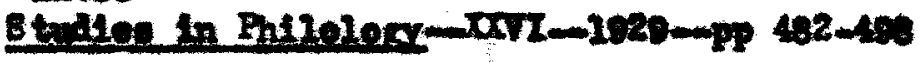

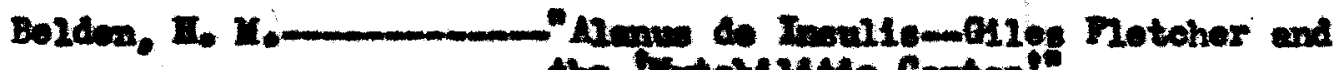

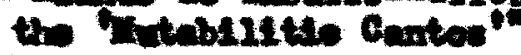

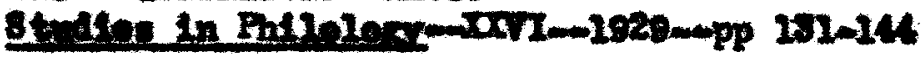

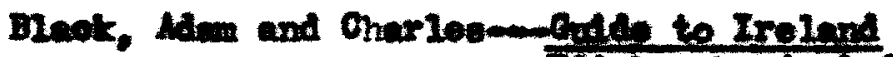

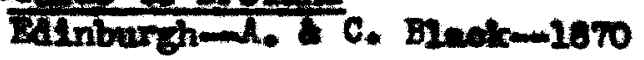

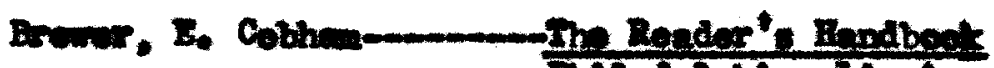

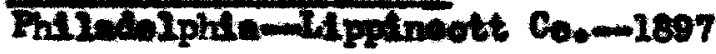

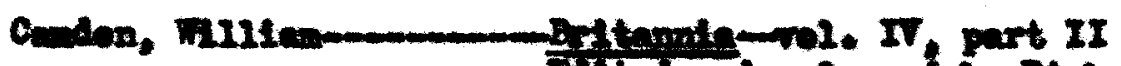

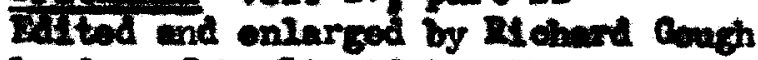

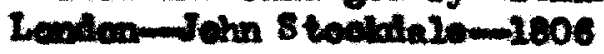

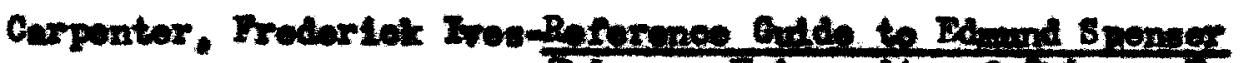
Ciloagomoniveraity of Cheare lroes-29es

Gerponter. Frodertak Irea- Eponser in Irolena"

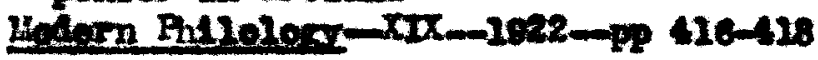

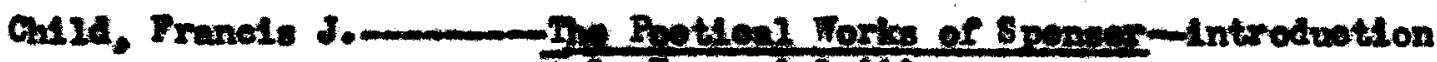
701. I-PR I-1XII

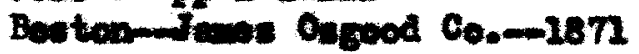

Chureh, $\mathbf{R}, \bar{n}$ $8 \operatorname{sen}$

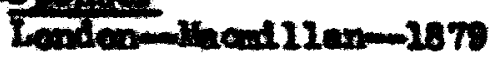

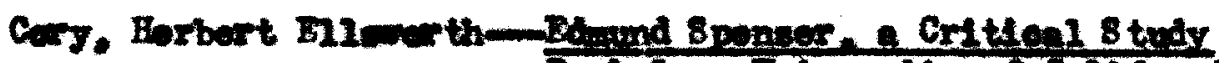

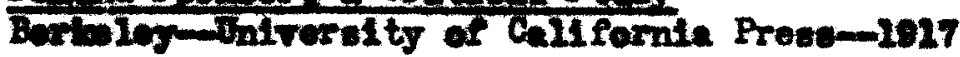

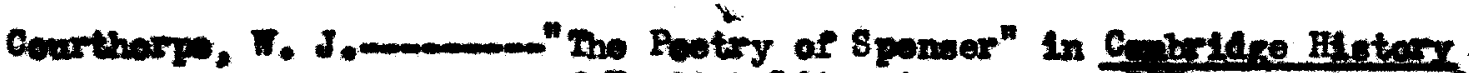

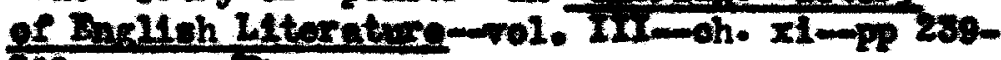
281

Iow York-Putoom-211

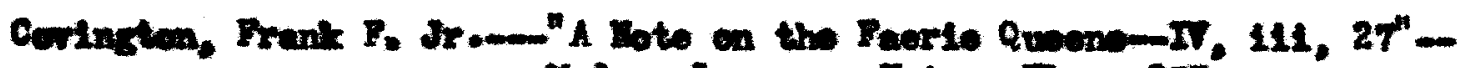

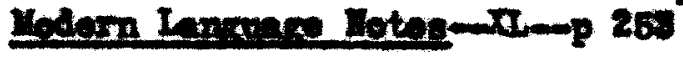

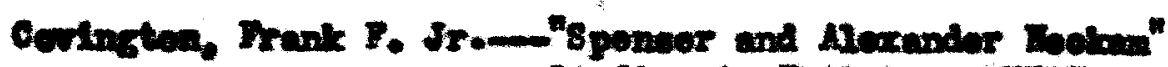

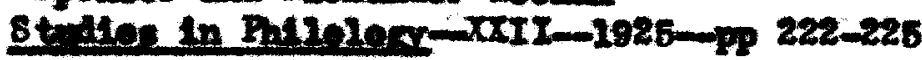




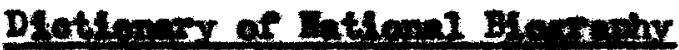

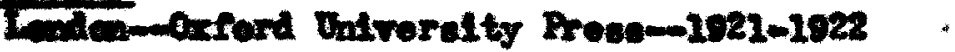

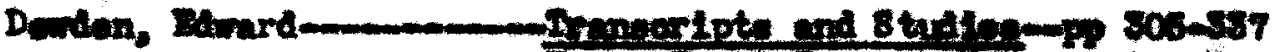

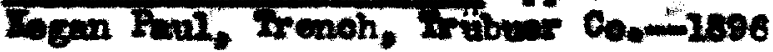

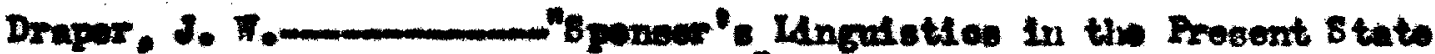
of Treland

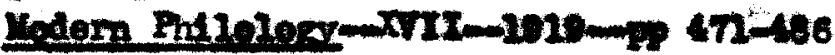

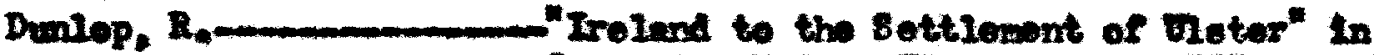

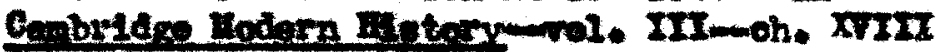

timbriage Batverelty Tress-isos

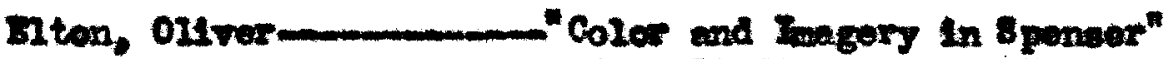

Hodern 8tadies - $67-7$

Bumerd Arnolo -1007

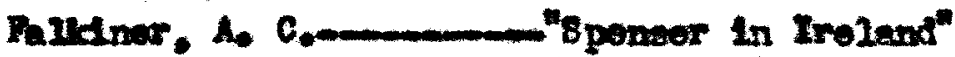

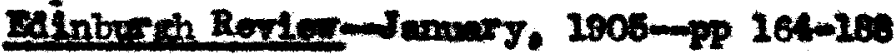

Ftagervid, Thewes F. H.m-Ireland and Rer Peoplemrol. I

Ohloage- Itsgerald Bost Co,-1010

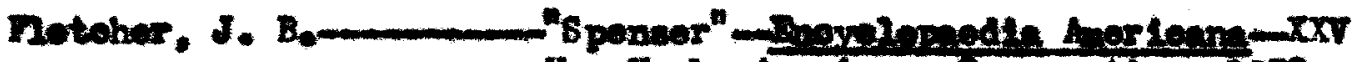

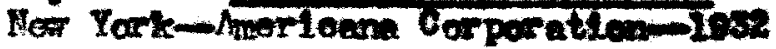

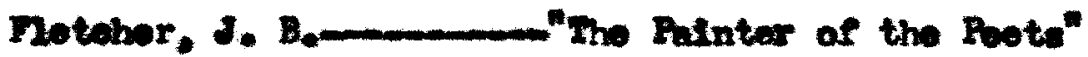

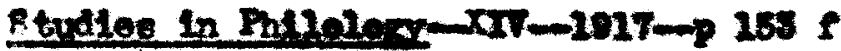

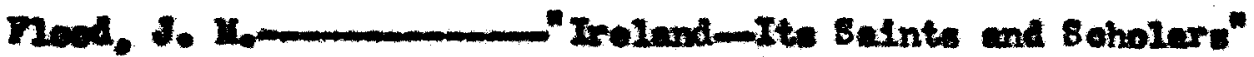

Ior Toxt-P. I. Fowndy-2018

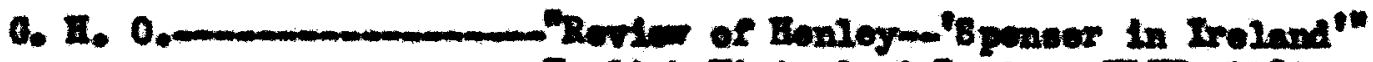

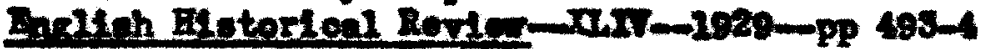

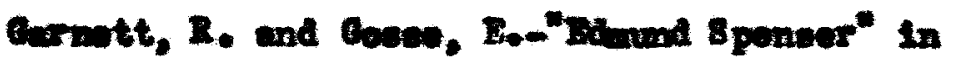

Aprich Lteratar man IIntrated Beoord

Inmoh. It

Dow Toxiz-diacallian-1026

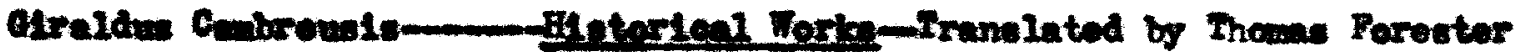
Lenden-1. 6. Bam-1068

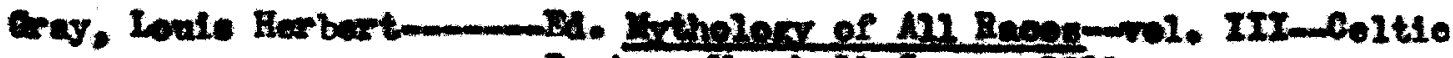
Bonton-Tiardill Javen-1020

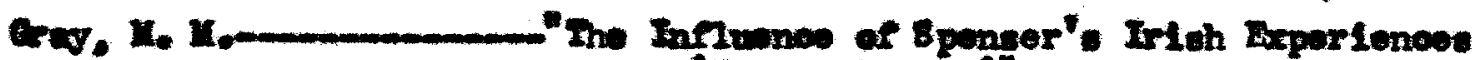
a the "Peorle Quown"

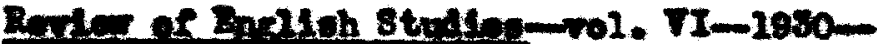
Pex $x$ 


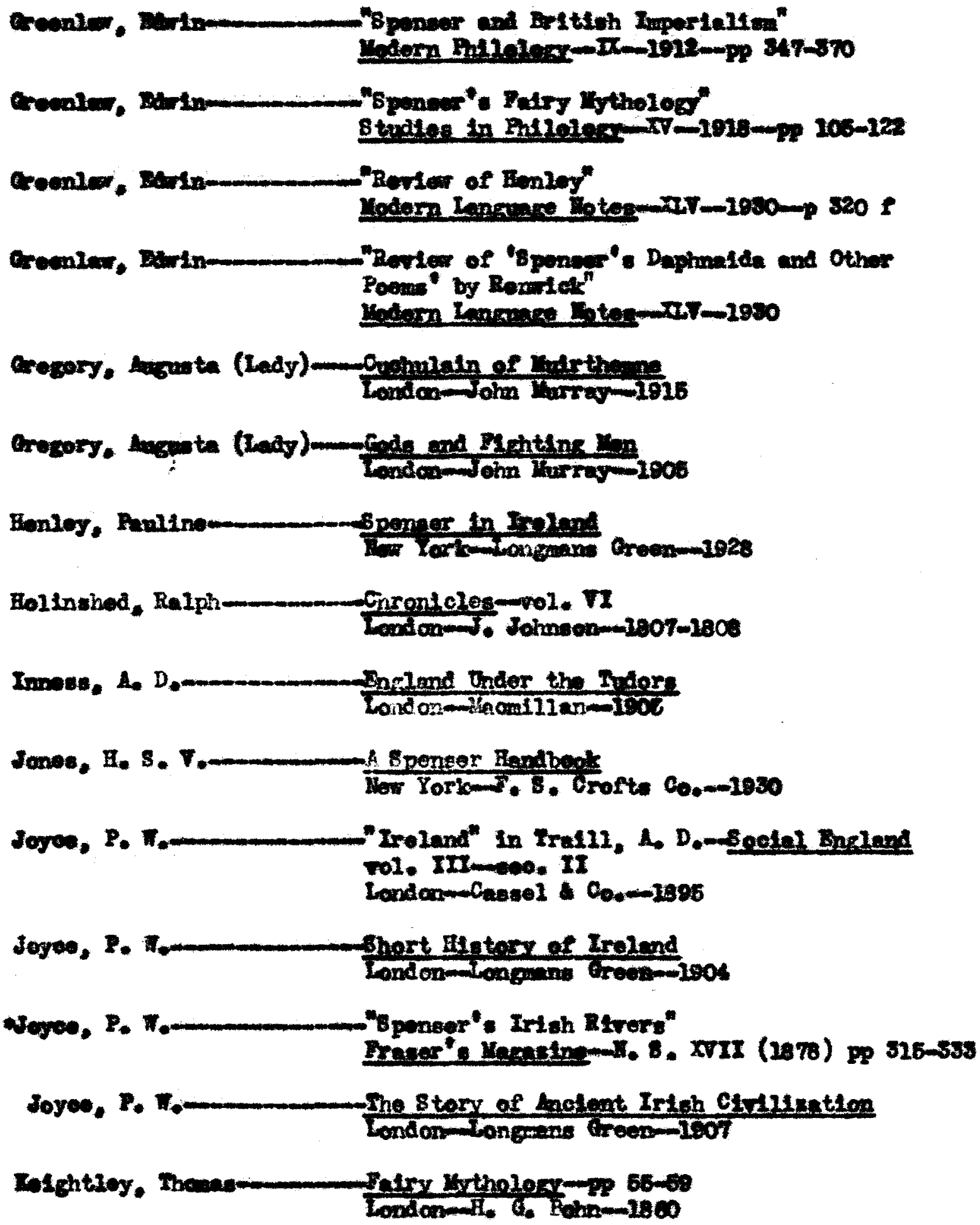

Hat andiablo. 


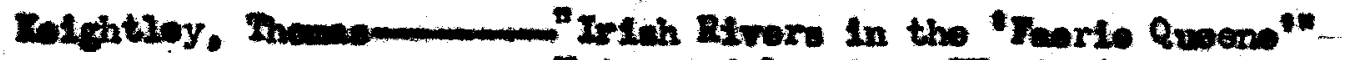

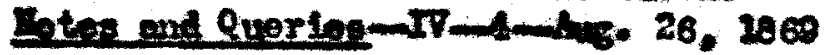

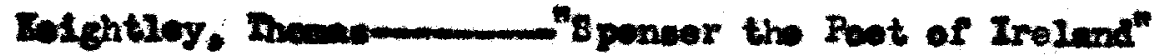

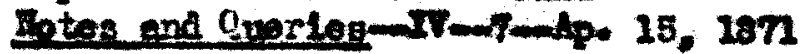

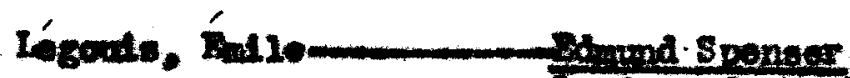

Eadionem. $\mathrm{K}_{6}$ Bent-2926

Dow Toring.: Fo: Dateon

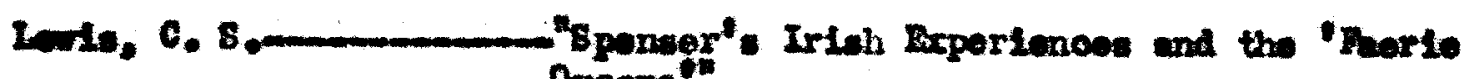
Quoone

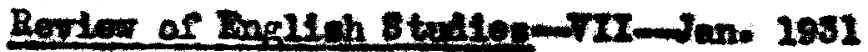
it 80.95

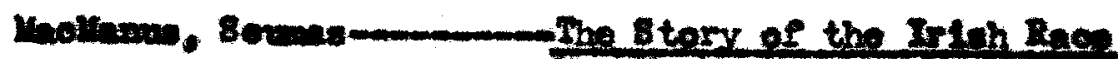

For York-Irish Fublehing Oodm-leat

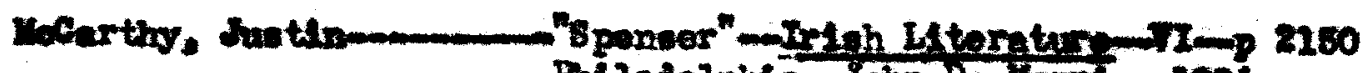

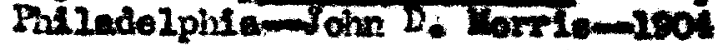

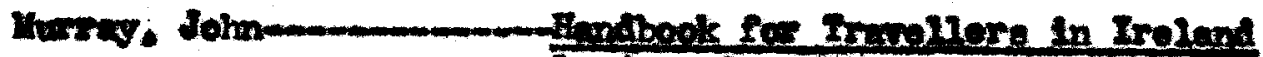
London-Soln Eurraym-1872

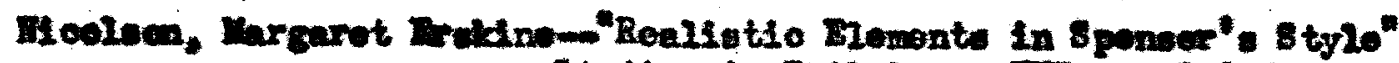

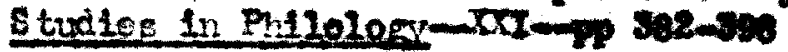

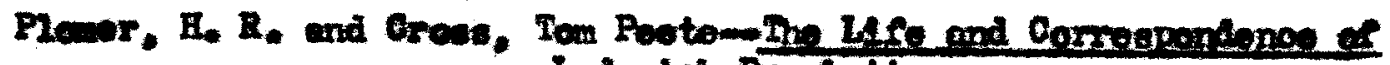
Lodaricle Brapert Ohiongomintvereity of Chioage Prosemilez7 -

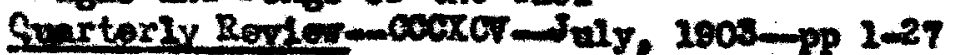

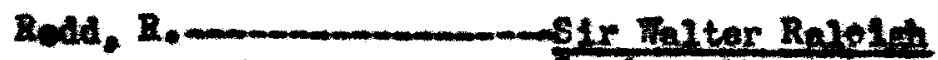

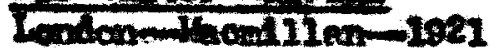

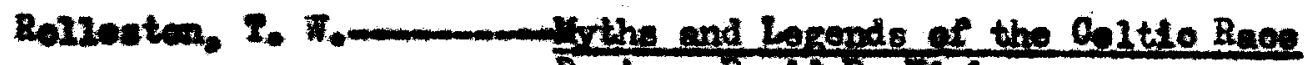
Boton-mavia D. IfTersen

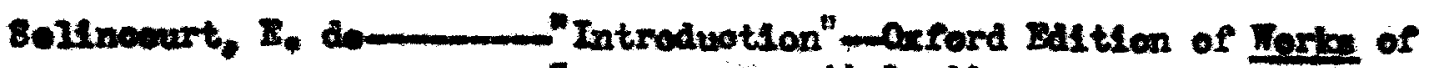
Sponear ip Fil-1ivit London-ciford Brivereity Prosem-10as

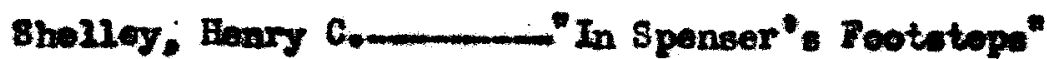

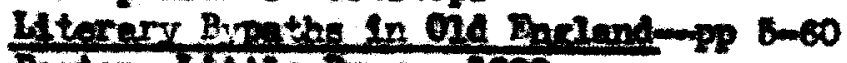

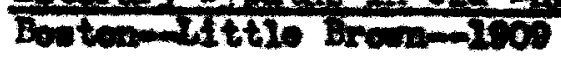

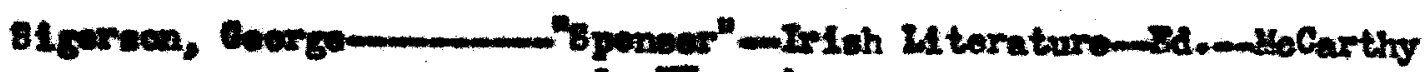
v1. I $\operatorname{lix}$

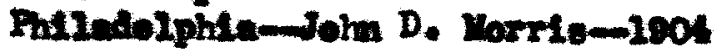




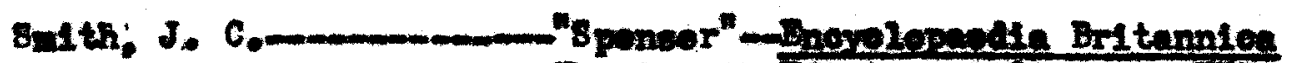 Fourtoonth EAltion-1820-rol. XI

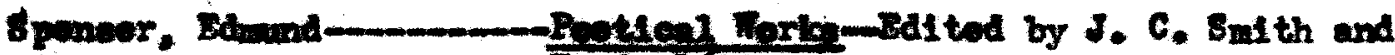 3. do 86Iinoeurt$$
\text { Londen-Oxford Dalweraity Prose-1029 }
$$

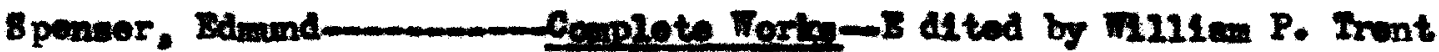 Fow York-crow11-1903

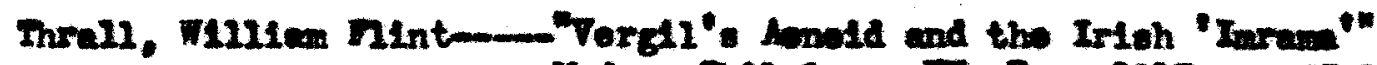

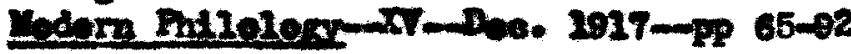

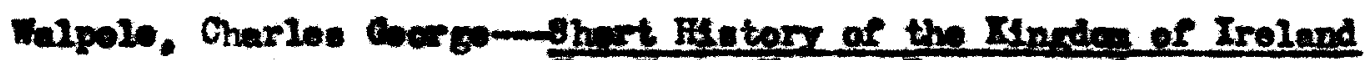

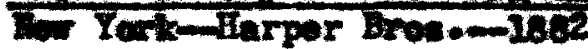

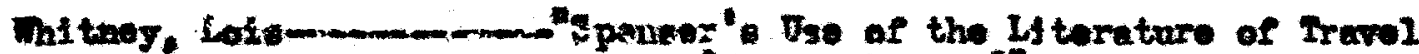 In the "Trovile Qwoen"

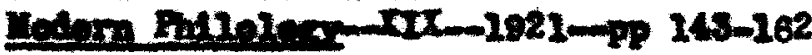

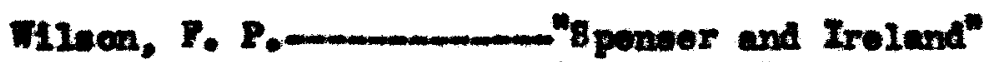

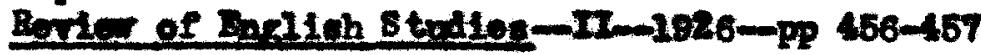

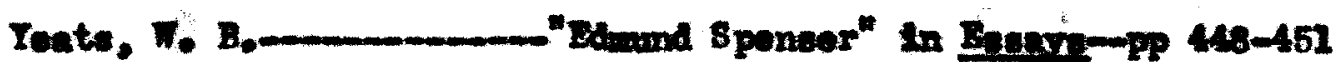 Ion Yort-ilacmillinom-102

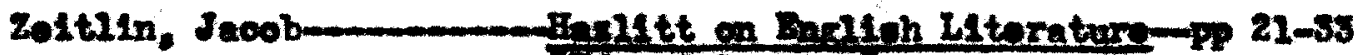 Lemen oponaer
No York-0xford Undversity Prowe-1913

